\title{
Review \\ Thermogenic Fat: Development, Physiological Function, and Therapeutic Potential
}

\author{
Bruna B. Brandão ${ }^{1,+}$, Ankita Poojari ${ }^{2,+}(\mathbb{D})$ and Atefeh Rabiee ${ }^{2, *}$ (i) \\ 1 Section of Integrative Physiology and Metabolism, Joslin Diabetes Center, Harvard Medical School, \\ Boston, MA 02215, USA; bruna.brasilbrandao@joslin.harvard.edu \\ 2 Department of Physiology \& Pharmacology, Thomas J. Long School of Pharmacy \& Health Sciences, \\ University of the Pacific, Stockton, CA 95211, USA; a_poojari@u.pacific.edu \\ * Correspondence: arabiee@pacific.edu \\ + These authors contributed equally to this work.
}

Citation: Brandão, B.B.; Poojari, A.; Rabiee, A. Thermogenic Fat: Development, Physiological Function, and Therapeutic Potential. Int. J. Mol. Sci. 2021, 22, 5906. https://doi.org/ $10.3390 /$ ijms 22115906

Academic Editor: Jean-François Tanti

Received: 14 April 2021

Accepted: 27 May 2021

Published: 31 May 2021

Publisher's Note: MDPI stays neutral with regard to jurisdictional claims in published maps and institutional affiliations.

Copyright: (c) 2021 by the authors. Licensee MDPI, Basel, Switzerland. This article is an open access article distributed under the terms and conditions of the Creative Commons Attribution (CC BY) license (https:// creativecommons.org/licenses/by/ $4.0 /)$.

\begin{abstract}
The concerning worldwide increase of obesity and chronic metabolic diseases, such as T2D, dyslipidemia, and cardiovascular disease, motivates further investigations into preventive and alternative therapeutic approaches. Over the past decade, there has been growing evidence that the formation and activation of thermogenic adipocytes (brown and beige) may serve as therapy to treat obesity and its associated diseases owing to its capacity to increase energy expenditure and to modulate circulating lipids and glucose levels. Thus, understanding the molecular mechanism of brown and beige adipocytes formation and activation will facilitate the development of strategies to combat metabolic disorders. Here, we provide a comprehensive overview of pathways and players involved in the development of brown and beige fat, as well as the role of thermogenic adipocytes in energy homeostasis and metabolism. Furthermore, we discuss the alterations in brown and beige adipose tissue function during obesity and explore the therapeutic potential of thermogenic activation to treat metabolic syndrome.
\end{abstract}

Keywords: adipose tissue; development; molecular circuits; secretome; thermogenesis; metabolism; obesity; therapy

\section{Introduction}

Obesity is the main driver of insulin resistance (IR), type two diabetes (T2D), and metabolic syndrome. Obese subjects, especially the ones with a high percentage of intraabdominal fat, have a greater risk of developing cardiovascular disease (CVD), the leading cause of death in industrial countries [1]. The prevalence of obesity is multifactorial and includes socioeconomic, educational status, issues concerning mental health, genetics, sedentarism, and diet [2]. It is now appreciated that obesity develops when energy consumption (food intake) overcomes energy expenditure. This induces white adipose tissue (WAT) expansion followed by reduced mass and activity of brown/beige adipocytes (fat cells), thereby contributing to the development of metabolic disorders during obesity [3].

WAT is the principal site for energy storage, while brown and beige adipocytes are the sites for energy expenditure (EE) due to their thermogenic capacity [4]. Adipose tissue (AT) is also an important endocrine organ responsible for the secretion of many molecules, including lipids [5,6], proteins [7-9], and miRNAs [10]. These factors serve as paracrineendocrine signals, critical for the function of AT itself, as well as non-adipose tissues, regulation of whole-body metabolism, and insulin sensitivity [11]. Therefore, interventions that can induce the formation and activation of brown and beige adipocytes such as cold exposure [12], pharmacological activation of the adrenergic pathways [13], or even genetic manipulation of adipocytes [14] are attractive therapies to improve metabolic health in obese humans. 


\section{Adipose Tissue Development and Origin}

Adipocytes are categorized as white or brown depending on their function and morphological characteristics. As an endocrine tissue responsible for hormonal secretion, WAT plays a role in fatty acid (FA) biosynthesis by storing triglyceride (TG), and it is composed of unilocular adipocytes containing a large lipid droplet. By comparison, brown adipose tissue (BAT) plays a role in glucose uptake and FA breakdown, leading to energy dissipation and heat production. Brown adipocytes are multilocular cells with central nuclei and mitochondria rich in the expression of uncoupling protein 1 (Ucp1) [15-17]. The primary function of BAT is non-shivering thermogenesis, an energy-intensive process in which chemical fuel is turned into physical heat. In addition to BAT, the process of thermogenesis can also be carried out by a third type of adipocytes known as beige adipocytes. Beige adipocytes share many of their morphological features with brown adipocytes namely the presence of multilocular lipid droplets and abundant mitochondria expressing Ucp $1[15,18]$. However, unlike brown adipocytes, which are committed to the process of thermogenesis, beige adipocytes are a form of thermogenic adipocytes that may be induced within WAT depots sporadically via a white-to-brown transition known as "browning". The extreme plasticity of beige adipocytes causes the browning process to be reversible and highly dependent on the continuation of energy imbalance caused by external cues. Interestingly, the induced beige adipocytes transition to their original white state soon after the energy balance is restored [19-24].

Even though WAT itself may be categorized broadly into two subtypes of visceral white adipose tissue (vWAT) and subcutaneous white adipose tissue (scWAT), beige adipocytes are mainly known to be induced within scWAT depots [16]. vWAT comprises perirenal (prvWAT), perigonadal (pgvWAT), mesenteric (mvWAT), and retroperitoneal (rpvWAT) white adipose tissues. In humans, there are scWAT depots in the cranial, nasal, gastrointestinal, femoral, and gluteal areas. Correspondingly, such scWAT depots are also found in rodents in the anterior subcutaneous white adipose tissues (ascWAT) and the posterior subcutaneous (pscWAT) which include inguinal, dorso-lumbal, and gluteal WAT $[15,25]$. Anatomically, BAT depots are dispersed in the scapulae (interscapular, cervical, and axillary) and thoracic (mediastinal) areas of mice and rats [26]. As opposed to the previously held view, that BAT is only present in the neck and shoulder regions of newborn children and infants [27], it has been widely proven by various studies, that active BAT depots with thermogenic capacity are found lying between anterior neck muscles and in the paracervical and supraclavicular regions of adult humans [27-31].

The timeline for the formation of BAT and WAT during embryogenesis also varies with the emergence and development of BAT occurring earlier in all mammalian species compared to WAT. In humans, BAT formation starts at the second gestational trimester where it is observed mainly in the head and neck and it later develops in the trunk, upper, and lower limb regions as well. In rodents, the formation of interscapular BAT occurs between E15-16 (embryonic phase) and increases postnatally between P15-21. Functional BAT formation with the ability to carry out thermogenesis is completed 2 days before birth during the E18-19 [32-35]. WAT development also occurs prenatally and the formation of both scWAT and vWAT is completed at the end of gestational weeks 23 and 28, respectively [36]. Unlike humans, wherein the formation of WAT is initiated and mostly completed in utero, for rodents, the development of scWAT and vWAT is mostly postnatal. vWAT formation commences after birth and scWAT formation is completed 56 days postpartum [37-39].

Brown and white AT originate and evolve from the mesoderm. vWAT arises from intermediate and lateral plate mesoderm [40-43], while BAT originates from paraxial mesoderm [44]. The origin of scWAT is still under dispute, with evidence indicating that the progenitor cells for this AT originate from both mesoderm and neuroectoderm [45-48]. Additionally, each type of fat depot consists of distinct and different precursor/progenitor populations that are regulated by various factors affected by age, gender, and environmental conditions. The recent advances in lineage tracing strategies, as well as gene expression 
studies, showed that white and brown adipocytes originate from different mesenchymal stem cells (MSCs). In brief, vWAT depots are largely derived from progenitors expressing Wilms tumor 1 (Wt1) $[42,49,50]$ and scWAT depots mainly originate from paired related homeobox 1 (Prx1) expressing progenitors [51-55]. Although in the past, it was believed that myogenic factor 5 (Myf5), paired box 3 (Pax3), and paired box 7 (Pax7) expressing progenitors were only responsible for the formation of BAT, it is now understood that scWAT depots of the dorsal-anterior body regions also partly share their origin with the above-listed progenitors $[17,47,56-59]$. Thus, it may be noted that even though adipocytes may develop from a common lineage, they may or may not have similar functions.

Several studies have noted that the existence of various cell surface markers may be used as a strategy to isolate beige and brown progenitors [60]. In humans, it was found that $\mathrm{Cd} 34+/ \mathrm{Cd} 31-$ and $\mathrm{Cd} 34+/ \mathrm{Cd} 146-/ \mathrm{Cd} 45-/ \mathrm{Cd} 56$ - cells were BAT progenitors in small vessels and fetal muscles, respectively [61]. Cd29+/Cd31-/Cd34-/Cd45- progenitor cells lead differentiation to the beige adipocytes within the scWAT depots of humans [62]. Moreover, beige adipocytes progenitors in mouse scWAT are marked by Cd81+/Sca1/Linand the Cd81+/Pdgf $\alpha+/$ Lin- mark the beige progenitors in human scWAT [63].

One can assume from these studies that $\mathrm{Cd} 34$ and $\mathrm{Cd} 81$ may be used as markers to identify brown and beige progenitors, respectively. However, isolation of different adipocytes based on such cell surface markers must be done cautiously considering factors such as the location of the depots within which the progenitors have resided and the effect of the surrounding microenvironment [64]. It is also known that adipocyte progenitors express platelet-derived growth factor receptors $\alpha(\operatorname{Pdgfr} \alpha)$ and $\beta(\operatorname{Pdgfr} \beta)$ [65]. In ex vivo studies, the presence of both Pdgfr $\alpha$ and Pdgfr $\beta$ in adipose stromal cells (ASCs) was confirmed [66]. However, in adult mice, the progenitors only expressed either Pdgfr $\alpha$ or $\operatorname{Pdgfr} \beta[67,68]$. Using Pdgfr $\alpha$ Cre recombinase mouse models, the existence of the Pdgfr $\alpha$ expressing cells during the normal establishment of WAT was shown. However, the existence of multiple Pdgfr $\alpha+$ populations that some of them are not adipogenic further indicates that Pdgfr $\alpha$ expression alone cannot be used to identify adipocyte progenitor populations within WAT [37]. Studies in humans and mice have confirmed that commitment towards either beige or white adipogenesis is predetermined by the balance between Pdgfr $\alpha$ and Pdgfr $\beta$ signaling in adipocyte progenitors, and a high level of Pdgfr $\alpha$ expression precedes ASCs differentiation into beige adipocytes. Moreover, in vitro studies showed that during the initial stages of adipocyte lineage development, $\operatorname{Pdgfr} \beta$ signaling promotes white adipogenesis, whereas Pdgfr $\alpha$ signaling is followed by brown adipogenesis [69]. As a result of impaired $\beta$-adrenergic signaling (a common cue for initiation of browning), a subset of Pdgfr $\alpha+/ \mathrm{Cd} 34+/ \mathrm{Cd} 29+$ progenitors in scWAT expresses myoblast determination protein (MyoD); which supports beige adipogenesis following cold acclimation. However, these MyoD derived beige adipocytes are different from standard beige adipocytes in terms of their developmental origin and their metabolism with these beige adipocytes having enhanced glucose metabolism and therefore, named as glycolytic beige adipocyte. It is now postulated that multiple subtypes of beige thermogenic adipocytes exist and their functions vary based on the nature of external stimuli, such as cold acclimation or diet [70].

\section{Molecular Circuits Regulating Brown and Beige Adipose Tissue Development and Function}

Adipocyte differentiation happens when multipotent stem cells commit to forming preadipocytes that further undergo terminal differentiation to form mature adipocytes. Despite the differences in developmental origins of brown and beige adipocytes, both cell types share a similar transcriptional cascade involving a distinct chromatin landscape governing a vast gene expression program that controls the process of fat differentiation. The chromatin landscape itself comprises an intricate and complex network of transcriptional regulators (transcription factors and cofactors), epigenetic factors (histone marks and chromatin methylation), and non-coding RNAs (long non-coding RNAs and microRNAs). 


\subsection{Transcriptional Regulation of Brown and Beige Adipocytes}

Transcription factors (TFs) are DNA binding proteins that activate or repress RNA polymerase II (Pol II)-mediated transcription. These proteins bind to DNA sequences at promoter or other regulatory regions such as enhancers. The core transcriptional machinery coordinated by peroxisome proliferator-activated receptor gamma (Ppar $\gamma$ ) and members of the $\mathrm{C} / \mathrm{ebp}$ family of transcription factors (TFs) governing the differentiation process of adipocytes are similar for all types of fat cells and have been extensively discussed elsewhere [16,71-73]. Various TFs, cofactors (corepressors and coactivators), and nuclear receptors (NRs) which regulate the process of white versus brown lineage commitment are already known and coordinate functionally in a concerted manner to modulate the principal adipogenic transcriptional machinery. Overall, the process of formation of beige and brown AT by TFs is mainly regulated via a two-fold mechanism, i.e., either activation of BAT and beige-selective genes or by suppressing WAT-specific genes. Here, we describe the main brown and beige fat-selective signatures of TFs.

Early $\beta$-cell factor 2 (Ebf2) is a marker of committed brown adipocytes that inhibits the expression of MyoD and muscle-specific transcription factor (myogenin) [33,74]. The high expression level of Ebf2 in adult human brown preadipocytes suggests its role in brown preadipocyte determination [75]. Ebf2 also promotes brown adipocytes differentiation by recruiting Ppary to its BAT-selective binding sites [74]. Ebf2 knockdown diminished the brown fat-specific features of BAT [74]. Besides, Ebf2 overexpression in WAT induces browning and thermogenesis [76].

Ewing sarcoma (Ews) regulates the expression of bone morphogenic protein 7 (Bmp7) and thereby plays an important role in the commitment of early mesenchymal progenitors to brown adipocytes. Ews is also involved in the differentiation process of BAT as the brown preadipocytes isolated from the newborn Ews null mice did not differentiate ex vivo. In addition, decreased number of multilocular lipid droplets and mitochondria, as well as reduced Ucp1 expression in the BAT of Ews null mice, indicates the critical role of Ews in brown fat phenotype and thermogenic function. Ews also plays role in the browning of WAT as the Ews heterozygous mice showed fewer beige cells formed in the WAT exposed to the browning stimuli such as Ppar $\gamma$ agonists and $\beta 3$-adrenergic stimulation [77]. The role of Ews in controlling the thermogenic function of beige and brown AT is proposed to be via stabilizing Pgc1 $\alpha$ [78].

$\mathrm{Y}$ box binding protein $1(\mathrm{Ybx} 1)$ is a cold shock domain protein that together with Ews regulates the Bmp7 expression through which plays a role in the commitment of precursor cells to BAT. In the same complex with Ews, Ybx1 also regulates the differentiation of brown preadipocytes [77]. We recently demonstrated a critical role of Ybx1 in priming and maintaining the thermogenic capacity during adipogenesis [79].

Heat shock factor 1 (Hsf1) deficient mice are more sensitive to low temperatures, reduced Ucp1 expression in scWAT and BAT, and decreased thermogenesis and $\beta$-oxidation indicating an overall reduced brown and beige tissue functionality [80,81].

TATA-binding protein-associated factor 7L (Taf7l), the study by Zhou et al. performed in mice as well as in cell lines introduced the Taf7l as a commitment factor that enhances the brown fat lineage as compared to muscle. Taf7l mediates the loop formation in chromatin bringing together the distal enhancer regions and the promoters, and in that way controls the expression of BAT-selective genes [82].

Zinc finger in the cerebellum 1 (Zic1) has been described with a controversial role in beige and BAT formation. Overexpression of Zic1 in C3H10T1/2 mouse MSCs attenuated the expression of BAT-selective genes and increased the expression of myogenic genes [83]. In mice, however, the expression of Zic1 mRNA was increased in WAT with cold-induced browning [84].

Zinc finger and BTB domain-containing protein 16 (Zbtb16/Zfp14) is increased in BAT during adaptive thermogenesis in mice $[85,86]$ and also promotes the WAT browning and thermogenic function in vitro in cells. 
Zinc finger protein 238 (Zfp238) expression is induced upon $\beta$-adrenergic stimulation in scWAT of mice. Zfp238 suppresses the inhibitory role of Foxo1 and increases the expression of thermogenic genes. The adipose-specific Zfp238 KO mice and 3T3-L1 cells significantly decreased Ucp1 expression [87].

PR domain zinc finger 16 (Prdm16) is a TF promoting brown and beige adipocyte differentiation and repressing the myogenic program [56,88]. The role of Prdm16 in initiating the brown/beige program versus myogenic is fulfilled by being in the same complex with histone methyltransferase Ehmt1 with its inhibitory role on the myogenic program [89]. The role of Prdm16 in inhibiting the WAT gene expression is via interacting with carboxy-terminal binding proteins, Ctbp1 and Ctbp2 co-repressor complexes [90]. Lacking Prdm16 in Myf5 positive progenitors does not affect BAT and beige development, due to the potential compensatory role of Prdm3 [91]. In the same complex with C/ebp $\beta$ and Ppary, Prdm16 functions to promote brown/beige adipogenesis [56,92]. In addition to its role in determining brown/beige fat identity and adipogenesis, Prdm16 is also important in maintaining the brown fat identity by binding to the enhances of brown-selective genes and working together with the mediator complex to establish an enhancer-promoter loop leading to the expression of Ppar $\alpha$ and Pgc1 $\alpha$ [93]. Moreover, Prdm16 directly interacts with Pgc1 $\alpha$ and induces its transcription $[88,91,94]$. Prdm16 also inhibits the signaling of repressor type 1 interferon response genes thereby preventing mitochondrial dysfunction and reduced Ucp1 levels [95]. Prdm16 regulates the browning of WAT as its overexpression increases beige adipocytes and thermogenesis in WAT while its deficiency inhibits beige adipocyte formation $[96,97]$.

PR domain zinc finger 3 (Prdm3) has a complementary role to Prdm16 especially during early developmental stages in mice and, interacts with mediator complex subunit 1 (Med1) at chromatin level to regulate the brown-specific program. As a commitment factor, Prdm3 also induces the expression of Ucp1 and Pgc1 $\alpha$ in C2C12 myogenic cells [91,93].

Ppar $\gamma$ co-activator 1A (Pgc1 $\alpha$ ) plays a crucial role in cold-induced thermogenesis and thermogenic maintenance in differentiated brown and beige adipocytes. Pgc1 $\alpha$ expression is highly induced in response to the cold and upon its further activation after being phosphorylated as a downstream target of the cAMP pathway, Pgc1 $\alpha$ interacts with several TRs including Prdm16 and Ppar $\gamma$ and activates the thermogenic genes [98,99]. Among others, the Pgc1 $\alpha$-Irf4 complex regulates the Ucp1 gene expression [100], the complex formed by thyroid hormone receptor (TR), Pgc1 $\alpha$, Prdm16, and Med1 also activates Ucp1 transcription $[94,101]$. The complex formed by Pgc1 $\alpha$ and nuclear respiratory factors, Nrf1 and Nrf2, promotes the activation of several mitochondrial genes [102]. Pgc1 $\alpha$ overexpression induces the thermogenesis in adipocytes and myocytes $[103,104]$. Brown adipocytes lacking Pgc1 $\alpha$ express almost the same level of Ucp 1 and other thermogenic genes, however, show a lower level of Ucp1 expression in response to the adrenergic stimuli $[105,106]$. Pgc1 $\alpha$ is also required for the browning of WAT [107].

Interferon regulatory factor 4 (Irf4) interacts with Pgc1 $\alpha$ upon cold stimuli and regulates the expression of Ucp 1 through binding to its regulatory regions on the chromatin [100].

Zinc finger protein 516 (Zfp516) also increases brown adipogenesis as well as thermogenesis upon cold induction by interacting with Prdm16 which activates Ucp1 and Pgc1 $\alpha$ gene expression [108].

cAMP-responsive element-binding and activating transcription factor 2 (Creb-Atf2); cold induction increases the adrenergic pathways as well as the intracellular levels of cAMP. This leads to PKA-dependent phosphorylation and activation of Creb and Atf2 which will further result in activation of Ucp1 and Pgc1 $\alpha$ gene expression [109].

Forkhead box protein C2 (Foxc2) expression increases beige adipocyte formation by promoting the protein kinase A (PKA) activity that is a main downstream kinase activated by adrenergic pathway upon cold induction [110]. The Foxc2 transgenic mice that show increased mitochondrial number and respiration in scWAT do not gain weight on the 
high-fat diet (HFD) as compared to the control mice. Moreover, the expression of Foxc2 in 3T3-L1 cells inhibits adipogenesis by blocking the Ppary expression [111].

Krüppel-like factor 11 (Klf11) expression is induced in vitro in human white adipocytes in response to Ppar $\gamma$ agonist, rosiglitazone, and via maintaining the association of Ppar $\gamma$ with super-enhancers of beige-selective genes, Klf11 promotes beige adipocyte-selective gene expression [112].

Krüppel-like factor 9 (Klf9) in vitro and in vivo in mice regulates the cold-induced browning of WAT and thermogenic function of AT through enhancing the Pgc1 $\alpha$ expression [113].

GA-binding protein $\alpha(\mathrm{Gabp} \alpha)$ is the TF expressed in myoblasts that inhibits myogenesis and promotes adipogenesis and beige fat development. In vitro, in C2C12 myoblasts, Gabp $\alpha$ expression increased beige adipogenesis to the levels comparable to Prdm16. The interaction between Pgc1 $\alpha$ and Gabp $\alpha$ is also shown to stimulate mitochondrial biogenesis and the OXPHOS (mitochondrial oxidative phosphorylation) program [114-116]. Gabp $\alpha$ expressing beige adipocytes unlike other beige adipocytes have a higher glucose oxidation rate than FA oxidation [70].

Nuclear receptors including the Reverb $\alpha$ [117,118], Err $\alpha$ [119], Err $\gamma$ [119], Rxr $\alpha$ [120], and Nur77 [121] have been described to positively regulate the brown and beige adipose development and function.

Several TFs and activating cofactors are shown to have negative effects on beige/brown fat formation and function including Hes1 [122], Irx3 [123], Irx5 [123], Rip140 [124-126], Tle3 [127], Zfp423 [128,129], Hoxc8 [130], Hoxc10 [131], Twist1 [132], Foxa3 [133,134], Foxo1 [135,136], Foxp1 [137], Rb [138], Src2 (Tif2), Smad3 [139], Usf1 [140], Mrtfa [141], Lxr [142], and P107 [143-145]. Transcriptional repressors such as Ctbp1 and Ctbp2 [90,146] suppress the WAT gene expression and promote the browning of WAT.

\subsection{Epigenetic Regulation of Brown and Beige Adipocytes}

Epigenetic regulation is a heritable mechanism that includes DNA modifications, mainly DNA methylation, and histone modifications altering gene transcription without changes in DNA sequence. The chromatin landscape governs brown/beige differentiation and commitment, and its activation is regulated by a tight collaboration between TFs and epigenetic modifiers.

Chromatin immunoprecipitation (ChIP) of Ppar $\gamma$, the master regulator of adipogenesis, combined with deep sequencing (ChIP-seq) analysis revealed that up to $55 \%$ of Ppar $\gamma$ binding sites are similar among the prevalent fat types, i.e., BAT, scWAT, and vWAT with only $10 \%$ of the Ppar $\gamma$ binding sites being specific to BAT. Moreover, only a $10 \%$ difference in the Ppar $\gamma$ binding sites was recognized in BAT versus WAT upon rosiglitazone (PPAR $\gamma$ agonist) treatment, further confirming that beige and brown AT characteristics are acquired from small specificity of the chromatin landscape $[74,112,147]$. Using transgenic nuclear tagging and translating ribosome affinity purification, NuTRAP mice, and NuTRAP reporters in adipocytes, the transcriptomic and epigenomic profiles of beige, brown, and white adipocytes are defined in vivo. These strategies further confirmed the stability of chromatin landscape in BAT and the plasticity of beige adipocytes upon temperature change [148].

The enrichment of active histone marks such as H3K4me1/2/3 and H3K27ac at DNA regulatory regions (promoter and enhancer) promotes the expression of nearby genes. Contrarily, the recruitment of repressive histone marks, such as H3K27ac, H3K27me3, H4K20me3 to DNA regulatory regions suppresses the gene expression. Active histone marks such as H3K4me1/2 and H3K27ac are enriched in BAT and not WAT lineage enhancers [149]. Ucp1 promoters in BAT are enriched in active histone mark H3K4me3, and in WAT are enriched in H3K27me3 repressive mark [150]. The expression of repressive histone marks is diminished upon cold induction in brown adipocytes [151]. Overall, the recruitment of active histone marks to the regulatory regions of BAT-selective genes seems to play an important role in the expression of these genes. 
Several histone methyltransferases and demethylases have been identified to regulate the chromatin landscape in brown fat through alteration of the active and repressive histone marks [152,153]. For instance, the ubiquitously transcribed tetratricopeptide repeat on chromosome X (Utx) through coordinated regulation of H3K27me3 demethylation and H3K27 acetylation switches the transcriptionally repressive to the active state at the promoters of Ucp1 and Pgc1 $\alpha$, thereby positively modulating BAT thermogenesis $[150,154]$. Additionally, demethylation of $\mathrm{H} 3 \mathrm{~K} 27 \mathrm{me} 3$ by Jmjd3 is also necessary for the expression of BAT-selective genes and for the development of beige adipocytes both in vitro and in vivo [150]. In response to acute cAMP stimuli, jumonji domain-containing 1A (Jmjd1a) demethylates the repressive H3K27me3 in brown adipocytes and regulates the Ucp1 gene expression [155]. Lysine-specific histone demethylase 1 (Lsd1), through interaction with Zfp516 (brown fat-enriched and cold-inducible TF), is recruited to Ucp1 and other BAT-selective genes such as Pgc1 $\alpha$, to work as a coactivator by demethylating H3K9 [156]. Mll4/Kmt2d co-localizes with lineage-determining TFs on active enhancers and its deletion significantly reduces the H3K4me1/2 active histone mark and polymerase II levels on enhancers which consequently impairs brown adipogenesis in mice [157]. Euchromatic histone-lysine $\mathrm{N}$-methyltransferase 1 (Ehmt1) is a BAT enriched methyltransferase that controls brown adipose cell fate and its loss in brown adipocytes in vivo diminishes brown fat characteristics and induces muscle differentiation through demethylation of histone 3 lysine 9 of the muscle-selective genes [89]. Histone deacetylase 3 (Hdac3) activates estrogen-related receptor $\alpha(E r r \alpha)$ in BAT, which itself is governed by deacetylation of $\operatorname{Pgc} 1 \alpha$ and is essential for the transcription of Ucp1, Pgc1 $\alpha$, and OXPHOS genes which are engaged and necessary for thermogenic programming [158]. Kmt5c methyltransferase regulates the expression of thermogenic genes by increasing the H4K20me3 repressive mark in the vicinity of enhanced transformation-related protein 53 (Trp53) promoters [159].

Brahma homolog related gene 1 (Brg1), a member of the SWI/SNF family plays a central role for thermogenesis on $\beta$-adrenergic activation by forming a complex with Jmjd1a and Ppary; wherein this complex enhances Ucp1 expression by facilitating the enhancerpromoter chromatin looping [155]. Additional roles of histone modifiers, including histone acetyltransferases (Hats), histone deacetylases (Hdacs), histone methyltransferases (Hmts), and histone demethylases have been comprehensively reviewed by Nanduri [160].

The role of DNA (de)methylation events in beige and brown AT development and function are well discussed by others [161]. Several genes including members of the Hox family genes are identified to be differentially methylated between white and brown fat tissue implying the role of methylation in lineage specificity [162]. DNA methylation at CG sites on the Ucp1 enhancer regions is decreased with cold-induced browning in WAT. DNA methylation inhibitor, 5-azacytidine, increases the expression of Hox genes (mainly Hoxc10), thereby suppressing the browning of WAT [131,162]. In mice, Dnmt1 expression leads to the development of brown fat versus muscle by increasing the DNA methylation at the MyoD1 promoter and thereby inhibiting the expression of the muscle-specific gene, MyoD1 [163]. DNA demethylase ten-eleven translocation 1 (Tet1) inhibits the thermogenic function of BAT by suppressing the thermogenic gene, Hdac1. The expression of Tet1 is decreased with cold-induced browning of scWAT in mice, and the Tet1-KO in WAT showed enhanced thermogenic function in adipocytes as measured by the expression of the thermogenic genes including Ucp1 and Pgc1 $\alpha$ [164].

\subsection{Non-Coding RNAs}

In addition to TFs and epigenetic regulation, non-coding RNAs including microRNAs (miRNAs) and long-noncoding RNAs (lncRNAs) have been found to play important roles in beige and brown fat commitment, differentiation, and function either by repressing or inducing the expression of genes involved in these processes. 


\subsubsection{MicroRNAs (miRNAs)}

MicroRNAs (miRNAs) are small (21 to 25 nucleotides) non-coding RNAs, fundamental to the regulation of gene expression. They are processed by RNase III enzymes, Drosha and Dicer, in the nucleus and cytoplasm respectively. In the cytoplasm, the mature miRNA is loaded into the RNA-induced silencing complex (RISC), which contains Argonaute 2 (AGO2), the protein responsible for guiding the mature miRNA to its target mRNA. Once the miRNA-RISC complex binds to its target mRNA, translation is inhibited and, in some cases, mRNA is destabilized and degraded [165]. The importance of this pathway to adipocyte differentiation and function is evidenced by in vivo studies where deletion of AT Dicer or the Drosha's cofactor, Dgcr8, almost completely ablated the production of mature miRNAs in the targeted cell, and altered WAT and BAT distribution, morphology and function [166]. Additionally, studies have also evaluated the contribution of individual miRNAs and described their role in beige and brown fat formation and function [167]. For instance, miR-133 represses the adipogenic lineage commitment of satellite cells by decreasing the expression of Prdm16. During cold exposure, miR-133 is downregulated leading to satellite cell-derived brown adipocytes [168]. On the other hand, miR-328 and miR-193b induce brown adipogenesis and block muscle progenitor commitment, in part, through downregulation of $\beta$-secretase Bace1 [169]. Moreover, miR-30 was shown to regulate browning of WAT, and the thermogenic function of beige and brown adipocytes by targeting Rip140, a known thermogenic corepressor [170].

\subsubsection{Long Non-Coding RNAs (lncRNAs)}

The molecular regulation by RNAs is not limited to small RNAs and increasing evidence has suggested that long non-coding RNAs (lncRNAs) also play a role in beige and brown development and function [171]. LncRNAs are RNA molecules with more than 200 nucleotides in length and their mechanism of action includes chromatin remodeling, chromatin interactions, natural antisense transcripts (NATs], as well as interacting with RNA binding proteins in the cytosol [172]. Studies evaluating the role of lncRNAs in beige and brown fat formation and thermogenesis have observed the interaction of the lncRNABlnc1 with the TF of Ebf2 and the zinc finger protein Zbtb7b. Mechanistically, these factors form a ribonucleoprotein complex with lncRNA-Blnc1 and stimulate a thermogenic gene program in beige and brown adipocytes [173-175]. The lncRNA-BATE1 was also shown to positively regulate the beige and BAT formation. In the cytosol, IncRNA-BATE1 binds to the RNA binding protein Celf1, which is known to bind to the Pgc1 $\alpha$ mRNA inducing its degeneration and suppressing its translation [176].

\section{Thermogenesis Pathways and Players}

The browning process involves trans-differentiation of mature white adipocytes or de novo adipogenesis of beige adipocytes. It can be induced by adrenergic stimuli, HFD feeding, and cold exposure [177-180]. This de novo adipogenesis process involves proliferation and differentiation of beige adipocytes from its progenitor pool which are present in adipose vasculature mural cells as well as smooth muscle cells that express smooth muscle actin (Sma), Myh-11, or Pdgfr $\alpha$ [181]. Another contribution to the overall beige fat content is by activation of dormant beige adipocytes which is also considered a transdifferentiation process as no intermediate progenitors are involved [21,67,180,182-185]. While current tracing technologies are unable of distinguishing between white to beige adipocyte trans-differentiation and the activation of dormant beige cells, Sebo and Rodeheffer have extensively discussed existing strategies available for lineage segregation of adipocytes [186].

Initiation of various signaling processes in AT may lead to thermogenic activation of BAT and browning of WAT. Several receptors on AT play a central role in such pathways leading to the increased thermogenic function of adipocytes. The physiological ligands for such receptors on adipocytes are either adipokines secreted by AT itself [187-189] or factors released from the various organs in response to environmental challenges such as cold, 
fasting, feeding, and exercise [190]. Here, we summarize the main signaling pathways described in WAT browning and thermogenic activation.

\subsection{Adrenergic Signaling}

$\mathrm{ADR} \beta 3$ is the main receptor on AT involved in adrenergic pathways related to adaptive thermogenesis in brown or beige adipocytes. Norepinephrine (NE) released from the sympathetic nervous system (SNS) and M2 macrophages [188,191,192] is the primary ligand of ADR $\beta 3$ that upon binding activates the protein kinase A (PKA) and subsequently activates the p38 MAPK and thyroxine 5 '-deiodinase leading to the induction of thermogenic gene program $[137,193,194]$.

\subsection{Thyroid Hormone (TH) Signaling}

The main TH receptors in adipocytes are TH receptor $\alpha(\mathrm{TR} \alpha)$ that mediates synergistic effects of TH signaling and SNS, TH receptor $\beta$ (TR $\beta$ ) that modulates the expression of Ucp1. During the thermogenic adaptation, the thyroxine (T4) released from the hypothalamicpituitary-thyroid axis after entering the AT will be converted into the triiodothyronine (T3) by type II thyroxine 5'-deiodinase (Dio2), an enzyme controlled by NE. Besides, TH affects the hypothalamus and promotes the AMP-kinase induction, and enhances the SNS function of NE production, leading to an increased thermogenic function [195].

\subsection{Bile Acid Signaling}

The main bile acid receptor on AT is the G-protein-coupled bile acid receptor, Gpbar1 (TGR5). It has been shown that the bile acids released from the liver after a meal and bound to the TGR5 receptors on AT also contribute to the regulation of Dio2 expression by increasing the levels of cAMP [196]. TGR5 signaling induces the WAT browning and thermogenesis by increasing lipolysis, free fatty acids (FFAs) production, and $\beta$ oxidation. TGR5 signaling also increases the number of mitochondria by inducing the mitochondrial fission (separates one into two) through the Erk/Drp1 pathway, further improving mitochondrial respiration [197].

\subsection{Angiotensin II Signaling}

The primary angiotensin II (AngII) receptors in AT are angiotensin type 1 or type 2 receptors (AT1R and AT2R). AT is a major source of AngII and, indicating the autocrine and paracrine role of AngII in regulating adipose functions and self-remodeling. The in vitro study conducted in mouse and human primary adipocytes showed that activation of AT2R increases the WAT browning and brown adipogenesis by increasing the Ppar $\gamma$ expression, as well as enhancing the Erk1/2, PI3kinase/Akt, and AMPK signaling pathways. In mice, AngII also contributes to the browning of WAT and enhanced thermogenesis by increasing the adiponectin release and decreasing the levels of TNF $\alpha$, TGs, and FFAs in blood serum [198].

\subsection{Fibroblast Growth Factors ( $F g f$ ) Signaling}

The Fgf receptor (FgfR)/b-Klotho complexes are also located on the adipocytes cell surface in mice and humans. The main Fgfs regulating the BAT activity and WAT browning include Fgf15, Fgf19, and Fgf21 secreted from the liver, and Fgf6\& Fgf9 released from the BAT. The main action of Fgf21 is conducted by inducing the expression of Pgc1 $\alpha$, Fgf6, and Fgf9 that involve Fgf receptor-3 (FgfR3), prostaglandin-E2, and interaction between estrogen receptor-related alpha, flightless-1 (FIII), and leucine-rich-repeat-(in FIII)-interacting-protein-1 as a regulatory complex for Ucp1 transcription. Fgf15 and Fgf19 increase the blood levels of Cxcl14 which is a batokine regulating the Ucp1 expression and thermogenesis [199-201]. 


\subsection{BMP Signaling}

BMP signaling relies on the binding of BMPs to type I and II BMP receptors on AT. The main BMPs regulating the thermogenic commitment and activity of beige and brown AT include BMP4, BMP7, and BMP-8b. Although BMPs are mainly known as adipokines, the precise source of BMP's secretion remains elusive. BMP- $8 \mathrm{~b}$ is a batokine induced by nutritional and thermogenic factors in mature BAT which increases the thermogenic activity of BAT by; I) increasing the p38 MAPK/Creb signaling and sensitizing the BAT to NE, and II) acting on the hypothalamus increasing the AMP-activated protein kinase (AMPK) phosphorylation, leading to an anorexigenic state. BMP4 and BMP7 increase the Ucp1 expression and mitochondrial biogenesis via a p38 MAPK and Pgc1 $\alpha$ dependent pathway [202-204].

\subsection{Natriuretic Peptides (NPs) Signaling}

NPs are mainly released from the heart and bind to the natriuretic peptide receptors (NPRs) on the AT. Activating the cGMP-dependent protein kinase (PKG), the action of NPs is additive to the effects of adrenergic signaling leading to BAT activation and browning of WAT [205-207].

\subsection{Irisin Signaling Pathway}

In rodents and humans, exercise enhances the release of the irisin from the muscle. Although the irisin receptors in fat are still debated, the irisin-induced thermogenic gene program was shown to be mediated via the integrin $\alpha \mathrm{V}$ family of receptors. Irisin expression in muscle is regulated by Pgc1 $\alpha$ expression. In AT, irisin induces the WAT browning and enhances the thermogenic activity of BAT $[208,209]$.

\section{Brown and Beige Adipose Tissue Function}

Due to differences in the makeup and location of the fat itself, both brown and beige fat depots differ from white fat in terms of their physiological function, especially in terms of energy homeostasis and their secretory role. White fat is known to play a major role in FA biosynthesis and store energy in the form of TG whereas brown and beige fat are the important players in the process of heat dissipation/energy expenditure [210-212]. These contradictory roles among different types of fat can be partly attributed to the difference in the mitochondrial proteome and lipid composition discussed below.

\subsection{Role of Brown and Beige Fat in Thermoregulation}

Unless exposed to extreme conditions or fluctuating temperatures, mammals can keep their body temperature within a narrow range which is critical for the survival of these species as the critical biochemical reactions that occur under normal physiological conditions are affected when core body temperature is disrupted [213]. Brown and beige fat are important organs involved in thermoregulation. For instance, when humans are exposed to colder temperatures, BAT mass and activity are increased resulting in increased cold tolerance [214-216]. On the other hand, removal of BAT and beige AT in mice using genetic approaches leads to fatal hypothermia when these mice are exposed to cold [217].

At the cellular level, brown and beige adipocyte mitochondria are rich in proteins involved in the tricarboxylic acid cycle (TCA), electron transport chain complexes I-IV, and FA oxidation [218]. The main characteristic of both brown and beige adipocytes is the presence of Ucp1 at the inner membrane of mitochondria [219]. Thermogenesis occurs when Ucp1 uncouples the proton motive force of the respiratory chain. Under normal conditions, the electron transport chain generates a proton gradient in the inner mitochondrial membrane which powers ATP production by ATPase. When Ucp1 is active, it transfers the protons generated from the electron transport chain back across this membrane, dissipating the electrochemical gradient. Oxidative metabolism that is required to maintain the normal function of the cells consumes calories and leads to an increased temperature of the cells [220]. Thermogenesis by its nature is an energy-intensive process that upon 
activation increases the whole-body EE. To sustain this process, activated brown and beige fat depots require a continuous supply of substrates in the form of glucose, FFAs, and intracellular TGs. This directly contributes to reduced blood glucose, improved insulin sensitivity, TG serum clearance, loss of body fat, and consequently a general improved metabolic health [221-223].

Although Ucp1 mediated energy dissipation and its role in metabolism and thermoregulation have been most widely discussed in the literature, it is now understood that several other thermogenic mechanisms also exist. For example, at thermoneutral temperature, deletion of Ucp1 has no effect on EE or weight gain when mice are submitted to HFD [224-228]. When exposed to cold, Ucp1-/- gradually adapt to the temperature and maintain their normal body temperature [108,229-232].

Though these Ucp1 independent mechanisms are predominantly studied in beige AT, they have also been detected in classic brown AT [233]. Some Ucp1 independent thermogenic pathways include; (I) the endogenous uncoupler peptidase M20 domain containing 1 (Pm20d1) which produces $N$ - acyl amino acid and independent from Ucp1 increases mitochondrial respiration and brown and beige fat thermogenesis [234], (II) Slc25a25 which transports ATP- $\mathrm{Mg}^{2+} / \mathrm{P}[\mathrm{i})$ across the mitochondrial inner membrane and produces heat independent from Ucp1 [235], (III) the ADP / ATP carrier (AAC) in mitochondrial inner membrane mediates the proton leak from the intermembrane mitochondrial space to the matrix and dissipates the energy in the form of heat [236], (IV) the futile creatine cycle also is known to dissipate the energy and produce heat in response to cold or $\beta$-adrenergic activation in mice and humans and inactivation of this cycle reduces the thermogenic potential [237-240], (V) the futile cycling of lipolysis/re-esterification in which ATP is used to produce the triacylglycerols, diacylglycerols, or monoacylglycerols from acylglycerol is Ucp1-independent and is activated in response to adrenergic stimuli in WAT and BAT [241,242], (VI) the ATP-dependent $\mathrm{Ca}^{2+}$ cycling via Sarco/endoplasmic reticulum $\mathrm{Ca}^{2+}$-ATPase2b (Serca2b) and ryanodine receptor 2 (Ryr2) is also an Ucp1-independent thermogenic pathway. The activation of $\alpha 1 / \beta 3$-adrenergic receptors or the Serca2b-Ryr2 pathway enhances the $\mathrm{Ca}^{2+}$ cycling thereby, increases the Ucp1 independent thermogenesis [243,244], and (VII) the increase of adenine nucleotide translocase 2 (Ant2), an inner mitochondrial membrane, caused by high-fat diet feeding increases the protons leak and promotes diet-induced thermogenesis independent from Ucp1 [245,246].

\subsection{Glucose and Lipid Metabolism by Brown and Beige Fat}

In addition to endogenous TG breakdown, circulating TG-rich lipoproteins are hydrolyzed by lipoprotein lipase ( $\mathrm{Lpl}$ ) and FFAs are taken up through transporters such as Fatp1 and Cd36 to meet the high supply of fuel demand for thermogenesis [247,248]. Moreover, FFAs derived from WAT are also taken up by BAT via insulin-mediated translocation of the above-mentioned FA transporters [249]. Paradoxically, mild cold exposure induces de novo lipogenesis (DNL) and this is required for optimum BAT function. This counterintuitive mechanism is believed to be important to restore lipid droplets and may contribute to the synthesis of signaling lipids. Furthermore, enhanced DNL is known to increase the levels of cellular acetyl-CoA and malonyl-CoA, which can be a source of acetyl groups for protein lysine acetylation. This in turn may regulate epigenetic signals in BAT to sustain thermogenesis [250].

BAT and beige activation also increase insulin-independent glucose uptake, mediated by AMPK pathway and the glucose transporters Glut1 and Glut4. This leads to the hypothesis that thermogenesis activation may be used as therapy for insulin resistance and diabetes, which will be discussed later. In the cell, glucose will be utilized by the DNL pathway [251,252], stored as glycogen, or oxidized in the TCA cycle to feed the electric transport chain during thermogenesis activation [253]. 


\subsection{Secretory Role of Brown and Beige Adipose Tissue}

WAT is well known for its endocrine function due to the secretion of signaling molecules, so-called adipokines. These include leptin and adiponectin, and their impact on metabolism and appetite-control have been well studied. However, this secretory activity is not limited to white fat and intensive research is being carried out to gain information regarding brown and beige secretome [254,255]. Brown and beige fat are already known to release hormonal factors such as peptides (adipokines), lipids (oxylipokines), and exosomal miRNAs collectively termed as "batokines" which have autocrine, paracrine, and endocrine functions and are responsible for various processes within the human body such as EE, appetite control, lipid and glucose metabolism, insulin sensitivity, inflammation and tissue repair [256-258]. The secretory activity of brown and beige fat is complementary to the process of thermogenesis itself leading to further recruitment and activation of these fats. For most of the paracrine factors released from these thermogenic adipocytes, they act on cells present within the BAT such as preadipocytes, M2 macrophages, and endothelial cells consequently leading to differentiation and formation of mature adipocytes as well as increased vascularity. This intercellular communication is required for an efficient thermogenic process. There is still an ongoing debate as to how the secretory profile of beige AT differs from BAT as well as its implications. Moreover, some of the factors released by BAT have already been known to be majorly secreted by some other organs, causing an extra layer of complexity assigning an autocrine/paracrine/endocrine function to beige or brown AT.

A complete secretory profile of brown and beige fat might potentially play a role in designing therapeutic interventions for the maintenance of metabolic health. Some of these factors within the categories mentioned above and their known biological functions are disclosed in Table 1.

Table 1. Secretory profile of brown and beige adipose tissue.

\begin{tabular}{|c|c|c|c|c|c|c|c|c|c|}
\hline \multirow{2}{*}{ Type of Secretion } & \multicolumn{3}{|c|}{ Physiological Function } & \multicolumn{2}{|c|}{$\begin{array}{l}\text { Secreted by BAT/Beige } \\
\text { In Vivo }\end{array}$} & \multirow{2}{*}{$\begin{array}{l}\text { Secreted by } \\
\text { BAT/Beige } \\
\text { In Vitro }\end{array}$} & \multirow{2}{*}{$\begin{array}{l}\text { Overall } \\
\text { Thermogenic } \\
\text { Effect }\end{array}$} & \multirow{2}{*}{$\begin{array}{l}\text { Target } \\
\text { Organs }\end{array}$} & \multirow{2}{*}{ References } \\
\hline & Autocrine & Paracrine & Endocrine & Humans & Rodents & & & & \\
\hline \multicolumn{10}{|c|}{ (a) Factors Released for Substrate Utilization (Lipids) } \\
\hline $\begin{array}{l}\text { (1) 12,13-Dihydroxy-9Z- } \\
\text { Octadecenoic Acid } \\
\text { (12,13-diHOME) }\end{array}$ & YES & N/A & YES & Brown & Brown & YES & Positive & BAT, SM, H & [259-263] \\
\hline $\begin{array}{c}\text { (2) } 12 \text {-hydroxyeicosa } \\
\text { pentaenoic acid (12-HEPA) }\end{array}$ & YES & YES & YES & Brown & Brown & YES & Positive & SM, BAT & {$[259,264]$} \\
\hline $\begin{array}{l}\text { (3) 14-hydroxydocosahexanoic } \\
\text { acid (14-HDHA) }\end{array}$ & YES & N/A & $\mathrm{N} / \mathrm{A}$ & Brown & Brown & YES & Positive & BAT & [264] \\
\hline (4) Prostaglandins (PGs) & YES & $\mathrm{N} / \mathrm{A}$ & YES & Brown & $\begin{array}{l}\text { Brown/ } \\
\text { beige }\end{array}$ & $\mathrm{N} / \mathrm{A}$ & Positive & WAT, BAT & [265-268] \\
\hline \multicolumn{10}{|c|}{ (b) Factors Released for Vascular Regulation } \\
\hline $\begin{array}{l}\text { (1) Vascular endothelial } \\
\text { growth factor A (VEGF-A) }\end{array}$ & YES & YES & $\mathrm{N} / \mathrm{A}$ & $\mathrm{N} / \mathrm{A}$ & $\begin{array}{l}\text { Brown/ } \\
\text { beige }\end{array}$ & $\mathrm{N} / \mathrm{A}$ & Positive & $\begin{array}{l}\text { BAT, } \\
\text { WAT }\end{array}$ & [269-272] \\
\hline (2) Nitric oxide (NO) & YES & YES & $\mathrm{N} / \mathrm{A}$ & N/A & $\begin{array}{l}\text { Brown/ } \\
\text { beige }\end{array}$ & $\mathrm{N} / \mathrm{A}$ & Positive & $\begin{array}{l}\text { BAT, } \\
\text { WAT }\end{array}$ & {$[273,274]$} \\
\hline $\begin{array}{l}\text { (3) Hydrogen } \\
\text { peroxide }(\mathrm{H} 2 \mathrm{O} 2)\end{array}$ & YES & YES & $\mathrm{N} / \mathrm{A}$ & $\mathrm{N} / \mathrm{A}$ & $\begin{array}{l}\text { Brown/ } \\
\text { beige }\end{array}$ & $\mathrm{N} / \mathrm{A}$ & Positive & $\begin{array}{l}\text { BAT, } \\
\text { WAT }\end{array}$ & [275] \\
\hline (4) Neuregulin-4 & YES & YES & YES & Beige & $\begin{array}{l}\text { Brown/ } \\
\text { beige }\end{array}$ & YES & Positive & L, SNS & [276-279] \\
\hline \multicolumn{10}{|c|}{ (c) Factors Released for Regulation of Thermogenesis and Metabolic Homeostasis } \\
\hline $\begin{array}{l}\text { (1) Fibroblast growth } \\
\text { Factor } 21 \text { (FGF21) }\end{array}$ & YES & YES & YES & $\begin{array}{l}\text { Brown/ } \\
\text { beige }\end{array}$ & $\begin{array}{l}\text { Brown/ } \\
\text { beige }\end{array}$ & YES & Positive & $\begin{array}{l}\text { H, P, } \\
\text { SNS, } \\
\text { WAT, } \\
\text { BAT }\end{array}$ & [280-287] \\
\hline $\begin{array}{l}\text { (2) Fibroblast growth Factor } \\
6 \& 9 \text { (FGF6 \& FGF9) }\end{array}$ & $\mathrm{N} / \mathrm{A}$ & YES & $\mathrm{N} / \mathrm{S}$ & $\begin{array}{l}\text { Brown/ } \\
\text { beige }\end{array}$ & $\begin{array}{l}\text { Brown/ } \\
\text { beige }\end{array}$ & Yes & Positive & BAT, WAT & [201] \\
\hline (3) Endothelin-1 (ET-1) & YES & YES & $\mathrm{N} / \mathrm{A}$ & $\mathrm{N} / \mathrm{A}$ & $\begin{array}{l}\text { Brown/ } \\
\text { beige }\end{array}$ & YES & Negative & BAT, WAT & [288] \\
\hline
\end{tabular}


Table 1. Cont.

\begin{tabular}{|c|c|c|c|c|c|c|c|c|c|}
\hline \multirow{2}{*}{ Type of Secretion } & \multicolumn{3}{|c|}{ Physiological Function } & \multicolumn{2}{|c|}{$\begin{array}{l}\text { Secreted by BAT/Beige } \\
\text { In Vivo }\end{array}$} & \multirow{2}{*}{$\begin{array}{l}\text { Secreted by } \\
\text { BAT/Beige } \\
\text { In Vitro }\end{array}$} & \multirow{2}{*}{$\begin{array}{l}\text { Overall } \\
\text { Thermogenic } \\
\text { Effect }\end{array}$} & \multirow{2}{*}{$\begin{array}{l}\text { Target } \\
\text { Organs }\end{array}$} & \multirow{2}{*}{ References } \\
\hline & Autocrine & Paracrine & Endocrine & Humans & Rodents & & & & \\
\hline $\begin{array}{l}\text { (4) Angiopoietin-like } 8 \\
\text { (ANGPTL8) }\end{array}$ & YES & YES & N/A & Brown & Brown & YES & Negative & BAT & [289-291] \\
\hline $\begin{array}{l}\text { (5) Angiopoietin-like } 4 \\
\text { (ANGPTL4) }\end{array}$ & YES & YES & N/A & Brown & Brown & YES & Negative & BAT & [292-294] \\
\hline $\begin{array}{l}\text { (6) Growth and differentiation } \\
\text { Factor-8 (GDF-8/myostatin) }\end{array}$ & YES & YES & YES & N/A & Brown & $\mathrm{N} / \mathrm{A}$ & Negative & BAT, SM & [295-297] \\
\hline (7) Triiodothyronine (T3) & YES & N/A & ? & Brown & Brown & YES & Positive & BAT & [298-301] \\
\hline (8) Adenosine & YES & N/A & N/A & N/A & Brown & YES & Positive & BAT, WAT & [302] \\
\hline $\begin{array}{l}\text { (9) Ependymin-related } \\
\text { protein } 1 \text { (EPDR1) }\end{array}$ & YES & YES & N/A & Brown & Brown & YES & Positive & $\begin{array}{l}\text { BAT, } \\
\text { WAT }\end{array}$ & [303] \\
\hline (10) Follistatin-like 1 (FSTL-1) & YES & YES & N/A & $\mathrm{N} / \mathrm{A}$ & Brown & YES & Positive & BAT & {$[254,304]$} \\
\hline (11) Endocannabinoids & YES & YES & $\mathrm{N} / \mathrm{A}$ & $\mathrm{N} / \mathrm{A}$ & Brown & YES & Negative & BAT & [305-307] \\
\hline $\begin{array}{l}\text { (12) Low-density lipoprotein } \\
\text { receptor relative, soluble } \\
\text { form (sLR 11) }\end{array}$ & YES & $\mathrm{N} / \mathrm{A}$ & N/A & N/A & Brown & YES & Negative & BAT & [308] \\
\hline $\begin{array}{l}\text { (13) SLIT2 and C-terminal } \\
\text { fragment of SLIT2 } \\
\text { protein (SLIT-2C) }\end{array}$ & YES & $\mathrm{N} / \mathrm{A}$ & N/A & $\mathrm{N} / \mathrm{A}$ & $\begin{array}{l}\text { Brown/ } \\
\text { beige }\end{array}$ & N/A & Positive & $\begin{array}{l}\text { BAT, } \\
\text { WAT }\end{array}$ & {$[309,310]$} \\
\hline $\begin{array}{l}\text { (14) Bone morphogenetic } \\
\text { protein-8b (BMP-8b) }\end{array}$ & YES & YES & YES & $\mathrm{N} / \mathrm{A}$ & Brown & YES & Positive & BAT, SNS & {$[277,311,312]$} \\
\hline $\begin{array}{l}\text { (15) Insulin-like growth } \\
\text { factor-binding } \\
\text { protein } 2 \text { (IGFBP-2) }\end{array}$ & YES & N/A & YES & YES & $\begin{array}{l}\text { Brown/ } \\
\text { Beige }\end{array}$ & $\mathrm{N} / \mathrm{A}$ & Negative & B, BAT & [313-317] \\
\hline $\begin{array}{l}\text { (16) 3-methyl-2-oxovaleric } \\
\text { acid }\end{array}$ & YES & YES & YES & Beige & Beige & YES & Positive & $\begin{array}{l}\text { MC, BAT, } \\
\text { WAT }\end{array}$ & [318] \\
\hline (17) 5-oxoproline & YES & YES & YES & Beige & Beige & YES & Positive & $\begin{array}{l}\text { MC, BAT, } \\
\text { WAT }\end{array}$ & [318] \\
\hline (18) $\beta$-hydroxyisobutyric acid & YES & YES & YES & Beige & Beige & YES & Positive & $\begin{array}{l}\text { MC, BAT, } \\
\text { WAT }\end{array}$ & [318] \\
\hline \multicolumn{10}{|c|}{ (d) Factors Released for Regulation of Immune Cells within Brown and/or Beige Adipose Tissue } \\
\hline (1) Interleukin-6 (IL-6) & YES & YES & YES & $\mathrm{N} / \mathrm{A}$ & $\begin{array}{l}\text { Brown/ } \\
\text { beige }\end{array}$ & YES & Positive & $\begin{array}{l}\text { MC, BAT } \\
\text { WAT, P, H }\end{array}$ & {$[286,319-322]$} \\
\hline $\begin{array}{l}\text { (2) C-X-C motif chemokine } \\
\text { ligand-14 (CXCL-14) }\end{array}$ & YES & YES & N/A & N/A & Brown & YES & Positive & BAT, MC & [323] \\
\hline (3) Adiponectin & YES & YES & N/A & $\mathrm{N} / \mathrm{A}$ & Beige & YES & Positive & WAT, MC & [324] \\
\hline (4) Meteorin-like (METRNL) & YES & YES & N/A & N/A & Beige & YES & Positive & WAT, MC & [325] \\
\hline $\begin{array}{l}\text { (5) Growth and differentiation } \\
\text { Factor-15 (GDF-15) }\end{array}$ & YES & YES & $\mathrm{N} / \mathrm{A}$ & $\mathrm{N} / \mathrm{A}$ & $\begin{array}{l}\text { Brown/ } \\
\text { beige }\end{array}$ & YES & Positive & BAT, MC & {$[326,327]$} \\
\hline $\begin{array}{l}\text { (6) Insulin-like growth } \\
\text { Factor (IGF-1) }\end{array}$ & YES & $\mathrm{N} / \mathrm{A}$ & YES & N/A & Brown & YES & Positive & BAT, L, MC & [328-331] \\
\hline (7) Chemerin & YES & YES & N/A & N/A & Brown & YES & Negative & BAT, MC & {$[254,332,333]$} \\
\hline \multicolumn{10}{|c|}{ (e) Exosomal MicroRNAs } \\
\hline (1) miRNA-99b & $\mathrm{N} / \mathrm{A}$ & N/A & YES & $\mathrm{N} / \mathrm{A}$ & Brown & $\mathrm{N} / \mathrm{A}$ & Negative & $\mathrm{L}$ & [334] \\
\hline (2) miRNA-92a & YES & $\mathrm{N} / \mathrm{A}$ & $\mathrm{N} / \mathrm{A}$ & Brown & Brown & YES & Negative & BAT & [335] \\
\hline \multicolumn{10}{|c|}{ (f) Additional Regulatory Factors } \\
\hline $\begin{array}{l}\text { (1) s100b and nerve growth } \\
\text { factor (NGF) }\end{array}$ & YES & YES & N/A & Brown & Brown & YES & Positive & BAT & [336-338] \\
\hline $\begin{array}{l}\text { (2) Wingless-related MMTV } \\
\text { integration site 10b (WNT10b) }\end{array}$ & $\mathrm{N} / \mathrm{A}$ & YES & N/A & N/A & Beige & NA & Negative & $\mathrm{BM}$ & [313] \\
\hline $\begin{array}{l}\text { (3) Retinol binding protein-4 } \\
\text { (RBP-4) }\end{array}$ & $?$ & $?$ & $?$ & N/A & Brown & YES & $?$ & - & {$[254,339-341]$} \\
\hline
\end{tabular}

SM: skeletal muscle, MC: recruitment of macrophages, WAT: white adipose tissue (induction of browning/formation of beige phenotype),

SNS: sympathetic nervous system, L: liver, H: heart, BAT: brown adipose tissue, P: pancreas, B: bone (remodeling), BM: bone marrow.

\section{Brown and Beige Adipose Tissue in Obesity, Aging and Metabolic Disease}

Obesity is the major contributor to the development of metabolic diseases such as IR, T2D, dyslipidemia, and CVD. These metabolic disorders are also observed during 
aging [342] raising the hypothesis that unhealthy excess of body fat may accelerate the aging processes. In this regard, diet-induced obese mice are shorter-lived compared to their controls [343]. Similarly, in obese humans, the risk of premature death is increased by 1.45 to 2.76 folds [344]. The pathophysiology of obesity and aging-associated diseases are complex and share dysregulations at the cellular level [342,345]. Consistent with this, robust evidence suggests that changes in AT distribution and metabolic dysfunction are implicated in the development and disease progression during obesity and aging [346-348]. Here we discuss how obesity changes AT biology and its implication for the development of the metabolic syndrome. Some factors altering the AT and contributing to obesity and aging are summarized in Figure 1.

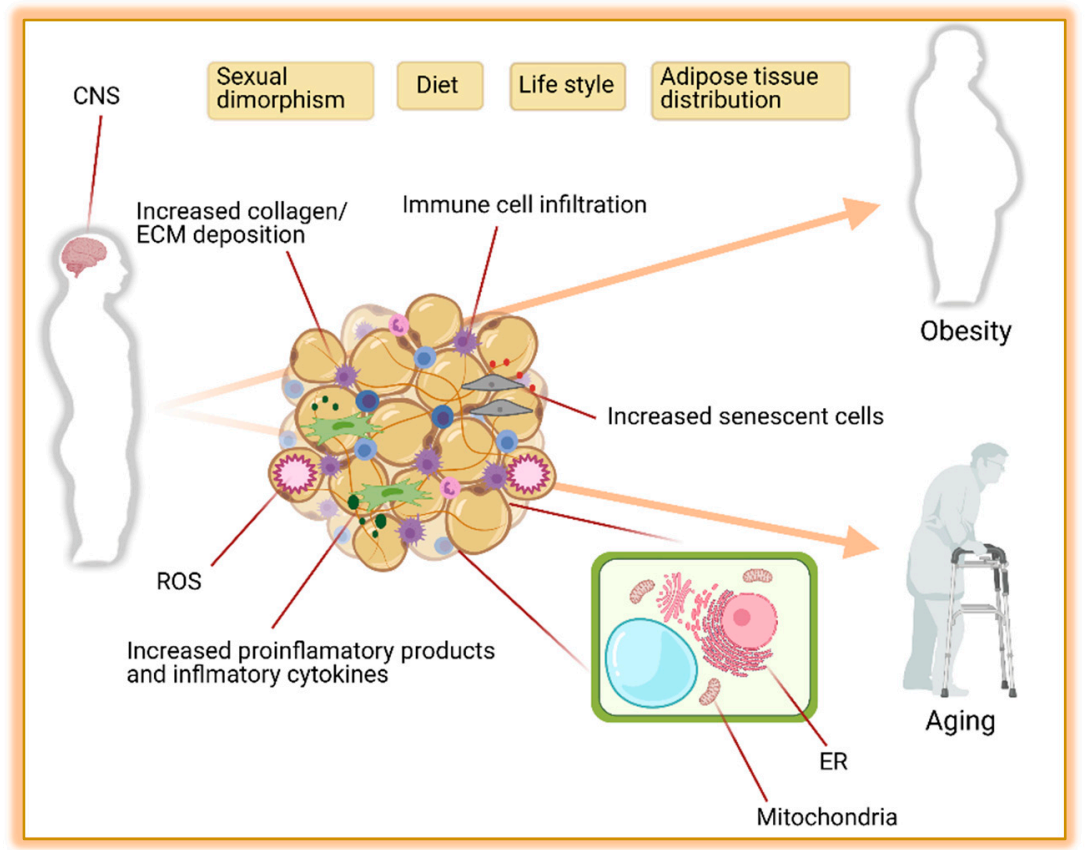

Figure 1. The leading causes of obesity and aging are driven by adipose tissue distribution, function, and environment. Contributions of the central nervous system (CNS), sexual dimorphism, diet, life style, and adipose tissue distribution to obesity and aging are well known. In addition, the composition of adipose tissue itself with increased collagen, extra cellular matrix (ECM), reactive oxygen species (ROS), immune cells, macrophages, and senescent cells is another major contributor to obesity and aging. Furthermore, the functionality of mitochondria and endoplasmic reticulum (ER) in adipocytes plays an important role in preventing obesity and aging complications. Figure created with @BioRender.io.

\subsection{Adipose Tissue Distribution}

In humans, AT distribution can be influenced by sexual hormones, diet, and aging. In general, females exhibit higher scWAT (gynoid fat deposition) and BAT mass, while vWAT is more preeminent in men (android fat deposition) [349]. During obesity, even though AT expansion is observed in all types of fat depots, female subjects very often present lower visceral and larger subcutaneous AT compared with males [350]. This sexual dimorphism is also observed in BAT, where BAT mass [30], and Ucp1 mRNA expression are still higher in women [351]. Genetics and hormones are the major players in sexual dimorphism [352], however, some evidence suggests that these differences persist even after menopause [30]. Interestingly, this dimorphism is associated with a lower risk to develop metabolic diseases in women and may contribute to a longer lifespan compared to men [353]. 


\subsection{Metabolic Function}

It is now appreciated that AT function is also regulated in a sex-dependent manner that is widely reviewed elsewhere [349,354,355]. Here we will give an overall view of some biological processes that are impaired in the AT of obese mice and humans. These processes are interconnected and mediate the development of obesity-associated diseases.

\subsubsection{Sympathetic Nervous System (SNS)}

Overactivation of the sympathetic nervous system is often observed in obese subjects which contributes to the development of high blood pressure and cardiovascular diseases [356-360]. In AT, hyperactivation of the SNS pathway induces negative feedback, and downregulates the abundance of adrenergic receptors, decreasing the lipolytic [357], and thermogenic capacity [361]. This contributes to an increased WAT expansion, whitening of beige adipocytes [362], and decreased basal EE. Additionally, whitening of beige fat induces macrophage infiltration, brown adipocyte death and increased senescent cells, crown-like structure (CLS) formation, fibrosis, and local inflammation [362].

\subsubsection{Endoplasmic Reticulum Stress (ER)}

This organelle is composed of a membranous network responsible for the synthesis, maturation, and trafficking of proteins. It is also highly sensitive to nutrient availability. Upon nutrient overload, the increased protein synthesis followed by their misfolding and accumulation in the ER lumen induces ER stress. As a result, proteins from the unfolded protein response (UPR) Atf6, Perk, and Ire1 are recruited to reestablish the ER homeostasis [363]. In obesity, this process is hyperactivated in multiples tissues including adipose. This contributes to AT inflammation and insulin resistance [364,365]. Mechanistically, Atf6 and Perk acts through activation of NF-kB which translocate to the nucleus and induces the expression of pro-inflammatory cytokines such as IL- 1 and TNF $\alpha$, while Ire1a interacts with the tumor necrosis factor-a (TNF $\alpha$ )-receptor-associated factor 2 (Traf2), activates Jnk and IkB kinase (IKK) and downstream mediators of inflammation [363,366]. Adipocyte ER stress also leads to increased basal lipolysis through downregulation of perilipin and insulin receptor, decrease adiponectin assembling and secretion, as well as decrease in leptin release [366,367].

\subsubsection{Mitochondrial Dysfunction}

As the central contributors to energy metabolism, mitochondria play key roles in the production of ATP, oxidative phosphorylation, production of reactive oxygen species (ROS), and $\mathrm{Ca}^{2+}$ homeostasis. Mitochondria also play an important role in AT homeostasis and remodeling $[368,369]$. The rate-limiting steps of oxidative reaction that regulate the thermogenesis in the beige adipocytes take place in mitochondria. Brown and beige fat depots are packed with mitochondria (the cells' tiny power plants) with high expression of Ucp1 across the mitochondria inner membrane which uncouples the respiratory chain from ATP (energy) and thereby, it increases thermogenesis by heat production. The browning of the WAT is accompanied by an increase in the number of mitochondria caused by de novo biogenesis of mitochondria as well as mitochondrial fission (fission separates one into two) [370]. Contrarily, a reduced number of mitochondria resulted from mitochondrial fusion (fusion joins two mitochondria together), and mitochondrial disappearance (mitophagy) is reported during beige to white fat transition [371,372]. Mitochondrial dysfunction is present in many organs including WAT and BAT. It is characterized by increased mitochondrial DNA (mtDNA) mutations and damage, decreased oxidative phosphorylation (OXPHOS), reduced activity of metabolic enzymes, as well as changes in mitochondrial morphology, dynamics, and biogenesis [373-375]. In line with this, multiple symmetric lipomatosis (MSL), an adipose disorder (AD) characterized by upper body lipomatous masses, is frequently linked to multiple mutations in mitochondrial genes such as Mttk (gene encoding mitochondrial tRNA lysine involved in the assembly of proteins that carry 
out oxidative phosphorylation), and Mfn2 (gene encoding mitofusin 2 that helps to regulate the morphology of mitochondria by controlling the fusion process) $[376,377]$.

\subsubsection{Inflammation and Endocrine Dysfunction}

During obesity, adipocytes increase in size and number to accommodate the excess of nutrients in form of lipids. Excessive expansion of WAT followed by capillary rarefaction triggers a cascade of the biological processes including, ER-stress, mitochondrial dysfunction, hypoxia, changes in extracellular matrix mobility, and adipocyte death which are thought to contribute to inflammation [378]. Activation of the inflammatory response leads to the secretion of several pro-inflammatory factors TNF $\alpha, \mathrm{Il}-1 \mathrm{~b}, \mathrm{Il}-6$, and monocyte chemoattractant protein (Mcp-1) from adipocytes $[379,380]$. This is accompanied by infiltration of immune cells such as M1 macrophages [381], Cd8+ T cells [382], B cells [383], and eosinophils [384], thereby enhancing local and systemic inflammation [385]. The chronic low-grade inflammatory state observed in obesity is an important contributor to AT insulin resistance (IR). This is important because impaired insulin signaling in adipocytes leads to uncontrolled basal lipolysis, which can induce cell death, and also increase the circulating levels of FFAs. In turn, this leads to lipids accumulation in non-adipose organs inducing systemic IR and increasing the risk to develop cardiovascular disease and T2D [386-388].

\section{Activation of Thermogenesis as Therapy for Obesity-Associated Metabolic Diseases}

Over the years, the development of drugs to treat obesity was mainly focused on weight loss, primarily due to a reduction in food intake. Many of these molecules failed to meet the desired efficacy and some of them were even withdrawn from the market because of their limited success and harmful side effects [389,390]. This, with the observation that adult humans have BAT with the capability to dissipate energy, activation of BAT and thermogenesis began to be envisioned as therapy. Ever since the development of interventions that can stimulate browning of WAT as well as BAT mass increase and activation have gained greater attention and will be discussed here. A summary of the potential therapeutic interventions for obesity and metabolic disorders accompanied by aging is shown in Figure 2.

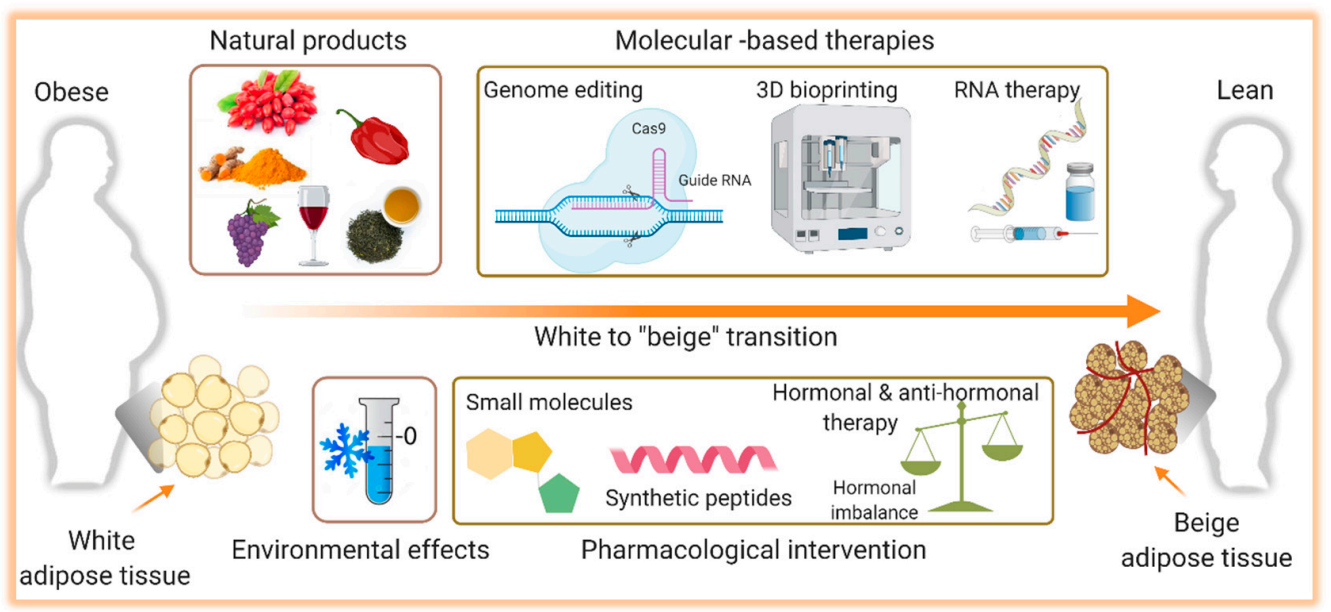

Figure 2. Illustration of the potential therapeutic interventions for the therapy of obesity. Induction of the browning process, the transition from white to brown-like or beige adipocytes, holds a promising therapeutic potential to combat obesity and its complications. Several pharmacological (small molecules, synthetic peptides, hormonal analogs) and non-pharmacological (natural products) interventions are known to induce browning. The role of environmental challenges such as cold exposure on white adipose tissue browning and thermogenesis is also identified. In addition, molecular-based therapies including CRIPR-based genome editing, RNA therapy, and 3D bioprinting are evolving approaches to alter the white adipocytes as a therapeutic target in obesity. Figure created with @BioRender.io. 


\subsection{Cold-Induced Thermogenesis}

Currently, cold exposure is the most effective intervention to activate BAT in obese humans improving whole-body insulin sensitivity and weight loss [391,392]. Some candidates have been strongly suggested to mediate the metabolic effect of BAT activation. One of the most well-investigated molecules is FGF21. This protein is mainly present in the liver, but it is also expressed in, skeletal muscle, pancreas, WAT, and BAT. Upon short-term cold exposure, FGF21 expression in adipocytes is significantly increased [393,394]. FGF21 induces browning of WAT in an autocrine manner [395] and enhances insulin signaling in the same cell [396]. Moreover, cold exposure also increases the circulating levels of FGF21 [397,398] which activates the SNS enhancing EE and weight loss [398].

Most recently, another member from the FGF family, FGF9, was also demonstrated to be upregulated in the scWAT and BAT of cold-exposed mice. Exerting an autocrineparacrine regulation, FGF9 binds to FGFR3 receptor in adipocytes to regulate Ucp1 expression [399]. In addition to proteins, cold exposure induces the secretion of lipid species from BAT including 12,13-diHOME and 12-HEPE, which enhance BAT fatty acids [6] and glucose uptake [400] respectively. Altogether, cold exposure triggers an intricate metabolic network between the central nervous system (CNS) and AT which redirects the utilization of circulating glucose and FFAs to support heat production ultimately improving WAT and BAT function and whole-body metabolism.

\subsection{Natural Thermogenic Compounds}

\subsubsection{Berberine}

Berberine is a plant-based alkaloid compound traditionally used in Chinese medicine to treat diarrhea and some infectious diseases [401]. Berberine has been extensively studied due to its potential as a cardioprotective, anti-hyperlipidemic, and antidiabetic compound [402,403]. Most recently, berberine was shown to induce Ucp1 gene expression in brown and white adipocytes through activation of $5^{\prime}$ AMP-activated protein kinase (AMPK) leading to an increased BAT activity, improved EE, and decreased weight gain in $\mathrm{db} / \mathrm{db}$ mice [404]. More importantly, 1 month of berberine supplementation increased BAT volume and activity, reduced body weight, improved insulin sensitivity in patients with non-alcoholic fatty liver [405].

\subsubsection{Capsaicin and Capsinoids}

Capsaicin and its analog capsinoids are compounds found in red peppers [406]. Several studies have shown the anti-obesity, anti-diabetic, and anti-inflammatory effects of these compounds. In rodents, capsinoids supplementation improves glucose metabolism, hepatic lipid content and enhances cold-induced EE and WAT browning [407]. In humans, chronic supplementation with capsinoids over six weeks decreased body weight and enhanced cold-induced thermogenesis in healthy adult men lacking detectable BAT, suggesting that cold exposure in combination with capsinoid ingestion recruits the activation of brown and beige adipocytes [392]. These adaptations occur through activation of the transient receptor potential cation channel subfamily V member 1 TRPV1 receptor (transient receptor potential cation channel subfamily $\mathrm{V}$ member 1 ) in the gut which sends signals to the CNS leading to $\beta 2-\mathrm{AR}$ signaling activation in AT [407].

\subsubsection{Curcumin}

Curcumin is a well-known flavonoid found in turmeric root. It has many therapeutic properties including, antioxidant, anti-inflammatory, anti-diabetic, and anti-obesity [408]. This is corroborated by the observation that curcumin supplementation reduces BMI, percentage of body fat, lower circulating leptin, and increased adiponectin levels in obese humans [409]. Part of these effects may be explained by the induction of browning in WAT via AMPK activation $[410,411]$ and inhibition of preadipocyte differentiation by downregulating the Ppary and C/ebp $\alpha$ [412]. In mice, supplementation with curcumin for 50 days induces higher expression of mitochondrial and thermogenic genes, higher NE 
levels, increased $\beta 3$-AR expression in scWAT, improved cold tolerance, and lower body fat [411].

\subsubsection{Green Tea}

Green tea is made from the leaves of Camellia sinensis and contains several different catechins, especially epigallocatechin gallate (EGCG), which accounts for about $50 \%$ to $70 \%$ of green tea catechins, and caffeine [413]. Green tea extract has several metabolic properties such as antioxidant, anti-hypertensive, anti-carcinogenic, hypocholesterolemia, and has also been shown to induce weight loss [414,415]. This evidence is supported by the reduction of body weight, mainly due to loss of vWAT mass, in obese women and men subjects submitted to catechins supplementation [414,416]. There are several potential mechanisms proposed to explain the anti-obesity effects of green tea compounds such as inhibition of de novo lipogenesis, increased FA oxidation, browning of WAT, and activation of BAT [415,417]. The effect of thermogenesis seems to be dependent on the interaction between catechins, caffeine, and NE. At the cellular level, catechins inhibit catechol-Omethyltransferase, one of several enzymes that degrade catecholamines, and caffeine inhibits phosphodiesterase resulting in higher levels of cyclic AMP (cAMP). This results in higher levels of NE and cAMP leading to fat oxidation and thermogenic activation [418].

\subsubsection{Resveratrol}

3,5, $4^{\prime}$-trihydroxy-trans-stilbene (Resveratrol) is a natural compound that belongs to polyphenols' group. It is found in more than 70 different plants including grapes and has gained greater attention over the years due to its biological properties including the weight loss effect [419]. Consistent with this, resveratrol supplementation was shown to reduce the weight gain in diet-induced obese mice. This effect was mediated by improved oxidative capacity in muscle and AT and increased EE [420]. Moreover, resveratrol inhibits adipocyte differentiation and lipid accumulation [421] and induces browning of WAT [422]. The molecular effect of resveratrol is not completely understood, but some evidence suggests that interaction between AMPK activation and NAD-dependent protein deacetylase sirtuin-1 (Sirt1) leads to increased expression of Pgc1 $\alpha$, thereby inducing mitochondrial biogenesis [422]. In humans, the effect on weight loss and thermogenesis is not clear and differences in dose and duration of resveratrol supplementation across studies have yielded inconsistent results. Despite this limitation, some beneficial effects including improved HOMA-index have been observed 30 days after resveratrol supplementation, suggesting positive effects on insulin sensitivity [423].

\subsection{Pharmacological Intervention}

\subsubsection{Beta 3-Agonist Drugs}

In mice, pharmacological activation of BAT using $\beta 3$-adrenoreceptor agonist drugs increases EE, reduces circulating insulin levels and body fat [424-426]. However, the translational potential of this approach is debatable since human $\beta 3$-adrenoceptor have different binding characteristics compared to rodents and drug bioavailability also varies across species, which limits the capacity to effectively activate BAT $[427,428]$. Despite these limitations, a new FDA-approved drug, referred to as Mirabegron, developed to treat overreactive bladder, has been shown to improve glucose tolerance and FA oxidation. At its maximal concentration ( $200 \mathrm{mg}$ ), a single dose of Mirabegron increased BAT glucose uptake and WAT lipolysis [429]. Moreover, chronic Mirabegron treatment enhances BAT activity, induces WAT loss, increases HDL, and improves insulin sensitivity in lean and obese subjects $[13,430]$. Nevertheless, a recent study performed by Blondin et al. raises some concerns regarding the use of Mirabegron [431]. According to the authors, in human adipose tissue, Mirabegron seems to work mainly through b2-adrenoceptor, since b3-adrenoceptor is quite low expressed. This suggesting that this drug lacks receptor selectivity [431] and may explain some of its effects on heart rate and blood pressure [429]. 


\subsubsection{GLP-1 Receptor Agonist}

Glucagon-like peptide 1 is a molecule secreted in response to the absorption of nutrition by the L-cells in the gastrointestinal tract. Innumerous clinical studies have demonstrated its capacity to reduce food intake, enhance insulin secretion, inhibit gluconeogenesis and improve skeletal muscle IR. Besides, recent evidence suggests that GLP-1 increased browning of WAT and BAT activation via GLP-1 binding to its receptor GLP-1R in the hypothalamus [432-434]. Since GLP-1 has a short half-life, GLP-1 analogs have been developed and approved as therapies to treat obesity and T2D [432]. In mice, GLP-1 analogs have the potential to induce WAT browning and BAT activation [435]. In obese and T2D humans, GLP-1 analogs enhance body weight loss and improve overall metabolism, whether this is dependent on decreased food intake or increased BAT activation yet needs to be addressed.

\subsection{Gene Therapy}

\subsubsection{Ex Vivo Gene Therapy}

The revolutionary approach of cellular-based therapy combined with gene editing has been considered an alternative to treat metabolic diseases and a pre-clinical study performed has shown promising results. Wang et al. used the CRISPR-Cas9 system (CRISPR-SAM) to overexpress Ucp1 in human white preadipocytes to generate the human beige/brown-like adipocytes (HUMBLE). These cells exhibit gene signatures and metabolic function similar to human brown adipocytes. Upon transplantation into mice, the HUMBLE cells differentiate into mature and functional adipocytes. Importantly, transplantation of HUMBLE cells into diet-induced obese mice resulted in increased heat production, decreased weight gain, improved insulin sensitivity, and glucose tolerance. Most strikingly, these metabolic effects were induced by the communication between the HUMBLE cells and the endogenous BAT via nitric oxide [14]. Looking forward one could envision the generation of personalized HUMBLE cells, where adipocyte progenitor cells would be isolated from the patient's scWAT, cultivated in vitro, transformed into HUMBLE, and placed back into the patient.

\subsubsection{In Vivo Gene Therapy}

A more straightforward alternative to modulating the expression of a gene or a protein is the delivery of nucleotides (DNA or RNA species) to the cell of interest. Over the years, a variety of viral and non-viral methods have been developed to deliver DNA, RNA, or protein to human cells to treat different types of diseases. Currently, 12 gene therapy-based drugs are available in the market and many others are being tested in clinal trials [436], however, none of them were developed with the intent to treat obesity and its associated disease.

Hopefully, in the near future, with the use of viral vectors, we will be able to target specific tissues and overexpress a protein of interest. In line with this, one could envision the transfection of white and brown AT with the Ucp1 mRNA. A second approach will be to use the same CRISPR-Cas9 system used to generate the HUMBLE cells [14] to induce endogenous Ucp1 overexpression. The advantage of this technique compared to the others discussed earlier relies on the fact that it can be personalized, it may induce more persistent therapeutic outcomes reducing or eliminating the need for medication and avoiding any complication related to the cell transplantation.

\section{5. $3 D$ Bioprinting}

3D bioprinting technology, allowing the construction of biological tissue in an accurate and reproducible manner is a potential approach for tissue engineering and regenerative medicine. AT bioprinting has particular needs, including morphology, composition, and heterogeneity, as well as the microenvironment, and crosstalk with other cells such as immune cells, vascularization, and ECM. 3D bioprinting of brown and beige AT aiming to create an optimal size and function and transplanting it to the patients seems like a potential strategy in the treatment of obesity and metabolic diseases. This could also be used for 
testing chemical and pharmaceutical products as well as evaluating the toxicity of the new drugs. Kuss et al. used 3D printed gels to test the effects of stiff vs. soft gels on immortalized human white and brown AT precursor cells and showed that white progenitors prefer soft gels to differentiate as compared to brown progenitors that their differentiation reaches an optimal level interacting with stiffer gels [437]. The feasibility of bioprinting the breast structure including the AT and mammary glands has been discussed by Chen et al., and despite several challenges including poor vascularization, it is a promising strategy to count on for the treatment of patients with breast cancer [438]. Nonetheless, most of the bioprinted tissue and organs are yet at the level of laboratory uses and there is a long way till they will be clinically applicable.

\section{Perspectives}

More than just a number on a scale or the body size, obesity is linked to many diseases and complications, including diabetes, heart disease, and many types of cancer. It is a complex dilemma and a public health concern worldwide. Activating BAT and induction of WAT browning and thereby increasing the thermogenesis is a promising strategy to improve the whole-body energy metabolism and combat obesity and its complications. In line with this, the majority of studies are performed in animals or in vitro in $2 \mathrm{D}$ cell cultures. Hence, the detailed mechanisms underlying the browning of WAT and BAT activation needs to be further investigated in humans. Furthermore, considering the great heterogeneity of AT, in vitro studies shall highly consider the use of 3D culture models of AT in which the native tissue function and its cellular heterogeneity would be resumed. Finally, considering the brown and beige AT as therapeutic targets, one must consider the variations that might be caused by the differences in gender, ethnicity, age, and body composition.

Author Contributions: Conceptualization, A.R. and B.B.B.; writing, review and editing, A.R., B.B.B. and A.P.; visualization, A.R.; supervision, A.R.; funding acquisition, A.R. All authors have read and agreed to the published version of the manuscript.

Funding: Dr. Rabiee was partly funded by Nutting Family Foundation.

Institutional Review Board Statement: Not applicable.

Informed Consent Statement: Not applicable.

Data Availability Statement: Not applicable.

Acknowledgments: The authors would like to thank Sean Kodani at Joslin Diabetes Center, Harvard Medical School, for proofreading this manuscript.

Conflicts of Interest: The authors declare no conflict of interest.

\section{References}

1. Reaven, G. Insulin resistance, hypertension, and coronary heart disease. J. Clin. Hypertens. 2003, 5, 269-274. [CrossRef] [PubMed]

2. Hruby, A.; Hu, F.B. The Epidemiology of Obesity: A Big Picture. Pharmacoeconomics 2015, 33, 673-689. [CrossRef] [PubMed]

3. Seale, P.; Lazar, M.A. Brown fat in humans: Turning up the heat on obesity. Diabetes 2009, 58, 1482-1484. [CrossRef]

4. Ikeda, K.; Maretich, P.; Kajimura, S. The Common and Distinct Features of Brown and Beige Adipocytes. Trends Endocrinol. Metab. 2018, 29, 191-200. [CrossRef]

5. Yore, M.M.; Syed, I.; Moraes-Vieira, P.M.; Zhang, T.; Herman, M.A.; Homan, E.A.; Patel, R.T.; Lee, J.; Chen, S.; Peroni, O.D.; et al. Discovery of a class of endogenous mammalian lipids with anti-diabetic and anti-inflammatory effects. Cell 2014. [CrossRef] [PubMed]

6. Yu, Y.H.; Ginsberg, N.H. Adipocyte signaling and lipid homeostasis: Sequelae of insulin-resistant adipose tissue. Circ. Res. 2005, 96, 1042-1052. [CrossRef]

7. Scherer, P.E.; Williams, S.; Fogliano, M.; Baldini, G.; Lodish, H.F. A novel serum protein similar to C1q, produced exclusively in adipocytes. J. Biol. Chem. 1995, 270, 26746-26749. [CrossRef]

8. Zhang, Y.; Proenca, R.; Maffei, M.; Barone, M.; Leopold, L.; Friedman, J.M. Positional cloning of the mouse obese gene and its human homologue. Nature 1994, 372, 425-432. [CrossRef] [PubMed]

9. Lihn, A.S.; Pedersen, S.B.; Richelsen, B. Adiponectin: Action, regulation and association to insulin sensitivity. Obes. Rev. 2005, 6, 13-21. [CrossRef] 
10. Goody, D.; Pfeifer, A. MicroRNAs in brown and beige fat. Biochim. Biophys. Acta Mol. Cell. Biol. Lipids 2019, 1864, 29-36. [CrossRef]

11. Luo, L.; Liu, M. Adipose tissue in control of metabolism. J. Endocrinol. 2016, 231, R77-R99. [CrossRef]

12. Lessing, M.P.A.; Hyman, N.M. Intracranial haemorrhage caused by amphetamine abuse. J. R. Soc. Med. 1989, 82, 766-767. [CrossRef] [PubMed]

13. O'Mara, A.E.; Johnson, J.W.; Linderman, J.D.; Brychta, R.J.; McGehee, S.; Fletcher, L.A.; Fink, Y.A.; Kapuria, D.; Cassimatis, T.M.; Kelsey, N.; et al. Chronic mirabegron treatment increases human brown fat, HDL cholesterol, and insulin sensitivity. J. Clin. Investig. 2020, 130. [CrossRef]

14. Wang, C.H.; Lundh, M.; Fu, A.; Kriszt, R.; Huang, T.L.; Lynes, M.D.; Leiria, L.O.; Shamsi, F.; Darcy, J.; Greenwood, B.P.; et al. CRISPR-engineered human brown-like adipocytes prevent diet-induced obesity and ameliorate metabolic syndrome in mice. Sci. Transl. Med. 2020, 12. [CrossRef]

15. Cinti, S. The adipose organ. In Prostaglandins Leukotrienes and Essential Fatty Acids; Springer: Berlin/Heidelberg, Germany, 2005; Volume 73, pp. 9-15. [CrossRef]

16. Rosen, E.D.; Spiegelman, B.M. What we talk about when we talk about fat. Cell 2014, 156, 20-44. [CrossRef] [PubMed]

17. Peirce, V.; Carobbio, S.; Vidal-Puig, A. The different shades of fat. Nature 2014, 510, 76-83. [CrossRef]

18. Wu, J.; Boström, P.; Sparks, L.M.; Ye, L.; Choi, J.H.; Giang, A.H.; Khandekar, M.; Virtanen, K.A.; Nuutila, P.; Schaart, G.; et al. Beige adipocytes are a distinct type of thermogenic fat cell in mouse and human. Cell 2012, 150, 366-376. [CrossRef]

19. Cousin, B.; Cinti, S.; Morroni, M.; Raimbault, S.; Ricquier, D.; Penicaud, L.; Casteilla, L. Occurrence of brown adipocytes in rat white adipose tissue: Molecular and morphological characterization. J. Cell Sci. 1992, 103, 931-942. [CrossRef]

20. Guerra, C.; Koza, R.A.; Yamashita, H.; Walsh, K.; Kozak, L.P. Emergence of brown adipocytes in white fat in mice is under genetic control effects on body weight and adiposity. J. Clin. Investig. 1998, 102, 412-420. [CrossRef]

21. Himms-Hagen, J.; Melnyk, A.; Zingaretti, M.C.; Ceresi, E.; Barbatelli, G.; Cinti, S. Multilocular fat cells in WAT of CL-316243treated rats derive directly from white adipocytes. Am. J. Physiol. Cell Physiol. 2000, 279, C670-C681. [CrossRef]

22. Chevalier, C.; Stojanović, O.; Colin, D.J.; Suarez-Zamorano, N.; Tarallo, V.; Veyrat-Durebex, C.; Rigo, D.; Fabbiano, S.; Stevanović, A.; Hagemann, S.; et al. Gut Microbiota Orchestrates Energy Homeostasis during Cold. Cell 2015, 163, $1360-1374$. [CrossRef] [PubMed]

23. Suárez-Zamorano, N.; Fabbiano, S.; Chevalier, C.; Stojanović, O.; Colin, D.J.; Stevanović, A.; Veyrat-Durebex, C.; Tarallo, V.; Rigo, D.; Germain, S.; et al. Microbiota depletion promotes browning of white adipose tissue and reduces obesity. Nat. Med. 2015, 21, 1497-1501. [CrossRef]

24. Fabbiano, S.; Suárez-Zamorano, N.; Rigo, D.; Veyrat-Durebex, C.; Stevanovic Dokic, A.; Colin, D.J.; Trajkovski, M. Caloric Restriction Leads to Browning of White Adipose Tissue through Type 2 Immune Signaling. Cell Metab. 2016, 24, 434-446. [CrossRef]

25. Tran, T.T.; Kahn, C.R. Transplantation of adipose tissue and stem cells: Role in metabolism and disease. Nat. Rev. Endocrinol. 2010, 6, 195-213. [CrossRef]

26. De Jong, J.M.A.; Larsson, O.; Cannon, B.; Nedergaard, J. A stringent validation of mouse adipose tissue identity markers. Am. J. Physiol. Endocrinol. Metab. 2015, 308, E1085-E1105. [CrossRef]

27. Enerbäck, S. Brown adipose tissue in humans. Int. J. Obes. 2010, 34, S43-S46. [CrossRef]

28. Virtanen, K.A.; Lidell, M.E.; Orava, J.; Heglind, M.; Westergren, R.; Niemi, T.; Taittonen, M.; Laine, J.; Savisto, N.-J.; Enerbäck, S.; et al. Functional Brown Adipose Tissue in Healthy Adults. N. Engl. J. Med. 2009, 360, 1518-1525. [CrossRef]

29. Van Marken Lichtenbelt, W.D.; Vanhommerig, J.W.; Smulders, N.M.; Drossaerts, J.M.A.F.L.; Kemerink, G.J.; Bouvy, N.D.; Schrauwen, P.; Teule, G.J.J. Cold-Activated Brown Adipose Tissue in Healthy Men. N. Engl. J. Med. 2009, 360, 1500-1508. [CrossRef]

30. Cypess, A.M.; Lehman, S.; Williams, G.; Tal, I.; Rodman, D.; Goldfine, A.B.; Kuo, F.C.; Palmer, E.L.; Tseng, Y.-H.; Doria, A.; et al. Identification and Importance of Brown Adipose Tissue in Adult Humans. N. Engl. J. Med. 2009, 360, 1509-1517. [CrossRef]

31. Richard, M.A.; Pallubinsky, H.; Blondin, D.P. Functional characterization of human brown adipose tissue metabolism. Biochem. J. 2020, 477, 1261-1286. [CrossRef]

32. Houštěk, J.; Kopecký, J.; Rychter, Z.; Soukup, T. Uncoupling protein in embryonic brown adipose tissue-Existence of nonthermogenic and thermogenic mitochondria. BBA Bioenerg. 1988, 935, 19-25. [CrossRef]

33. Wang, W.; Kissig, M.; Rajakumari, S.; Huang, L.; Lim, H.W.; Won, K.J.; Seale, P. Ebf2 is a selective marker of brown and beige adipogenic precursor cells. Proc. Natl. Acad. Sci. USA 2014, 111, 14466-14471. [CrossRef]

34. Giralt, M.; Martin, I.; Iglesias, R.; Viñas, O.; Villarroya, F.; Mampel, T. Ontogeny and perinatal modulation of gene expression in rat brown adipose tissue: Unaltered iodothyronine $5^{\prime}$-deiodinase activity is necessary for the response to environmental temperature at birth. Eur. J. Biochem. 1990, 193, 297-302. [CrossRef]

35. Birsoy, K.; Berry, R.; Wang, T.; Ceyhan, O.; Tavazoie, S.; Friedman, J.M.; Rodeheffer, M.S. Analysis of gene networks in white adipose tissue development reveals a role for ETS2 in adipogenesis. J. Cell Sci. 2011, 124, e1. [CrossRef]

36. Poissonnet, C.M.; Burdi, A.R.; Garn, S.M. The chronology of adipose tissue appearance and distribution in the human fetus. Early Hum. Dev. 1984, 10, 1-11. [CrossRef]

37. Berry, R.; Rodeheffer, M.S. Characterization of the adipocyte cellular lineage in vivo. Nat. Cell Biol. 2013, 15, 302-308. [CrossRef]

38. Han, J.; Lee, J.E.; Jin, J.; Lim, J.S.; Oh, N.; Kim, K.; Chang, S.I.; Shibuya, M.; Kim, H.; Koh, G.Y. The spatiotemporal development of adipose tissue. Development 2011, 138, 5027-5037. [CrossRef] 
39. Wang, Q.A.; Tao, C.; Gupta, R.K.; Scherer, P.E. Tracking adipogenesis during white adipose tissue development, expansion and regeneration. Nat. Med. 2013, 19, 1338-1344. [CrossRef]

40. Asahina, K.; Zhou, B.; Pu, W.T.; Tsukamoto, H. Septum transversum-derived mesothelium gives rise to hepatic stellate cells and perivascular mesenchymal cells in developing mouse liver. Hepatology 2011, 53, 983-995. [CrossRef] [PubMed]

41. Cano, E.; Carmona, R.; Muñoz-Chápuli, R. Wt1-expressing progenitors contribute to multiple tissues in the developing lung. Am. J. Physiol. Lung Cell. Mol. Physiol. 2013, 305, L322. [CrossRef] [PubMed]

42. Chau, Y.Y.; Bandiera, R.; Serrels, A.; Martínez-Estrada, O.M.; Qing, W.; Lee, M.; Slight, J.; Thornburn, A.; Berry, R.; Mchaffie, S.; et al. Visceral and subcutaneous fat have different origins and evidence supports a mesothelial source. Nat. Cell Biol. 2014, 16, 367-375. [CrossRef] [PubMed]

43. Rinkevich, Y.; Mori, T.; Sahoo, D.; Xu, P.X.; Bermingham, J.R.; Weissman, I.L. Identification and prospective isolation of a mesothelial precursor lineage giving rise to smooth muscle cells and fibroblasts for mammalian internal organs, and their vasculature. Nat. Cell Biol. 2012, 14, 1251-1260. [CrossRef]

44. Atit, R.; Sgaier, S.K.; Mohamed, O.A.; Taketo, M.M.; Dufort, D.; Joyner, A.L.; Niswander, L.; Conlon, R.A. B-Catenin Activation Is Necessary and Sufficient To Specify the Dorsal Dermal Fate in the Mouse. Dev. Biol. 2006, 296, 164-176. [CrossRef]

45. Billon, N.; Iannarelli, P.; Monteiro, M.C.; Glaviuex-Pardanaud, C.; Richardson, W.D.; Kessaris, N.; Dani, C.; Dupin, E. The generation of adipocytes by the neural crest. Development 2007, 134, 2283-2292. [CrossRef] [PubMed]

46. Lemos, D.R.; Paylor, B.; Chang, C.; Sampaio, A.; Underhill, T.M.; Rossi, F.M.V. Functionally convergent white adipogenic progenitors of different lineages participate in a diffused system supporting tissue regeneration. Stem Cells 2012, 30, 1152-1162. [CrossRef] [PubMed]

47. Sanchez-Gurmaches, J.; Guertin, D.A. Adipocytes arise from multiple lineages that are heterogeneously and dynamically distributed. Nat. Commun. 2014, 5, 1-13. [CrossRef]

48. Le Lievre, C.S.; Le Douarin, N.M. Mesenchymal derivatives of the neural crest: Analysis of chimaeric quail and chick embryos. J. Embryol. Exp. Morphol. 1975, 34, 125-154.

49. Krueger, K.C.; Costa, M.J.; Du, H.; Feldman, B.J. Characterization of cre recombinase activity for in vivo targeting of adipocyte precursor cells. Stem Cell Rep. 2014, 3, 1147-1158. [CrossRef]

50. Lee, K.Y.; Luong, Q.; Sharma, R.; Dreyfuss, J.M.; Ussar, S.; Kahn, C.R. Developmental and functional heterogeneity of white adipocytes within a single fat depot. EMBO J. 2019, 38, e99291. [CrossRef]

51. Sanchez-Gurmaches, J.; Hsiao, W.Y.; Guertin, D.A. Highly selective in vivo labeling of subcutaneous white adipocyte precursors with Prx1-Cre. Stem Cell Rep. 2015, 4, 541-550. [CrossRef]

52. Bergwerff, M.; Gittenberger-de Groot, A.C.; Wisse, L.J.; DeRuiter, M.C.; Wessels, A.; Martin, J.F.; Olson, E.N.; Kern, M.J. Loss of function of the Prx1 and Prx2 hameobox genes alters architecture of the great elastic arteries and ductus arteriosus. Virchows Arch. 2000, 436, 12-19. [CrossRef]

53. Kuratani, S.; Martin, J.F.; Wawersik, S.; Lilly, B.; Eichele, G.; Olson, E.N. The expression pattern of the chick homeobox gene gMHox suggests a role in patterning of the limbs and face and in compartmentalization of somites. Dev. Biol. 1994, 161, 357-369. [CrossRef] [PubMed]

54. Leussink, B.; Brouwer, A.; El Khattabi, M.; Poelmann, R.E.; Gittenberger-de Groot, A.C.; Meijlink, F. Expression patterns of the paired-related homeobox genes MHox Prx1 and S8 Prx2 suggest roles in development of the heart and the forebrain. Mech. Dev. 1995, 52, 51-64. [CrossRef]

55. Shimozaki, K.; Clemenson, G.D., Jr.; Gage, F.H. Erratum to Paired Related Homeobox Protein 1 is a Regulator of Stemness in Adult Neural Stem/Progenitor Cells. J. Neurosci. 2013, 56, 4066-4075.

56. Seale, P.; Bjork, B.; Yang, W.; Kajimura, S.; Chin, S.; Kuang, S.; Scimè, A.; Devarakonda, S.; Conroe, H.M.; Erdjument-Bromage, H.; et al. PRDM16 controls a brown fat/skeletal muscle switch. Nature 2008, 454, 961-967. [CrossRef] [PubMed]

57. Sanchez-Gurmaches, J.; Hung, C.M.; Sparks, C.A.; Tang, Y.; Li, H.; Guertin, D.A. PTEN loss in the Myf5 lineage redistributes body fat and reveals subsets of white adipocytes that arise from Myf5 precursors. Cell Metab. 2012, 16, 348-362. [CrossRef] [PubMed]

58. Shan, T.; Liang, X.; Bi, P.; Zhang, P.; Liu, W.; Kuang, S. Distinct populations of adipogenic and myogenic Myf5-lineage progenitors in white adipose tissues. J. Lipid Res. 2013, 54, 2214-2224. [CrossRef]

59. Sebo, Z.L.; Jeffery, E.; Holtrup, B.; Rodeheffer, M.S. A mesodermal fate map for adipose tissue. Development 2018, 145. [CrossRef] [PubMed]

60. Steinbring, J.; Graja, A.; Jank, A.M.; Schulz, T.J. Flow cytometric isolation and differentiation of adipogenic progenitor cells into brown and brite/beige adipocytes. In Methods in Molecular Biology; Humana Press: New York, NY, USA, 2017; Volume 1566, pp. 25-36.

61. Russell, A.P.; Crisan, M.; Léger, B.; Corselli, M.; McAinch, A.J.; O’Brien, P.E.; Cameron-Smith, D.; Péault, B.; Casteilla, L.; Giacobino, J.P. Brown adipocyte progenitor population is modified in obese and diabetic skeletal muscle. Int. J. Obes. 2012, 36, 155-158. [CrossRef]

62. Raajendiran, A.; Ooi, G.; Bayliss, J.; O’Brien, P.E.; Schittenhelm, R.B.; Clark, A.K.; Taylor, R.A.; Rodeheffer, M.S.; Burton, P.R.; Watt, M.J. Identification of Metabolically Distinct Adipocyte Progenitor Cells in Human Adipose Tissues. Cell Rep. 2019, 27, 1528-1540.e7. [CrossRef]

63. Oguri, Y.; Shinoda, K.; Kim, H.; Alba, D.L.; Bolus, W.R.; Wang, Q.; Brown, Z.; Pradhan, R.N.; Tajima, K.; Yoneshiro, T.; et al. CD81 Controls Beige Fat Progenitor Cell Growth and Energy Balance via FAK Signaling. Cell 2020, 182, 563-577.e20. [CrossRef] 
64. Maumus, M.; Peyrafitte, J.A.; D’Angelo, R.; Fournier-Wirth, C.; Bouloumié, A.; Casteilla, L.; Sengenès, C.; Bourin, P. Native human adipose stromal cells: Localization, morphology and phenotype. Int. J. Obes. 2011, 35, 1141-1153. [CrossRef]

65. Turley, S.J.; Cremasco, V.; Astarita, J.L. Immunological hallmarks of stromal cells in the tumour microenvironment. Nat. Rev. Immunol. 2015, 15, 669-682. [CrossRef] [PubMed]

66. Traktuev, D.O.; Merfeld-Clauss, S.; Li, J.; Kolonin, M.; Arap, W.; Pasqualini, R.; Johnstone, B.H.; March, K.L. A population of multipotent CD34-positive adipose stromal cells share pericyte and mesenchymal surface markers, reside in a periendothelial location, and stabilize endothelial networks. Circ. Res. 2008, 102, 77-85. [CrossRef]

67. Lee, Y.H.; Petkova, A.P.; Mottillo, E.P.; Granneman, J.G. In vivo identification of bipotential adipocyte progenitors recruited by ß3-adrenoceptor activation and high-fat feeding. Cell Metab. 2012, 15, 480-491. [CrossRef]

68. Daquinag, A.C.; Tseng, C.; Salameh, A.; Zhang, Y.; Amaya-Manzanares, F.; Dadbin, A.; Florez, F.; Xu, Y.; Tong, Q.; Kolonin, M.G. Depletion of white adipocyte progenitors induces beige adipocyte differentiation and suppresses obesity development. Cell Death Differ. 2015, 22, 351-363. [CrossRef]

69. Gao, Z.; Daquinag, A.C.; Su, F.; Snyder, B.; Kolonin, M.G. PDGFR $\alpha /$ PDGFR $\beta$ signaling balance modulates progenitor cell differentiation into white and beige adipocytes. Development 2018, 145. [CrossRef] [PubMed]

70. Chen, Y.; Ikeda, K.; Yoneshiro, T.; Scaramozza, A.; Tajima, K.; Wang, Q.; Kim, K.; Shinoda, K.; Sponton, C.H.; Brown, Z.; et al. Thermal stress induces glycolytic beige fat formation via a myogenic state. Nature 2019, 565, 180-185. [CrossRef] [PubMed]

71. Farmer, S.R. Transcriptional control of adipocyte formation. Cell Metab. 2006, 4, 263-273. [CrossRef] [PubMed]

72. Rangwala, S.M.; Lazar, M.A. Transcriptional control of adipogenesis. Annu. Rev. Nutr. 2000, 20, 535-559. [CrossRef]

73. Siersbæk, R.; Mandrup, S. Transcriptional networks controlling adipocyte differentiation. Cold Spring Harb. Symp. Quant. Biol. 2011, 76, 247-255. [CrossRef]

74. Rajakumari, S.; Wu, J.; Ishibashi, J.; Lim, H.W.; Giang, A.H.; Won, K.J.; Reed, R.R.; Seale, P. EBF2 determines and maintains brown adipocyte identity. Cell Metab. 2013, 17, 562-574. [CrossRef] [PubMed]

75. Shinoda, K.; Luijten, I.H.N.; Hasegawa, Y.; Hong, H.; Sonne, S.B.; Kim, M.; Xue, R.; Chondronikola, M.; Cypess, A.M.; Tseng, Y.H.; et al. Genetic and functional characterization of clonally derived adult human brown adipocytes. Nat. Med. 2015, 21, 389-394. [CrossRef] [PubMed]

76. Stine, R.R.; Shapira, S.N.; Lim, H.W.; Ishibashi, J.; Harms, M.; Won, K.J.; Seale, P. EBF2 promotes the recruitment of beige adipocytes in white adipose tissue. Mol. Metab. 2016, 5, 57-65. [CrossRef]

77. Park, J.H.; Kang, H.J.; Kang, S.I.; Lee, J.E.; Hur, J.; Ge, K.; Mueller, E.; Li, H.; Lee, B.C.; Lee, S.B. A Multifunctional protein, EWS, is essential for early brown fat lineage determination. Dev. Cell 2013, 26, 393-404. [CrossRef]

78. Park, J.H.; Kang, H.J.; Lee, Y.K.; Kang, H.; Kim, J.; Chung, J.H.; Chang, J.S.; McPherron, A.C.; Lee, S.B. Inactivation of EWS reduces PGC-1 $\alpha$ protein stability and mitochondrial homeostasis. Proc. Natl. Acad. Sci. USA 2015, 112, 6074-6079. [CrossRef] [PubMed]

79. Rabiee, A.; Plucińska, K.; Isidor, M.S.; Brown, E.L.; Tozzi, M.; Sidoli, S.; Petersen, P.S.S.; Agueda-Oyarzabal, M.; Torsetnes, S.B.; Chehabi, G.N.; et al. White adipose remodeling during browning in mice involves YBX1 to drive thermogenic commitment. Mol. Metab. 2021, 44, 101137. [CrossRef]

80. Ma, X.; Xu, L.; Alberobello, A.T.; Gavrilova, O.; Bagattin, A.; Skarulis, M.; Liu, J.; Finkel, T.; Mueller, E. Celastrol protects against obesity and metabolic dysfunction through activation of a HSF1-PGC1 $\alpha$ transcriptional axis. Cell Metab. 2015, 22, 695-708. [CrossRef]

81. Liu, J.; Lee, J.; Hernandez, M.A.S.; Mazitschek, R.; Ozcan, U. Treatment of obesity with celastrol. Cell 2015, 161, 999-1011. [CrossRef]

82. Zhou, H.; Wan, B.; Grubisic, I.; Kaplan, T.; Tjian, R. TAF7L modulates brown adipose tissue formation. Elife 2014, 2014. [CrossRef]

83. Zhang, H.; Huang, Y.; Lee, H.J.; Jin, W. Zic1 negatively regulates brown adipogenesis in C3H10T1/2 cells. Sci. Bull. 2015, 60, 1033-1035. [CrossRef]

84. Perugini, J.; Bordoni, L.; Venema, W.; Acciarini, S.; Cinti, S.; Gabbianelli, R.; Giordano, A. Zic1 mRNA is transiently upregulated in subcutaneous fat of acutely cold-exposed mice. J. Cell. Physiol. 2019, 234, 2031-2036. [CrossRef]

85. Plaisier, C.L.; Bennett, B.J.; He, A.; Guan, B.; Lusis, A.J.; Reue, K.; Vergnes, L. Zbtb16 has a role in brown adipocyte bioenergetics. Nutr. Diabetes 2012, 2, e46. [CrossRef]

86. Wei, S.; Zhang, M.; Zheng, Y.; Yan, P. ZBTB16 Overexpression Enhances White Adipogenesis and Induces Brown-Like Adipocyte Formation of Bovine White Intramuscular Preadipocytes. Cell. Physiol. Biochem. 2018, 48, 2528-2538. [CrossRef] [PubMed]

87. Kita, M.; Nakae, J.; Kawano, Y.; Asahara, H.; Takemori, H.; Okado, H.; Itoh, H. Zfp238 Regulates the Thermogenic Program in Cooperation with Foxo1. iScience 2019, 12, 87-101. [CrossRef]

88. Seale, P.; Kajimura, S.; Yang, W.; Chin, S.; Rohas, L.M.; Uldry, M.; Tavernier, G.; Langin, D.; Spiegelman, B.M. Transcriptional Control of Brown Fat Determination by PRDM16. Cell Metab. 2007, 6, 38-54. [CrossRef] [PubMed]

89. Ohno, H.; Shinoda, K.; Ohyama, K.; Sharp, L.Z.; Kajimura, S. EHMT1 controls brown adipose cell fate and thermogenesis through the PRDM16 complex. Nature 2013, 504, 163-167. [CrossRef]

90. Kajimura, S.; Seale, P.; Tomaru, T.; Erdjument-Bromage, H.; Cooper, M.P.; Ruas, J.L.; Chin, S.; Tempst, P.; Lazar, M.A.; Spiegelman, B.M. Regulation of the brown and white fat gene programs through a PRDM16/CtBP transcriptional complex. Genes Dev. 2008, 22, 1397-1409. [CrossRef]

91. Harms, M.J.; Ishibashi, J.; Wang, W.; Lim, H.W.; Goyama, S.; Sato, T.; Kurokawa, M.; Won, K.J.; Seale, P. Prdm16 is required for the maintenance of brown adipocyte identity and function in adult mice. Cell Metab. 2014, 19, 593-604. [CrossRef] [PubMed] 
92. Kajimura, S.; Seale, P.; Kubota, K.; Lunsford, E.; Frangioni, J.V.; Gygi, S.P.; Spiegelman, B.M. Initiation of myoblast to brown fat switch by a PRDM16-C/EBP- $\beta$ transcriptional complex. Nature 2009, 460, 1154-1158. [CrossRef]

93. Harms, M.J.; Lim, H.W.; Ho, Y.; Shapira, S.N.; Ishibashi, J.; Rajakumari, S.; Steger, D.J.; Lazar, M.A.; Won, K.J.; Seale, P. PRDM16 binds MED1 and controls chromatin architecture to determine a brown fat transcriptional program. Genes Dev. 2015, 29, 298-307. [CrossRef]

94. Iida, S.; Chen, W.; Nakadai, T.; Ohkuma, Y.; Roeder, R.G. PRDM16 enhances nuclear receptordependent transcription of the brown fat-specific Ucp1 gene through interactions with mediator subunit MED1. Genes Dev. 2015, 29, 308-321. [CrossRef] [PubMed]

95. Kissig, M.; Ishibashi, J.; Harms, M.J.; Lim, H.; Stine, R.R.; Won, K.; Seale, P. PRDM16 represses the type I interferon response in adipocytes to promote mitochondrial and thermogenic programing. EMBO J. 2017, 36, 1528-1542. [CrossRef]

96. Seale, P.; Conroe, H.M.; Estall, J.; Kajimura, S.; Frontini, A.; Ishibashi, J.; Cohen, P.; Cinti, S.; Spiegelman, B.M. Prdm16 determines the thermogenic program of subcutaneous white adipose tissue in mice. J. Clin. Investig. 2011, 121, 96-105. [CrossRef] [PubMed]

97. Cohen, P.; Levy, J.D.; Zhang, Y.; Frontini, A.; Kolodin, D.P.; Svensson, K.J.; Lo, J.C.; Zeng, X.; Ye, L.; Khandekar, M.J.; et al. Ablation of PRDM16 and beige adipose causes metabolic dysfunction and a subcutaneous to visceral fat switch. Cell 2014, 156, 304-316. [CrossRef]

98. Puigserver, P.; Wu, Z.; Park, C.W.; Graves, R.; Wright, M.; Spiegelman, B.M. A cold-inducible coactivator of nuclear receptors linked to adaptive thermogenesis. Cell 1998, 92, 829-839. [CrossRef]

99. Tiraby, C.; Tavernier, G.; Lefort, C.; Larrouy, D.; Bouillaud, F.; Ricquier, D.; Langin, D. Acquirement of brown fat cell features by human white adipocytes. J. Biol. Chem. 2003, 278, 33370-33376. [CrossRef]

100. Kong, X.; Banks, A.; Liu, T.; Kazak, L.; Rao, R.R.; Cohen, P.; Wang, X.; Yu, S.; Lo, J.C.; Tseng, Y.H.; et al. IRF4 is a key thermogenic transcriptional partner of PGC-1 $\alpha$. Cell 2014, 158, 69-83. [CrossRef]

101. Chen, W.; Yang, Q.; Roeder, R.G. Dynamic Interactions and Cooperative Functions of PGC-1 $\alpha$ and MED1 in TR $\alpha$-Mediated Activation of the Brown-Fat-Specific UCP-1 Gene. Mol. Cell 2009, 35, 755-768. [CrossRef] [PubMed]

102. Lin, J.; Handschin, C.; Spiegelman, B.M. Metabolic control through the PGC-1 family of transcription coactivators. Cell Metab. 2005, 1, 361-370. [CrossRef]

103. Wu, Z.; Puigserver, P.; Andersson, U.; Zhang, C.; Adelmant, G.; Mootha, V.; Troy, A.; Cinti, S.; Lowell, B.; Scarpulla, R.C.; et al. Mechanisms controlling mitochondrial biogenesis and respiration through the thermogenic coactivator PGC-1. Cell 1999, 98, 115-124. [CrossRef]

104. Lehman, J.J.; Barger, P.M.; Kovacs, A.; Saffitz, J.E.; Medeiros, D.M.; Kelly, D.P. Peroxisome proliferator-activated receptor $\gamma$ coactivator-1 promotes cardiac mitochondrial biogenesis. J. Clin. Investig. 2000, 106, 847-856. [CrossRef]

105. Lin, J.; Wu, P.H.; Tarr, P.T.; Lindenberg, K.S.; St-Pierre, J.; Zhang, C.Y.; Mootha, V.K.; Jäger, S.; Vianna, C.R.; Reznick, R.M.; et al. Defects in adaptive energy metabolism with CNS-linked hyperactivity in PGC-1 $\alpha$ null mice. Cell 2004, 119, 121-135. [CrossRef] [PubMed]

106. Uldry, M.; Yang, W.; St-Pierre, J.; Lin, J.; Seale, P.; Spiegelman, B.M. Complementary action of the PGC-1 coactivators in mitochondrial biogenesis and brown fat differentiation. Cell Metab. 2006, 3, 333-341. [CrossRef]

107. Kleiner, S.; Mepani, R.J.; Laznik, D.; Ye, L.; Jurczak, M.J.; Jornayvaz, F.R.; Estall, J.L.; Bhowmick, D.C.; Shulman, G.I.; Spiegelman, B.M. Development of insulin resistance in mice lacking PGC-1 $\alpha$ in adipose tissues. Proc. Natl. Acad. Sci. USA 2012, 109, 9635-9640. [CrossRef] [PubMed]

108. Dempersmier, J.; Sambeat, A.; Gulyaeva, O.; Paul, S.M.; Hudak, C.S.S.; Raposo, H.F.; Kwan, H.Y.; Kang, C.; Wong, R.H.F.; Sul, H.S. Cold-inducible Zfp516 activates UCP1 transcription to promote browning of white fat and development of brown fat. Mol. Cell 2015, 57, 235-246. [CrossRef]

109. Cao, W.; Daniel, K.W.; Robidoux, J.; Puigserver, P.; Medvedev, A.V.; Bai, X.; Floering, L.M.; Spiegelman, B.M.; Collins, S. p38 Mitogen-Activated Protein Kinase Is the Central Regulator of Cyclic AMP-Dependent Transcription of the Brown Fat Uncoupling Protein 1 Gene. Mol. Cell. Biol. 2004, 24, 3057-3067. [CrossRef]

110. Cederberg, A.; Gronning, L.M.; Ahrén, B.; Taskén, K.; Carlsson, P.; Enerbäck, S. FOXC2 is a winged helix gene that counteracts obesity, hypertriglyceridemia, and diet-induced insulin resistance. Cell 2001, 106, 563-573. [CrossRef]

111. Davis, K.E.; Moldes, M.; Farmer, S.R. The forkhead transcription factor FoxC2 inhibits white adipocyte differentiation. J. Biol. Chem. 2004, 279, 42453-42461. [CrossRef]

112. Loft, A.; Forss, I.; Siersbæk, M.S.; Schmidt, S.F.; Larsen, A.S.B.; Madsen, J.G.S.; Pisani, D.F.; Nielsen, R.; Aagaard, M.M.; Mathison, A.; et al. Browning of human adipocytes requires KLF11 and reprogramming of PPAR $\gamma$ superenhancers. Genes Dev. 2015, 29, 7-22. [CrossRef] [PubMed]

113. Fan, H.; Zhang, Y.; Zhang, J.; Yao, Q.; Song, Y.; Shen, Q.; Lin, J.; Gao, Y.; Wang, X.; Zhang, L.; et al. Cold-inducible Klf9 regulates thermogenesis of brown and beige fat. Diabetes 2020, 69, 2603-2618. [CrossRef]

114. Yang, Z.-F.; Drumea, K.; Mott, S.; Wang, J.; Rosmarin, A.G. GABP Transcription Factor (Nuclear Respiratory Factor 2) Is Required for Mitochondrial Biogenesis. Mol. Cell. Biol. 2014, 34, 3194-3201. [CrossRef] [PubMed]

115. Mootha, V.K.; Handschin, C.; Arlow, D.; Xie, X.; St. Pierre, J.; Sihag, S.; Yang, W.; Altshuler, D.; Puigserver, P.; Patterson, N.; et al. Err $\alpha$ and Gabpa/b specify PGC-1 $\alpha$-dependent oxidative phosphorylation gene expression that is altered in diabetic muscle. Proc. Natl. Acad. Sci. USA 2004, 101, 6570-6575. [CrossRef] [PubMed]

116. Gantner, M.L.; Hazen, B.C.; Eury, E.; Brown, E.L.; Kralli, A. Complementary roles of estrogen-related receptors in brown adipocyte thermogenic function. Endocrinology 2016, 157, 4770-4781. [CrossRef] 
117. Gerhart-Hines, Z.; Feng, D.; Emmett, M.J.; Everett, L.J.; Loro, E.; Briggs, E.R.; Bugge, A.; Hou, C.; Ferrara, C.; Seale, P.; et al. The nuclear receptor Rev-erb $\alpha$ controls circadian thermogenic plasticity. Nature 2013, 503, 410-413. [CrossRef]

118. Nam, D.; Chatterjee, S.; Yin, H.; Liu, R.; Lee, J.; Yechoor, V.K.; Ma, K. Novel function of rev-erb $\alpha$ in promoting brown adipogenesis. Sci. Rep. 2015, 5. [CrossRef] [PubMed]

119. Brown, E.L.; Hazen, B.C.; Eury, E.; Wattez, J.S.; Gantner, M.L.; Albert, V.; Chau, S.; Sanchez-Alavez, M.; Conti, B.; Kralli, A. Estrogen-Related Receptors Mediate the Adaptive Response of Brown Adipose Tissue to Adrenergic Stimulation. iScience 2018, 2, 221-237. [CrossRef] [PubMed]

120. Wang, B.; Fu, X.; Liang, X.; Deavila, J.M.; Wang, Z.; Zhao, L.; Tian, Q.; Zhao, J.; Gomez, N.A.; Trombetta, S.C.; et al. Retinoic acid induces white adipose tissue browning by increasing adipose vascularity and inducing beige adipogenesis of PDGFR $\alpha+$ adipose progenitors. Cell Discov. 2017, 3. [CrossRef] [PubMed]

121. Kumar, N.; Liu, D.; Wang, H.; Robidoux, J.; Collins, S. Orphan nuclear receptor NOR-1 enhances $3^{\prime}, 5^{\prime}$-cyclic adenosine $5^{\prime}-$ monophosphate-dependent uncoupling protein-1 gene transcription. Mol. Endocrinol. 2008, 22, 1057-1064. [CrossRef]

122. Bi, P.; Shan, T.; Liu, W.; Yue, F.; Yang, X.; Liang, X.R.; Wang, J.; Li, J.; Carlesso, N.; Liu, X.; et al. Inhibition of Notch signaling promotes browning of white adipose tissue and ameliorates obesity. Nat. Med. 2014, 20, 911-918. [CrossRef]

123. Claussnitzer, M.; Dankel, S.N.; Kim, K.-H.; Quon, G.; Meuleman, W.; Haugen, C.; Glunk, V.; Sousa, I.S.; Beaudry, J.L.; Puviindran, V.; et al. FTO Obesity Variant Circuitry and Adipocyte Browning in Humans. N. Engl. J. Med. 2015, 373, 895-907. [CrossRef] [PubMed]

124. Christian, M.; Kiskinis, E.; Debevec, D.; Leonardsson, G.; White, R.; Parker, M.G. RIP140-Targeted Repression of Gene Expression in Adipocytes. Mol. Cell. Biol. 2005, 25, 9383-9391. [CrossRef]

125. Powelka, A.M.; Seth, A.; Virbasius, J.V.; Kiskinis, E.; Nicoloro, S.M.; Guilherme, A.; Tang, X.; Straubhaar, J.; Cherniack, A.D.; Parker, M.G.; et al. Suppression of oxidative metabolism and mitochondrial biogenesis by the transcriptional corepressor RIP140 in mouse adipocytes. J. Clin. Investig. 2006, 116, 125-136. [CrossRef] [PubMed]

126. Leonardsson, G.; Steel, J.H.; Christian, M.; Pocock, V.; Milligan, S.; Bell, J.; So, P.W.; Medina-Gomez, G.; Vidal-Puig, A.; White, R.; et al. Nuclear receptor corepressor RIP140 regulates fat accumulation. Proc. Natl. Acad. Sci. USA 2004, 101, 8437-8442. [CrossRef] [PubMed]

127. Pearson, S.; Loft, A.; Rajbhandari, P.; Simcox, J.; Lee, S.; Tontonoz, P.; Mandrup, S.; Villanueva, C.J. Loss of TLE3 promotes the mitochondrial program in beige adipocytes and improves glucose metabolism. Genes Dev. 2019, 33, 747-762. [CrossRef]

128. Gupta, R.K.; Arany, Z.; Seale, P.; Mepani, R.J.; Ye, L.; Conroe, H.M.; Roby, Y.A.; Kulaga, H.; Reed, R.R.; Spiegelman, B.M. Transcriptional control of preadipocyte determination by Zfp423. Nature 2010, 464, 619-623. [CrossRef]

129. Shao, M.; Ishibashi, J.; Kusminski, C.M.; Wang, Q.A.; Hepler, C.; Vishvanath, L.; MacPherson, K.A.; Spurgin, S.B.; Sun, K.; Holland, W.L.; et al. Zfp423 Maintains White Adipocyte Identity through Suppression of the Beige Cell Thermogenic Gene Program. Cell Metab. 2016, 23, 1167-1184. [CrossRef]

130. Mori, M.; Nakagami, H.; Rodriguez-Araujo, G.; Nimura, K.; Kaneda, Y. Essential role for miR-196a in brown adipogenesis of white fat progenitor cells. PLoS Biol. 2012, 10, e1001314. [CrossRef]

131. Ng, Y.; Tan, S.X.; Chia, S.Y.; Tan, H.Y.A.; Gun, S.Y.; Sun, L.; Hong, W.; Han, W. HOXC10 suppresses browning of white adipose tissues. Exp. Mol. Med. 2017, 49, e292. [CrossRef]

132. Pan, D.; Fujimoto, M.; Lopes, A.; Wang, Y.X. Twist-1 Is a PPAR $\delta$-Inducible, Negative-Feedback Regulator of PGC-1 $\alpha$ in Brown Fat Metabolism. Cell 2009, 137, 73-86. [CrossRef]

133. Xu, L.; Panel, V.; Ma, X.; Du, C.; Hugendubler, L.; Gavrilova, O.; Liu, A.; McLaughlin, T.; Kaestner, K.H.; Mueller, E. The Winged Helix Transcription Factor Foxa3 Regulates Adipocyte Differentiation and Depot-Selective Fat Tissue Expansion. Mol. Cell. Biol. 2013, 33, 3392-3399. [CrossRef] [PubMed]

134. Ma, X.; Xu, L.; Gavrilova, O.; Mueller, E. Role of forkhead box protein A3 in age-associated metabolic decline. Proc. Natl. Acad. Sci. USA 2014, 111, 14289-14294. [CrossRef]

135. Cheng, Z.; Tao, Z.; Liu, L.; Zheng, L. FoxO1 regulates beige adipogenesis and adiposity via autophagy. FASEB J. $2019,33$. [CrossRef]

136. Ioannilli, L.; Ciccarone, F.; Ciriolo, M.R. Adipose Tissue and FoxO1: Bridging Physiology and Mechanisms. Cells 2020, 9 , 849. [CrossRef]

137. Liu, P.; Huang, S.; Ling, S.; Xu, S.; Wang, F.; Zhang, W.; Zhou, R.; He, L.; Xia, X.; Yao, Z.; et al. Foxp1 controls brown/beige adipocyte differentiation and thermogenesis through regulating $\beta 3-A R$ desensitization. Nat. Commun. 2019, 10, 1-12. [CrossRef]

138. Calo, E.; Quintero-Estades, J.A.; Danielian, P.S.; Nedelcu, S.; Berman, S.D.; Lees, J.A. Rb regulates fate choice and lineage commitment in vivo. Nature 2010, 466, 1110-1114. [CrossRef]

139. Yadav, H.; Quijano, C.; Kamaraju, A.K.; Gavrilova, O.; Malek, R.; Chen, W.; Zerfas, P.; Zhigang, D.; Wright, E.C.; Stuelten, C.; et al. Protection from obesity and diabetes by blockade of TGF- $\beta /$ Smad3 signaling. Cell Metab. 2011, 14, 67-79. [CrossRef] [PubMed]

140. Laurila, P.P.; Soronen, J.; Kooijman, S.; Forsström, S.; Boon, M.R.; Surakka, I.; Kaiharju, E.; Coomans, C.P.; Van Den Berg, S.A.A.; Autio, A.; et al. USF1 deficiency activates brown adipose tissue and improves cardiometabolic health. Sci. Transl. Med. 2016, 8, 323ra13. [CrossRef] [PubMed]

141. McDonald, M.E.; Li, C.; Bian, H.; Smith, B.D.; Layne, M.D.; Farmer, S.R. Myocardin-related transcription factor a regulates conversion of progenitors to beige adipocytes. Cell 2015, 160, 105-118. [CrossRef] 
142. Wang, H.; Zhang, Y.; Yehuda-Shnaidman, E.; Medvedev, A.V.; Kumar, N.; Daniel, K.W.; Robidoux, J.; Czech, M.P.; Mangelsdorf, D.J.; Collins, S. Liver X Receptor $\alpha$ Is a Transcriptional Repressor of the Uncoupling Protein 1 Gene and the Brown Fat Phenotype. Mol. Cell. Biol. 2008, 28, 2187-2200. [CrossRef] [PubMed]

143. Scimè, A.; Grenier, G.; Huh, M.S.; Gillespie, M.A.; Bevilacqua, L.; Harper, M.E.; Rudnicki, M.A. Rb and p107 regulate preadipocyte differentiation into white versus brown fat through repression of PGC-1 $\alpha$. Cell Metab. 2005, 2, 283-295. [CrossRef]

144. De Sousa, M.; Porras, D.P.; Perry, C.G.R.; Seale, P.; Scimè, A. P107 is a crucial regulator for determining the adipocyte lineage fate choices of stem cells. Stem Cells 2014, 32, 1323-1336. [CrossRef]

145. Cunarro, J.; Buque, X.; Casado, S.; Lugilde, J.; Vidal, A.; Mora, A.; Sabio, G.; Nogueiras, R.; Aspichueta, P.; Diéguez, C.; et al. p107 Deficiency Increases Energy Expenditure by Inducing Brown-Fat Thermogenesis and Browning of White Adipose Tissue. Mol. Nutr. Food Res. 2019, 63, 1801096. [CrossRef]

146. Vernochet, C.; Peres, S.B.; Davis, K.E.; McDonald, M.E.; Qiang, L.; Wang, H.; Scherer, P.E.; Farmer, S.R. C/EBP $\alpha$ and the Corepressors CtBP1 and CtBP2 Regulate Repression of Select Visceral White Adipose Genes during Induction of the Brown Phenotype in White Adipocytes by Peroxisome Proliferator-Activated Receptor $\gamma$ Agonists. Mol. Cell. Biol. 2009, 29, 4714-4728. [CrossRef] [PubMed]

147. Siersbaek, M.S.; Loft, A.; Aagaard, M.M.; Nielsen, R.; Schmidt, S.F.; Petrovic, N.; Nedergaard, J.; Mandrup, S. Genome-Wide Profiling of Peroxisome Proliferator-Activated Receptor $\gamma$ in Primary Epididymal, Inguinal, and Brown Adipocytes Reveals Depot-Selective Binding Correlated with Gene Expression. Mol. Cell. Biol. 2012, 32, 3452-3463. [CrossRef]

148. Roh, H.C.; Tsai, L.T.Y.; Shao, M.; Tenen, D.; Shen, Y.; Kumari, M.; Lyubetskaya, A.; Jacobs, C.; Dawes, B.; Gupta, R.K.; et al. Warming Induces Significant Reprogramming of Beige, but Not Brown, Adipocyte Cellular Identity. Cell Metab. 2018, 27, 1121-1137.e5. [CrossRef] [PubMed]

149. Lai, B.; Lee, J.E.; Jang, Y.; Lifeng, W.; Peng, W.; Ge, K. MLL3/MLL4 are required for CBP/p300 binding on enhancers and super-enhancer formation in brown adipogenesis. Nucleic Acids Res. 2017, 45, 6388-6403. [CrossRef] [PubMed]

150. Pan, D.; Huang, L.; Zhu, L.J.; Zou, T.; Ou, J.; Zhou, W.; Wang, Y.X. Jmjd3-Mediated H3K27me3 Dynamics Orchestrate Brown Fat Development and Regulate White Fat Plasticity. Dev. Cell 2015, 35, 568-583. [CrossRef]

151. Li, F.; Wu, R.; Cui, X.; Zha, L.; Yu, L.; Shi, H.; Xue, B. Histone deacetylase 1 (HDAC1) negatively regulates thermogenic program in brown adipocytes via coordinated regulation of histone $\mathrm{H} 3$ lysine 27 (H3K27) deacetylation and methylation. J. Biol. Chem. 2016, 291, 4523-4536. [CrossRef] [PubMed]

152. Nic-Can, G.I.; Rodas-Junco, B.A.; Carrillo-Cocom, L.M.; Zepeda-Pedreguera, A.; Peñaloza-Cuevas, R.; Aguilar-Ayala, F.J.; Rojas-Herrera, R.A. Epigenetic regulation of adipogenic differentiation by histone lysine demethylation. Int. J. Mol. Sci. 2019, 20, 3918. [CrossRef]

153. Tanimura, K.; Suzuki, T.; Vargas, D.; Shibata, H.; Inagaki, T. Epigenetic regulation of beige adipocyte fate by histone methylation. Endocr. J. 2019, 66, 115-125. [CrossRef] [PubMed]

154. Zha, L.; Li, F.; Wu, R.; Artinian, L.; Rehder, V.; Yu, L.; Liang, H.; Xue, B.; Shi, H. The histone demethylase UTX promotes brown adipocyte thermogenic program via coordinated regulation of H3K27 demethylation and acetylation. J. Biol. Chem. 2015, 290, 25151-25163. [CrossRef]

155. Abe, Y.; Rozqie, R.; Matsumura, Y.; Kawamura, T.; Nakaki, R.; Tsurutani, Y.; Tanimura-Inagaki, K.; Shiono, A.; Magoori, K.; Nakamura, K.; et al. JMJD1A is a signal-sensing scaffold that regulates acute chromatin dynamics via SWI/SNF association for thermogenesis. Nat. Commun. 2015, 6, 1-14. [CrossRef]

156. Sambeat, A.; Gulyaeva, O.; Dempersmier, J.; Tharp, K.M.; Stahl, A.; Paul, S.M.; Sul, H.S. LSD1 Interacts with Zfp516 to Promote UCP1 Transcription and Brown Fat Program. Cell Rep. 2016, 15, 2536-2549. [CrossRef] [PubMed]

157. Lee, J.E.; Wang, C.; Xu, S.; Cho, Y.W.; Wang, L.; Feng, X.; Baldridge, A.; Sartorelli, V.; Zhuang, L.; Peng, W.; et al. H3K4 mono- And di-methyltransferase MLL4 is required for enhancer activation during cell differentiation. eLife 2013, 2013, e01503. [CrossRef] [PubMed]

158. Emmett, M.J.; Lim, H.W.; Jager, J.; Richter, H.J.; Adlanmerini, M.; Peed, L.C.; Briggs, E.R.; Steger, D.J.; Ma, T.; Sims, C.A.; et al. Histone deacetylase 3 prepares brown adipose tissue for acute thermogenic challenge. Nature 2017, 546, 544-548. [CrossRef] [PubMed]

159. Nanduri, R. Epigenetic Regulators of White Adipocyte Browning. Epigenomes 2021, 5, 3. [CrossRef]

160. Liu, T.; Mi, L.; Xiong, J.; Orchard, P.; Yu, Q.; Yu, L.; Zhao, X.Y.; Meng, Z.X.; Parker, S.C.J.; Lin, J.D.; et al. BAF60a deficiency uncouples chromatin accessibility and cold sensitivity from white fat browning. Nat. Commun. 2020, 11, 1-15. [CrossRef] [PubMed]

161. Xiao, H.; Kang, S. The role of DNA methylation in thermogenic adipose biology. Epigenetics 2019, 14, 837-843. [CrossRef]

162. Lim, Y.C.; Chia, S.Y.; Jin, S.; Han, W.; Ding, C.; Sun, L. Dynamic DNA methylation landscape defines brown and white cell specificity during adipogenesis. Mol. Metab. 2016, 5, 1033-1041. [CrossRef]

163. Vinet, L.; Zhedanov, A. A "missing" family of classical orthogonal polynomials. J. Phys. A Math. Theor. $2011,44,085201$. [CrossRef]

164. Damal Villivalam, S.; You, D.; Kim, J.; Lim, H.W.; Xiao, H.; Zushin, P.J.H.; Oguri, Y.; Amin, P.; Kang, S. TET1 is a beige adipocyte-selective epigenetic suppressor of thermogenesis. Nat. Commun. 2020, 11, 1-14. [CrossRef] [PubMed]

165. Treiber, T.; Treiber, N.; Meister, G. Regulation of microRNA biogenesis and its crosstalk with other cellular pathways. Nat. Rev. Mol. Cell Biol. 2019, 20, 5-20. [CrossRef] [PubMed] 
166. Mori, M.A.; Thomou, T.; Boucher, J.; Lee, K.Y.; Lallukka, S.; Kim, J.K.; Torriani, M.; Yki-Järvinen, H.; Grinspoon, S.K.; Cypess, A.M.; et al. Altered miRNA processing disrupts brown/white adipocyte determination and associates with lipodystrophy. J. Clin. Investig. 2014, 124, 3339-3351. [CrossRef] [PubMed]

167. Brandão, B.B.; Guerra, B.A.; Mori, M.A. Shortcuts to a functional adipose tissue: The role of small non-coding RNAs. Redox Biol. 2017, 12, 82-102. [CrossRef]

168. Yin, H.; Pasut, A.; Soleimani, V.D.; Bentzinger, C.F.; Antoun, G.; Thorn, S.; Seale, P.; Fernando, P.; Van Ijcken, W.; Grosveld, F.; et al. MicroRNA-133 controls brown adipose determination in skeletal muscle satellite cells by targeting Prdm16. Cell Metab. 2013, 17, 210-224. [CrossRef]

169. Oliverio, M.; Schmidt, E.; Mauer, J.; Baitzel, C.; Hansmeier, N.; Khani, S.; Konieczka, S.; Pradas-Juni, M.; Brodesser, S.; Van, T.M.; et al. Dicer1-miR-328-Bace1 signalling controls brown adipose tissue differentiation and function. Nat. Cell Biol. 2016, 18, 328-336. [CrossRef] [PubMed]

170. Hu, F.; Wang, M.; Xiao, T.; Yin, B.; He, L.; Meng, W.; Dong, M.; Liu, F. MiR-30 promotes thermogenesis and the development of beige fat by targeting RIP140. Diabetes 2015, 64, 2056-2068. [CrossRef]

171. Lai, S.; Du, K.; Shi, Y.; Li, C.; Wang, G.; Hu, S.; Jia, X.; Wang, J.; Chen, S. Long non-coding rnas in brown adipose tissue. Diabetes Metab. Syndr. Obes. Targets Ther. 2020, 13, 3193. [CrossRef]

172. Statello, L.; Guo, C.J.; Chen, L.L.; Huarte, M. Gene regulation by long non-coding RNAs and its biological functions. Nat. Rev. Mol. Cell Biol. 2021, 1-23. [CrossRef]

173. Zhao, X.Y.; Li, S.; Wang, G.X.; Yu, Q.; Lin, J.D. A Long noncoding RNA transcriptional regulatory circuit drives thermogenic adipocyte differentiation. Mol. Cell 2014, 55, 372-382. [CrossRef] [PubMed]

174. Li, S.; Mi, L.; Yu, L.; Yu, Q.; Liu, T.; Wang, G.X.; Zhao, X.Y.; Wu, J.; Lin, J.D. Zbtb7b engages the long noncoding RNA Blnc1 to drive brown and beige fat development and thermogenesis. Proc. Natl. Acad. Sci. USA 2017, 114, E7111-E7120. [CrossRef]

175. Mi, L.; Zhao, X.Y.; Li, S.; Yang, G.; Lin, J.D. Conserved function of the long noncoding RNA Blnc1 in brown adipocyte differentiation. Mol. Metab. 2017, 6, 101-110. [CrossRef]

176. Bai, Z.; Chai, X.R.; Yoon, M.J.; Kim, H.J.; Lo, K.A.; Zhang, Z.C.; Xu, D.; Siang, D.T.C.; Walet, A.C.E.; Xu, S.H.; et al. Dynamic transcriptome changes during adipose tissue energy expenditure reveal critical roles for long noncoding RNA regulators. PLoS Biol. 2017, 15. [CrossRef]

177. Min, S.Y.; Kady, J.; Nam, M.; Rojas-Rodriguez, R.; Berkenwald, A.; Kim, J.H.; Noh, H.L.; Kim, J.K.; Cooper, M.P.; Fitzgibbons, T.; et al. Human "brite/beige" adipocytes develop from capillary networks, and their implantation improves metabolic homeostasis in mice. Nat. Med. 2016, 22, 312-318. [CrossRef]

178. Van Tran, K.; Gealekman, O.; Frontini, A.; Zingaretti, M.C.; Morroni, M.; Giordano, A.; Smorlesi, A.; Perugini, J.; De Matteis, R.; Sbarbati, A.; et al. The vascular endothelium of the adipose tissue gives rise to both white and brown fat cells. Cell Metab. 2012, 15, 222-229. [CrossRef] [PubMed]

179. Barbatelli, G.; Murano, I.; Madsen, L.; Hao, Q.; Jimenez, M.; Kristiansen, K.; Giacobino, J.P.; De Matteis, R.; Cinti, S. The emergence of cold-induced brown adipocytes in mouse white fat depots is determined predominantly by white to brown adipocyte transdifferentiation. Am. J. Physiol. Endocrinol. Metab. 2010, 298, E1244-E1253. [CrossRef] [PubMed]

180. Rosenwald, M.; Perdikari, A.; Rülicke, T.; Wolfrum, C. Bi-directional interconversion of brite and white adipocytes. Nat. Cell Biol. 2013, 15, 659-667. [CrossRef]

181. Long, J.Z.; Svensson, K.J.; Tsai, L.; Zeng, X.; Roh, H.C.; Kong, X.; Rao, R.R.; Lou, J.; Lokurkar, I.; Baur, W.; et al. A smooth muscle-like origin for beige adipocytes. Cell Metab. 2014, 19, 810-820. [CrossRef] [PubMed]

182. Lee, Y.H.; Petkova, A.P.; Konkar, A.A.; Granneman, J.G. Cellular origins of cold-induced brown adipocytes in adult mice. FASEB J. 2015, 29, 286-299. [CrossRef]

183. Vishvanath, L.; Macpherson, K.A.; Hepler, C.; Wang, Q.A.; Shao, M.; Spurgin, S.B.; Wang, M.Y.; Kusminski, C.M.; Morley, T.S.; Gupta, R.K. Pdgfr $\beta+$ mural preadipocytes contribute to adipocyte hyperplasia induced by high-fat-diet feeding and prolonged cold exposure in adult mice. Cell Metab. 2016, 23, 350-359. [CrossRef] [PubMed]

184. Shao, M.; Wang, Q.A.; Song, A.; Vishvanath, L.; Busbuso, N.C.; Scherer, P.E.; Gupta, R.K. Cellular origins of beige fat cells revisited. Diabetes 2019, 68, 1874-1885. [CrossRef]

185. Jopling, C.; Boue, S.; Belmonte, J.C.I. Dedifferentiation, transdifferentiation and reprogramming: Three routes to regeneration. Nat. Rev. Mol. Cell Biol. 2011, 12, 79-89. [CrossRef] [PubMed]

186. Sebo, Z.L.; Rodeheffer, M.S. Assembling the adipose organ: Adipocyte lineage segregation and adipogenesis in vivo. Development 2019, 146. [CrossRef]

187. Sakamoto, T.; Takahashi, N.; Sawaragi, Y.; Naknukool, S.; Yu, R.; Goto, T.; Kawada, T. Inflammation induced by RAW macrophages suppresses UCP1 mRNA induction via ERK activation in 10T1/2 adipocytes. Am. J. Physiol. Cell Physiol. 2013, 304, C729-C738. [CrossRef] [PubMed]

188. Mund, R.A.; Frishman, W.H. Brown adipose tissue thermogenesis: $\beta 3$-adrenoreceptors as a potential target for the treatment of obesity in humans. Cardiol. Rev. 2013, 21, 265-269. [CrossRef]

189. Than, A.; He, H.L.; Chua, S.H.; Xu, D.; Sun, L.; Leow, M.K.S.; Chen, P. Apelin enhances brown adipogenesis and browning of white adipocytes. J. Biol. Chem. 2015, 290, 14679-14691. [CrossRef] [PubMed]

190. Bartelt, A.; Heeren, J. Adipose tissue browning and metabolic health. Nat. Rev. Endocrinol. 2014, 10, 24-36. [CrossRef] [PubMed] 
191. Nguyen, K.D.; Qiu, Y.; Cui, X.; Goh, Y.P.S.; Mwangi, J.; David, T.; Mukundan, L.; Brombacher, F.; Locksley, R.M.; Chawla, A. Alternatively activated macrophages produce catecholamines to sustain adaptive thermogenesis. Nature 2011, 480, 104-108. [CrossRef]

192. Machida, K.; Okamatsu-Ogura, Y.; Shin, W.; Matsuoka, S.; Tsubota, A.; Kimura, K. Role of macrophages in depot-dependent browning of white adipose tissue. J. Physiol. Sci. 2018, 68, 601-608. [CrossRef] [PubMed]

193. Fischer, A.W.; Schlein, C.; Cannon, B.; Heeren, J.; Nedergaard, J. Intact innervation is essential for diet-induced recruitment of brown adipose tissue. Am. J. Physiol. Endocrinol. Metab. 2019, 316, E487-E503. [CrossRef]

194. Wu, L.; Zhang, L.; Li, B.; Jiang, H.; Duan, Y.; Xie, Z.; Shuai, L.; Li, J.; Li, J. AMP-Activated Protein Kinase (AMPK) regulates energy metabolism through modulating thermogenesis in adipose tissue. Front. Physiol. 2018, 9, 122. [CrossRef]

195. López, M.; Varela, L.; Vázquez, M.J.; Rodríguez-Cuenca, S.; González, C.R.; Velagapudi, V.R.; Morgan, D.A.; Schoenmakers, E.; Agassandian, K.; Lage, R.; et al. Hypothalamic AMPK and fatty acid metabolism mediate thyroid regulation of energy balance. Nat. Med. 2010, 16, 1001-1008. [CrossRef]

196. Watanabe, M.; Houten, S.M.; Mataki, C.; Christoffolete, M.A.; Kim, B.W.; Sato, H.; Messaddeq, N.; Harney, J.W.; Ezaki, O.; Kodama, T.; et al. Bile acids induce energy expenditure by promoting intracellular thyroid hormone activation. Nature 2006, 439, 484-489. [CrossRef]

197. Velazquez-Villegas, L.A.; Perino, A.; Lemos, V.; Zietak, M.; Nomura, M.; Pols, T.W.H.; Schoonjans, K. TGR5 signalling promotes mitochondrial fission and beige remodelling of white adipose tissue. Nat. Commun. 2018, 9, 1-13. [CrossRef]

198. Than, A.; Xu, S.; Li, R.; Leow, M.S.; Sun, L.; Chen, P. Angiotensin type 2 receptor activation promotes browning of white adipose tissue and brown adipogenesis. Signal. Transduct. Target. Ther. 2017, 2, 1-12. [CrossRef]

199. Fisher, F.F.; Kleiner, S.; Douris, N.; Fox, E.C.; Mepani, R.J.; Verdeguer, F.; Wu, J.; Kharitonenkov, A.; Flier, J.S.; Maratos-Flier, E.; et al. FGF21 regulates PGC-1 $\alpha$ and browning of white adipose tissues in adaptive thermogenesis. Genes Dev. 2012, 26, $271-281$. [CrossRef] [PubMed]

200. Morón-Ros, S.; Uriarte, I.; Berasain, C.; Avila, M.A.; Sabater-Masdeu, M.; Moreno-Navarrete, J.M.; Fernández-Real, J.M.; Giralt, M.; Villarroya, F.; Gavaldà-Navarro, A. FGF15/19 is required for adipose tissue plasticity in response to thermogenic adaptations. Mol. Metab. 2021, 43, 101113. [CrossRef] [PubMed]

201. Sun, Y.; Wang, R.; Zhao, S.; Li, W.; Liu, W.; Tang, L.; Wang, Z.; Wang, W.; Liu, R.; Ning, G.; et al. FGF9 inhibits browning program of white adipocytes and associates with human obesity. J. Mol. Endocrinol. 2018, 62, 79-90. [CrossRef] [PubMed]

202. Whittle, A.J.; Carobbio, S.; Martins, L.; Slawik, M.; Hondares, E.; Vázquez, M.J.; Morgan, D.; Csikasz, R.I.; Gallego, R.; Rodriguez-Cuenca, S.; et al. BMP8B increases brown adipose tissue thermogenesis through both central and peripheral actions. Cell 2012, 149, 871-885. [CrossRef]

203. Tseng, Y.H.; Kokkotou, E.; Schulz, T.J.; Huang, T.L.; Winnay, J.N.; Taniguchi, C.M.; Tran, T.T.; Suzuki, R.; Espinoza, D.O.; Yamamoto, Y.; et al. New role of bone morphogenetic protein 7 in brown adipogenesis and energy expenditure. Nature 2008, 454, 1000-1004. [CrossRef]

204. Qian, S.W.; Tang, Y.; Li, X.; Liu, Y.; Zhang, Y.Y.; Huang, H.Y.; Xue, R.D.; Yu, H.Y.; Guo, L.; Gao, H.D.; et al. BMP4-mediated brown fat-like changes in white adipose tissue alter glucose and energy homeostasis. Proc. Natl. Acad. Sci. USA 2013, 110, E798-E807. [CrossRef]

205. Bordicchia, M.; Liu, D.; Amri, E.Z.; Ailhaud, G.; Dessì-Fulgheri, P.; Zhang, C.; Takahashi, N.; Sarzani, R.; Collins, S. Cardiac natriuretic peptides act via p38 MAPK to induce the brown fat thermogenic program in mouse and human adipocytes. J. Clin. Investig. 2012, 122, 1022-1036. [CrossRef]

206. Kimura, H.; Nagoshi, T.; Yoshii, A.; Kashiwagi, Y.; Tanaka, Y.; Ito, K.; Yoshino, T.; Tanaka, T.D.; Yoshimura, M. The thermogenic actions of natriuretic peptide in brown adipocytes: The direct measurement of the intracellular temperature using a fluorescent thermoprobe. Sci. Rep. 2017, 7, 1-10. [CrossRef]

207. Liu, D.; Ceddia, R.P.; Collins, S. Cardiac natriuretic peptides promote adipose 'browning' through mTOR complex-1. Mol. Metab. 2018, 9, 192-198. [CrossRef] [PubMed]

208. Kim, H.; Wrann, C.D.; Jedrychowski, M.; Vidoni, S.; Kitase, Y.; Nagano, K.; Zhou, C.; Chou, J.; Parkman, V.J.A.; Novick, S.J.; et al. Irisin Mediates Effects on Bone and Fat via $\alpha$ V Integrin Receptors. Cell 2018, 175, 1756-1768.e17. [CrossRef] [PubMed]

209. Boström, P.; Wu, J.; Jedrychowski, M.P.; Korde, A.; Ye, L.; Lo, J.C.; Rasbach, K.A.; Boström, E.A.; Choi, J.H.; Long, J.Z.; et al. A PGC1- $\alpha$-dependent myokine that drives brown-fat-like development of white fat and thermogenesis. Nature 2012, 481, 463-468. [CrossRef]

210. Fernández-Verdejo, R.; Marlatt, K.L.; Ravussin, E.; Galgani, J.E. Contribution of brown adipose tissue to human energy metabolism. Mol. Aspects Med. 2019, 68, 82-89. [CrossRef]

211. Bhatt, P.S.; Dhillo, W.S.; Salem, V. Human brown adipose tissue-Function and therapeutic potential in metabolic disease. Curr. Opin. Pharmacol. 2017, 37, 1-9. [CrossRef] [PubMed]

212. Saely, C.H.; Geiger, K.; Drexel, H. Brown versus White Adipose Tissue: A Mini-Review. Gerontology 2012, 58, 15-23. [CrossRef]

213. Davis, R.W.; Davis, R.W. Metabolism and Thermoregulation. In Marine Mammals; Springer: Cham, Switzerland, 2019.

214. Yoneshiro, T.; Matsushita, M.; Nakae, S.; Kameya, T.; Sugie, H.; Tanaka, S.; Saito, M. Brown adipose tissue is involved in the seasonal variation of cold-induced thermogenesis in humans. Am. J. Physiol. Integr. Comp. Physiol. 2016, 310, R999-R1009. [CrossRef] [PubMed] 
215. Wang, Q.; Zhang, M.; Xu, M.; Gu, W.; Xi, Y.; Qi, L.; Li, B.; Wang, W. Brown Adipose Tissue Activation Is Inversely Related to Central Obesity and Metabolic Parameters in Adult Human. PLoS ONE 2015, 10, e0123795. [CrossRef] [PubMed]

216. Van Der Lans, A.A.J.J.; Hoeks, J.; Brans, B.; Vijgen, G.H.E.J.; Visser, M.G.W.; Vosselman, M.J.; Hansen, J.; Jörgensen, J.A.; Wu, J.; Mottaghy, F.M.; et al. Cold acclimation recruits human brown fat and increases nonshivering thermogenesis. J. Clin. Investig. 2013, 123, 3395-3403. [CrossRef]

217. Lowell, B.B.; S-Susulic, V.; Hamann, A.; Lawitts, J.A.; Himms-Hagen, J.; Boyer, B.B.; Kozak, L.P.; Flier, J.S. Development of obesity in transgenic mice after genetic ablation of brown adipose tissue. Nature 1993, 366, 740-742. [CrossRef] [PubMed]

218. Forner, F.; Kumar, C.; Luber, C.A.; Fromme, T.; Klingenspor, M.; Mann, M. Proteome Differences between Brown and White Fat Mitochondria Reveal Specialized Metabolic Functions. Cell Metab. 2009, 10, 324-335. [CrossRef] [PubMed]

219. Keipert, S.; Jastroch, M. Brite/beige fat and UCP1—Is it thermogenesis? Biochim. Biophys. Acta (BBA) Bioenerg. 2014, 1837, 1075-1082. [CrossRef]

220. Klingenspor, M.; Fromme, T.; Hughes, D.A.; Manzke, L.; Polymeropoulos, E.; Riemann, T.; Trzcionka, M.; Hirschberg, V.; Jastroch, M. An ancient look at UCP1. Biochim. Biophys. Acta Bioenerg. 2008, 1777, 637-641. [CrossRef] [PubMed]

221. Chondronikola, M.; Volpi, E.; Børsheim, E.; Porter, C.; Saraf, M.K.; Annamalai, P.; Yfanti, C.; Chao, T.; Wong, D.; Shinoda, K.; et al. Brown Adipose Tissue Activation Is Linked to Distinct Systemic Effects on Lipid Metabolism in Humans. Cell Metab. 2016, 23, 1200-1206. [CrossRef]

222. Bartelt, A.; Bruns, O.T.; Reimer, R.; Hohenberg, H.; Ittrich, H.; Peldschus, K.; Kaul, M.G.; Tromsdorf, U.I.; Weller, H.; Waurisch, C.; et al. Brown adipose tissue activity controls triglyceride clearance. Nat. Med. 2011, 17, 200-206. [CrossRef]

223. Ouellet, V.; Labbé, S.M.; Blondin, D.P.; Phoenix, S.; Guérin, B.; Haman, F.; Turcotte, E.E.; Richard, D.; Carpentier, A.C. Brown adipose tissue oxidative metabolism contributes to energy expenditure during acute cold exposure in humans. J. Clin. Investig. 2012, 122, 545-552. [CrossRef]

224. Enerbäck, S.; Jacobsson, A.; Simpson, E.M.; Guerra, C.; Yamashita, H.; Harper, M.E.; Kozak, L.P. Mice lacking mitochondrial uncoupling protein are cold-sensitive but not obese. Nature 1997, 387, 90-94. [CrossRef]

225. Maurer, S.F.; Fromme, T.; Mocek, S.; Zimmermann, A.; Klingenspor, M. Uncoupling protein 1 and the capacity for nonshivering thermogenesis are components of the glucose homeostatic system. Am. J. Physiol. Endocrinol. Metab. 2020, 318, E198-E215. [CrossRef]

226. Fromme, T.; Hüttinger, K.; Maurer, S.; Li, Y.; Gantert, T.; Fiamoncini, J.; Daniel, H.; Westphal, S.; Klingenspor, M. Bile acid supplementation decreases body mass gain in C57BL/6J but not 129S6/SvEvTac mice without increasing energy expenditure. Sci. Rep. 2019, 9, 1-11. [CrossRef]

227. Liu, X.; Rossmeisl, M.; McClaine, J.; Kozak, L.P. Paradoxical resistance to diet-induced obesity in UCP1-deficient mice. J. Clin. Investig. 2003, 111, 399-407. [CrossRef]

228. Zietak, M.; Kozak, L.P. Bile acids induce uncoupling protein 1-dependent thermogenesis and stimulate energy expenditure at thermoneutrality in mice. Am. J. Physiol. Endocrinol. Metab. 2016, 310, E346-E354. [CrossRef] [PubMed]

229. Ukropec, J.; Anunciado, R.P.; Ravussin, Y.; Hulver, M.W.; Kozak, L.P. UCP1-independent thermogenesis in white adipose tissue of cold-acclimated Ucp1-/- mice. J. Biol. Chem. 2006, 281, 31894-31908. [CrossRef]

230. Meyer, C.W.; Willershäuser, M.; Jastroch, M.; Rourke, B.C.; Fromme, T.; Oelkrug, R.; Heldmaier, G.; Klingenspor, M. Adaptive thermogenesis and thermal conductance in wild-type and UCP1-KO mice. Am. J. Physiol. Regul. Integr. Comp. Physiol. 2010, 299, R1396-R1406. [CrossRef]

231. Hofmann, W.E.; Liu, X.; Bearden, C.M.; Harper, M.E.; Kozak, L.P. Effects of Genetic Background on Thermoregulation and Fatty Acid-induced Uncoupling of Mitochondria in UCP1-deficient Mice. J. Biol. Chem. 2001, 276, 12460-12465. [CrossRef] [PubMed]

232. Keipert, S.; Kutschke, M.; Ost, M.; Schwarzmayr, T.; van Schothorst, E.M.; Lamp, D.; Brachthäuser, L.; Hamp, I.; Mazibuko, S.E.; Hartwig, S.; et al. Long-Term Cold Adaptation Does Not Require FGF21 or UCP1. Cell Metab. 2017, 26, 437-446.e5. [CrossRef] [PubMed]

233. Antonacci, M.A.; McHugh, C.; Kelley, M.; McCallister, A.; Degan, S.; Branca, R.T. Direct detection of brown adipose tissue thermogenesis in UCP1 - / - mice by hyperpolarized 129Xe MR thermometry. Sci. Rep. 2019, 9, 1-12. [CrossRef]

234. Long, J.Z.; Svensson, K.J.; Bateman, L.A.; Lin, H.; Kamenecka, T.; Lokurkar, I.A.; Lou, J.; Rao, R.R.; Chang, M.R.R.; Jedrychowski, M.P.; et al. The Secreted Enzyme PM20D1 Regulates Lipidated Amino Acid Uncouplers of Mitochondria. Cell 2016, 166, 424-435. [CrossRef] [PubMed]

235. Anunciado-Koza, R.P.; Zhang, J.; Ukropec, J.; Bajpeyi, S.; Koza, R.A.; Rogers, R.C.; Cefalu, W.T.; Mynatt, R.L.; Kozak, L.P. Inactivation of the mitochondrial carrier SLC25A25 (ATP-Mg2+/Pi transporter) reduces physical endurance and metabolic efficiency in mice. J. Biol. Chem. 2011, 286, 11659-11671. [CrossRef]

236. Bertholet, A.M.; Chouchani, E.T.; Kazak, L.; Angelin, A.; Fedorenko, A.; Long, J.Z.; Vidoni, S.; Garrity, R.; Cho, J.; Terada, N.; et al. $\mathrm{H}+$ transport is an integral function of the mitochondrial ADP/ATP carrier. Nature 2019, 571, 515-520. [CrossRef] [PubMed]

237. Kazak, L.; Chouchani, E.T.; Jedrychowski, M.P.; Erickson, B.K.; Shinoda, K.; Cohen, P.; Vetrivelan, R.; Lu, G.Z.; Laznik-Bogoslavski, D.; Hasenfuss, S.C.; et al. A Creatine-Driven Substrate Cycle Enhances Energy Expenditure and Thermogenesis in Beige Fat. Cell 2015, 163, 643-655. [CrossRef]

238. Perna, M.K.; Kokenge, A.N.; Miles, K.N.; Udobi, K.C.; Clark, J.F.; Pyne-Geithman, G.J.; Khuchua, Z.; Skelton, M.R. Creatine transporter deficiency leads to increased whole body and cellular metabolism. Amino Acids 2016, 48, 2057-2065. [CrossRef] [PubMed] 
239. Kazak, L.; Chouchani, E.T.; Lu, G.Z.; Jedrychowski, M.P.; Bare, C.J.; Mina, A.I.; Kumari, M.; Zhang, S.; Vuckovic, I.; Laznik-Bogoslavski, D.; et al. Genetic Depletion of Adipocyte Creatine Metabolism Inhibits Diet-Induced Thermogenesis and Drives Obesity. Cell Metab. 2017, 26, 660-671.e3. [CrossRef]

240. Kazak, L.; Rahbani, J.F.; Samborska, B.; Lu, G.Z.; Jedrychowski, M.P.; Lajoie, M.; Zhang, S.; Ramsay, L.A.; Dou, F.Y.; Tenen, D.; et al. Ablation of adipocyte creatine transport impairs thermogenesis and causes diet-induced obesity. Nat. Metab. 2019, 1, 360-370. [CrossRef]

241. Mottillo, E.P.; Balasubramanian, P.; Lee, Y.H.; Weng, C.; Kershaw, E.E.; Granneman, J.G. Coupling of lipolysis and de novo lipogenesis in brown, beige, and white adipose tissues during chronic $\beta 3$-adrenergic receptor activation. J. Lipid Res. 2014, 55, 2276-2286. [CrossRef]

242. Schweizer, S.; Oeckl, J.; Klingenspor, M.; Fromme, T. Substrate fluxes in brown adipocytes upon adrenergic stimulation and uncoupling protein 1 ablation. Life Sci. Alliance 2018, 1. [CrossRef]

243. Campbell, K.L.; Dicke, A.A. Sarcolipin makes heat, but is it adaptive thermogenesis? Front. Physiol. 2018, 9, 714. [CrossRef]

244. Ikeda, K.; Kang, Q.; Yoneshiro, T.; Camporez, J.P.; Maki, H.; Homma, M.; Shinoda, K.; Chen, Y.; Lu, X.; Maretich, P.; et al. UCP1-independent signaling involving SERCA2bmediated calcium cycling regulates beige fat thermogenesis and systemic glucose homeostasis. Nat. Med. 2017, 23, 1454-1465. [CrossRef]

245. Brand, M.D.; Pakay, J.L.; Ocloo, A.; Kokoszka, J.; Wallace, D.C.; Brookes, P.S.; Cornwall, E.J. The basal proton conductance of mitochondria depends on adenine nucleotide translocase content. Biochem. J. 2005, 392, 353-362. [CrossRef]

246. Lee, Y.S.; Kim, J.W.; Osborne, O.; Oh, D.Y.; Sasik, R.; Schenk, S.; Chen, A.; Chung, H.; Murphy, A.; Watkins, S.M.; et al. Increased adipocyte $\mathrm{O} 2$ consumption triggers HIF-1 $\alpha$, causing inflammation and insulin resistance in obesity. Cell 2014, 157, 1339-1352. [CrossRef]

247. Fischer, A.W.; Jaeckstein, M.Y.; Gottschling, K.; Heine, M.; Sass, F.; Mangels, N.; Schlein, C.; Worthmann, A.; Bruns, O.T.; Yuan, Y.; et al. Lysosomal lipoprotein processing in endothelial cells stimulates adipose tissue thermogenic adaptation. Cell Metab. 2021, 33, 547-564. [CrossRef]

248. Verkerke, A.R.P.; Kajimura, S. Oil does more than light the lamp: The multifaceted role of lipids in thermogenic fat. Dev. Cell. 2021, 56, 1408-1416. [CrossRef]

249. Heine, M.; Fischer, A.W.; Schlein, C.; Jung, C.; Straub, L.G.; Gottschling, K.; Mangels, N.; Yuan, Y.; Nilsson, S.K.; Liebscher, G.; et al. Lipolysis Triggers a Systemic Insulin Response Essential for Efficient Energy Replenishment of Activated Brown Adipose Tissue in Mice. Cell Metab. 2018, 28, 644-655.e4. [CrossRef] [PubMed]

250. Sanchez-Gurmaches, J.; Tang, Y.; Jespersen, N.Z.; Wallace, M.; Martinez Calejman, C.; Gujja, S.; Li, H.; Edwards, Y.J.K.; Wolfrum, C.; Metallo, C.M.; et al. Brown Fat AKT2 Is a Cold-Induced Kinase that Stimulates ChREBP-Mediated De Novo Lipogenesis to Optimize Fuel Storage and Thermogenesis. Cell Metab. 2018, 27, 195-209.e6. [CrossRef] [PubMed]

251. Inokuma, K.I.; Ogura-Okamatsu, Y.; Toda, C.; Kimura, K.; Yamashita, H.; Saito, M. Uncoupling protein 1 is necessary for norepinephrine-induced glucose utilization in brown adipose tissue. Diabetes 2005, 54, 1385-1391. [CrossRef] [PubMed]

252. Wu, J.; Cohen, P.; Spiegelman, B.M. Adaptive thermogenesis in adipocytes: Is beige the new brown? Genes Dev. 2013, 27, 234-250. [CrossRef] [PubMed]

253. Hankir, M.K.; Klingenspor, M. Brown adipocyte glucose metabolism: A heated subject. EMBO Rep. 2018, 19, e46404. [CrossRef] [PubMed]

254. Villarroya, J.; Cereijo, R.; Giralt, M.; Villarroya, F. Secretory Proteome of Brown Adipocytes in Response to cAMP-Mediated Thermogenic Activation. Front. Physiol. 2019, 10, 67. [CrossRef]

255. Ali Khan, A.; Hansson, J.; Weber, P.; Foehr, S.; Krijgsveld, J.; Herzig, S.; Scheideler, M. Comparative secretome analyses of primary murine white and brown adipocytes reveal novel adipokines. Mol. Cell. Proteomics 2018, 17, 2358-2370. [CrossRef]

256. Scheja, L.; Heeren, J. The endocrine function of adipose tissues in health and cardiometabolic disease. Nat. Rev. Endocrinol. 2019, 15, 507-524. [CrossRef]

257. Villarroya, F.; Gavaldà-Navarro, A.; Peyrou, M.; Villarroya, J.; Giralt, M. The Lives and Times of Brown Adipokines. Trends Endocrinol. Metab. 2017, 28, 855-867. [CrossRef]

258. Sponton, C.H.; Kajimura, S. Multifaceted roles of beige fat in energy homeostasis beyond UCP1. Endocrinology 2018, 159, 2545-2553. [CrossRef]

259. Kulterer, O.C.; Niederstaetter, L.; Herz, C.T.; Haug, A.R.; Bileck, A.; Pils, D.; Kautzky-Willer, A.; Gerner, C.; Kiefer, F.W. The Presence of Active Brown Adipose Tissue Determines Cold-Induced Energy Expenditure and Oxylipin Profiles in Humans. J. Clin. Endocrinol. Metab. 2020, 105, 2203-2216. [CrossRef]

260. Lynes, M.D.; Leiria, L.O.; Lundh, M.; Bartelt, A.; Shamsi, F.; Huang, T.L.; Takahashi, H.; Hirshman, M.F.; Schlein, C.; Lee, A.; et al. The cold-induced lipokine 12,13-diHOME promotes fatty acid transport into brown adipose tissue. Nat. Med. 2017, 23, 631-637. [CrossRef]

261. Vasan, S.K.; Noordam, R.; Gowri, M.S.; Neville, M.J.; Karpe, F.; Christodoulides, C. The proposed systemic thermogenic metabolites succinate and 12,13-diHOME are inversely associated with adiposity and related metabolic traits: Evidence from a large human cross-sectional study. Diabetologia 2019, 62, 2079-2087. [CrossRef]

262. Stanford, K.I.; Lynes, M.D.; Takahashi, H.; Baer, L.A.; Arts, P.J.; May, F.J.; Lehnig, A.C.; Middelbeek, R.J.W.; Richard, J.J.; So, K.; et al. 12,13-diHOME: An Exercise-Induced Lipokine that Increases Skeletal Muscle Fatty Acid Uptake. Cell Metab. 2018, 27, 1111-1120.e3. [CrossRef] 
263. Pinckard, K.M.; Shettigar, V.K.; Wright, K.R.; Abay, E.; Baer, L.A.; Vidal, P.; Dewal, R.S.; Das, D.; Duarte-Sanmiguel, S.; Hernández-Saavedra, D.; et al. A Novel Endocrine Role for the BAT-Released Lipokine 12,13-diHOME to Mediate Cardiac Function. Circulation 2021, 143, 145-159. [CrossRef]

264. Leiria, L.O.; Wang, C.H.; Lynes, M.D.; Yang, K.; Shamsi, F.; Sato, M.; Sugimoto, S.; Chen, E.Y.; Bussberg, V.; Narain, N.R.; et al. 12-Lipoxygenase Regulates Cold Adaptation and Glucose Metabolism by Producing the Omega-3 Lipid 12-HEPE from Brown Fat. Cell Metab. 2019, 30, 768-783.e7. [CrossRef]

265. Vegiopoulos, A.; Müller-Decker, K.; Strzoda, D.; Schmitt, I.; Chichelnitskiy, E.; Ostertag, A.; Diaz, M.B.; Rozman, J.; De Angelis, M.H.; Nüsing, R.M.; et al. Cyclooxygenase-2 controls energy homeostasis in mice by de novo recruitment of brown adipocytes. Science 2010, 328, 1158-1161. [CrossRef]

266. Virtue, S.; Feldmann, H.; Christian, M.; Tan, C.Y.; Masoodi, M.; Dale, M.; Lelliott, C.; Burling, K.; Campbell, M.; Eguchi, N.; et al. A new role for lipocalin prostaglandin D synthase in the regulation of brown adipose tissue substrate utilization. Diabetes 2012, 61, 3139-3147. [CrossRef]

267. García-Alonso, V.; Clária, J. Prostaglandin E 2 signals white-to-brown adipogenic differentiation. Adipocyte 2014, 3, 290-296. [CrossRef]

268. García-Alonso, V.; Titos, E.; Alcaraz-Quiles, J.; Rius, B.; Lopategi, A.; López-Vicario, C.; Jakobsson, P.J.; Delgado, S.; Lozano, J.; Clària, J. Prostaglandin E2 exerts multiple regulatory actions on human obese adipose tissue remodeling, inflammation, adaptive thermogenesis and lipolysis. PLoS ONE 2016, 11, e0153751. [CrossRef]

269. Mahdaviani, K.; Chess, D.; Wu, Y.; Shirihai, O.; Aprahamian, T.R. Autocrine effect of vascular endothelial growth factor-A is essential for mitochondrial function in brown adipocytes. Metabolism. 2016, 65, 26-35. [CrossRef]

270. Sun, K.; Kusminski, C.M.; Luby-Phelps, K.; Spurgin, S.B.; An, Y.A.; Wang, Q.A.; Holland, W.L.; Scherer, P.E. Brown adipose tissue derived VEGF-A modulates cold tolerance and energy expenditure. Mol. Metab. 2014, 3, 474-483. [CrossRef]

271. Shimizu, I.; Aprahamian, T.; Kikuchi, R.; Shimizu, A.; Papanicolaou, K.N.; MacLauchlan, S.; Maruyama, S.; Walsh, K. Vascular rarefaction mediates whitening of brown fat in obesity. J. Clin. Investig. 2014, 124, 2099-2112. [CrossRef]

272. Park, J.; Kim, M.; Sun, K.; An, Y.A.; Gu, X.; Scherer, P.E. VEGF-A—Expressing adipose tissue shows rapid beiging and enhanced survival after transplantation and confers IL-4-independent metabolic improvements. Diabetes 2017, 66, 1479-1490. [CrossRef]

273. Nisoli, E.; Tonello, C.; Briscini, L.; Carruba, M.O. Inducible Nitric Oxide Synthase in Rat Brown Adipocytes: Implications for Blood Flow to Brown Adipose Tissue. Endocrinology 1997, 138, 676-682. [CrossRef]

274. Roberts, L.D.; Ashmore, T.; Kotwica, A.O.; Murfitt, S.A.; Fernandez, B.O.; Feelisch, M.; Murray, A.J.; Griffin, J.L. Inorganic nitrate promotes the browning of white adipose tissue through the nitrate-nitrite-nitric oxide pathway. Diabetes 2015, 64, 471-484. [CrossRef] [PubMed]

275. Friederich-Persson, M.; Nguyen Dinh Cat, A.; Persson, P.; Montezano, A.C.; Touyz, R.M. Brown Adipose Tissue Regulates Small Artery Function Through NADPH Oxidase 4-Derived Hydrogen Peroxide and Redox-Sensitive Protein Kinase G-1. Arterioscler. Thromb. Vasc. Biol. 2017, 37, 455-465. [CrossRef]

276. Wang, G.X.; Zhao, X.Y.; Meng, Z.X.; Kern, M.; Dietrich, A.; Chen, Z.; Cozacov, Z.; Zhou, D.; Okunade, A.L.; Su, X.; et al. The brown fat-enriched secreted factor Nrg4 preserves metabolic homeostasis through attenuation of hepatic lipogenesis. Nat. Med. 2014, 20, 1436-1443. [CrossRef] [PubMed]

277. Rosell, M.; Kaforou, M.; Frontini, A.; Okolo, A.; Chan, Y.W.; Nikolopoulou, E.; Millership, S.; Fenech, M.E.; MacIntyre, D.; Turner, J.O.; et al. Brown and white adipose tissues: Intrinsic differences in gene expression and response to cold exposure in mice. Am. J. Physiol. Endocrinol. Metab. 2014, 306, E945. [CrossRef] [PubMed]

278. Comas, F.; Martínez, C.; Sabater, M.; Ortega, F.; Latorre, J.; Díaz-Sáez, F.; Aragonés, J.; Camps, M.; Gumà, A.; Ricart, W.; et al. Neuregulin 4 Is a Novel Marker of Beige Adipocyte Precursor Cells in Human Adipose Tissue. Front. Physiol. 2019, 10, 39. [CrossRef]

279. Chen, Z.; Wang, G.X.; Ma, S.L.; Jung, D.Y.; Ha, H.; Altamimi, T.; Zhao, X.Y.; Guo, L.; Zhang, P.; Hu, C.R.; et al. Nrg4 promotes fuel oxidation and a healthy adipokine profile to ameliorate diet-induced metabolic disorders. Mol. Metab. 2017, 6, 863-872. [CrossRef] [PubMed]

280. Ruan, C.C.; Kong, L.R.; Chen, X.H.; Ma, Y.; Pan, X.X.; Zhang, Z.B.; Gao, P.J. A2A Receptor Activation Attenuates Hypertensive Cardiac Remodeling via Promoting Brown Adipose Tissue-Derived FGF21. Cell Metab. 2018, 28, 476-489.e5. [CrossRef]

281. Hondares, E.; Iglesias, R.; Giralt, A.; Gonzalez, F.J.; Giralt, M.; Mampel, T.; Villarroya, F. Thermogenic activation induces FGF21 expression and release in brown adipose tissue. J. Biol. Chem. 2011, 286, 12983-12990. [CrossRef] [PubMed]

282. Lee, P.; Linderman, J.D.; Smith, S.; Brychta, R.J.; Wang, J.; Idelson, C.; Perron, R.M.; Werner, C.D.; Phan, G.Q.; Kammula, U.S.; et al. Irisin and FGF21 are cold-induced endocrine activators of brown fat function in humans. Cell Metab. 2014, 19, 302-309. [CrossRef]

283. Ramos, D.C.; Mehta, R.; Aguilar-Salinas, C.A. Fibroblast Growth Factor 21 and Browning of White Adipose Tissue. Front. Physiol. 2019, 10, 37. [CrossRef] [PubMed]

284. Hondares, E.; Gallego-Escuredo, J.M.; Flachs, P.; Frontini, A.; Cereijo, R.; Goday, A.; Perugini, J.; Kopecky, P.; Giralt, M.; Cinti, S.; et al. Fibroblast growth factor-21 is expressed in neonatal and pheochromocytoma-induced adult human brown adipose tissue. Metabolism 2014, 63, 312-317. [CrossRef]

285. Giralt, M.; Gavaldà-Navarro, A.; Villarroya, F. Fibroblast growth factor-21, energy balance and obesity. Mol. Cell. Endocrinol. 2015, 418, 66-73. [CrossRef] 
286. Stanford, K.I.; Middelbeek, R.J.W.; Townsend, K.L.; An, D.; Nygaard, E.B.; Hitchcox, K.M.; Markan, K.R.; Nakano, K.; Hirshman, M.F.; Tseng, Y.H.; et al. Brown adipose tissue regulates glucose homeostasis and insulin sensitivity. J. Clin. Investig. 2013, 123, 215-223. [CrossRef] [PubMed]

287. Lee, P.; Brychta, R.J.; Linderman, J.; Smith, S.; Chen, K.Y.; Celi, F.S. Mild Cold Exposure Modulates Fibroblast Growth Factor 21 (FGF21) Diurnal Rhythm in Humans: Relationship between FGF21 Levels, Lipolysis, and Cold-Induced Thermogenesis. J. Clin. Endocrinol. Metab. 2013, 98, E98-E102. [CrossRef] [PubMed]

288. Klepac, K.; Kilić, A.; Gnad, T.; Brown, L.M.; Herrmann, B.; Wilderman, A.; Balkow, A.; Glöde, A.; Simon, K.; Lidell, M.E.; et al. The G q signalling pathway inhibits brown and beige adipose tissue. Nat. Commun. 2016, 7, 1-10. [CrossRef]

289. Janssen, L.G.M.; Jauhiainen, M.; Olkkonen, V.M.; Haridas, P.A.N.; Nahon, K.J.; Rensen, P.C.N.; Boon, M.R. Short-Term Cooling Increases Plasma ANGPTL3 and ANGPTL8 in Young Healthy Lean Men but Not in Middle-Aged Men with Overweight and Prediabetes. J. Clin. Med. 2019, 8, 1214. [CrossRef] [PubMed]

290. Fu, Z.; Yao, F.; Abou-Samra, A.B.; Zhang, R. Lipasin, thermoregulated in brown fat, is a novel but atypical member of the angiopoietin-like protein family. Biochem. Biophys. Res. Commun. 2013, 430, 1126-1131. [CrossRef]

291. Martinez-Perez, B.; Ejarque, M.; Gutierrez, C.; Nuñez-Roa, C.; Roche, K.; Vila-Bedmar, R.; Ballesteros, M.; Redondo-Angulo, I.; Planavila, A.; Villarroya, F; et al. Angiopoietin-like protein 8 (ANGPTL8) in pregnancy: A brown adipose tissue-derived endocrine factor with a potential role in fetal growth. Transl. Res. 2016, 178, 1-12. [CrossRef]

292. Singh, A.K.; Aryal, B.; Chaube, B.; Rotllan, N.; Varela, L.; Horvath, T.L.; Suárez, Y.; Fernández-Hernando, C. Brown adipose tissue derived ANGPTL4 controls glucose and lipid metabolism and regulates thermogenesis. Mol. Metab. 2018, 11, 59-69. [CrossRef] [PubMed]

293. Dijk, W.; Heine, M.; Vergnes, L.; Boon, M.R.; Schaart, G.; Hesselink, M.K.C.; Reue, K.; van Marken Lichtenbelt, W.D.; Olivecrona, G.; Rensen, P.C.N.; et al. ANGPTL4 mediates shuttling of lipid fuel to brown adipose tissue during sustained cold exposure. eLife 2015, 4, e08428. [CrossRef] [PubMed]

294. Aryal, B.; Singh, A.K.; Zhang, X.; Varela, L.; Rotllan, N.; Goedeke, L.; Chaube, B.; Camporez, J.P.; Vatner, D.F.; Horvath, T.L.; et al. Absence of ANGPTL4 in adipose tissue improves glucose tolerance and attenuates atherogenesis. JCI Insight 2018, 3. [CrossRef]

295. Steculorum, S.M.; Ruud, J.; Karakasilioti, I.; Backes, H.; Engström Ruud, L.; Timper, K.; Hess, M.E.; Tsaousidou, E.; Mauer, J.; Vogt, M.C.; et al. AgRP Neurons Control Systemic Insulin Sensitivity via Myostatin Expression in Brown Adipose Tissue. Cell 2016, 165, 125-138. [CrossRef]

296. Fournier, B.; Murray, B.; Gutzwiller, S.; Marcaletti, S.; Marcellin, D.; Bergling, S.; Brachat, S.; Persohn, E.; Pierrel, E.; Bombard, F; et al. Blockade of the Activin Receptor IIB Activates Functional Brown Adipogenesis and Thermogenesis by Inducing Mitochondrial Oxidative Metabolism. Mol. Cell. Biol. 2012, 32, 2871-2879. [CrossRef] [PubMed]

297. Kong, X.; Yao, T.; Zhou, P.; Kazak, L.; Tenen, D.; Lyubetskaya, A.; Dawes, B.A.; Tsai, L.; Kahn, B.B.; Spiegelman, B.M.; et al. Brown Adipose Tissue Controls Skeletal Muscle Function via the Secretion of Myostatin. Cell Metab. 2018, 28, 631-643.e3. [CrossRef] [PubMed]

298. Cioffi, F.; Gentile, A.; Silvestri, E.; Goglia, F.; Lombardi, A. Effect of Iodothyronines on Thermogenesis: Focus on Brown Adipose Tissue. Front. Endocrinol. 2018, 9, 254. [CrossRef] [PubMed]

299. Yau, W.W.; Singh, B.K.; Lesmana, R.; Zhou, J.; Sinha, R.A.; Wong, K.A.; Wu, Y.; Bay, B.H.; Sugii, S.; Sun, L.; et al. Thyroid hormone (T3) stimulates brown adipose tissue activation via mitochondrial biogenesis and MTOR-mediated mitophagy. Autophagy 2019, 15, 131-150. [CrossRef] [PubMed]

300. De Jesus, L.A.; Carvalho, S.D.; Ribeiro, M.O.; Schneider, M.; Kim, S.-W.; Harney, J.W.; Larsen, P.R.; Bianco, A.C. The type 2 iodothyronine deiodinase is essential for adaptive thermogenesis in brown adipose tissue. J. Clin. Investig. 2001, 108, 1379-1385. [CrossRef]

301. Bianco, A.C.; McAninch, E.A. The role of thyroid hormone and brown adipose tissue in energy homoeostasis. Lancet Diabetes Endocrinol. 2013, 1, 250-258. [CrossRef]

302. Gnad, T.; Scheibler, S.; Von Kugelgen, I.; Scheele, C.; Kilic, A.; Glode, A.; Hoffmann, L.S.; Reverte-Salisa, L.; Horn, P.; Mutlu, S.; et al. Adenosine activates brown adipose tissue and recruits beige adipocytes via A2A receptors. Nature 2014, 516, 395-399. [CrossRef]

303. Deshmukh, A.S.; Peijs, L.; Beaudry, J.L.; Jespersen, N.Z.; Nielsen, C.H.; Ma, T.; Brunner, A.D.; Larsen, T.J.; Bayarri-Olmos, R.; Prabhakar, B.S.; et al. Proteomics-Based Comparative Mapping of the Secretomes of Human Brown and White Adipocytes Reveals EPDR1 as a Novel Batokine. Cell Metab. 2019, 30, 963-975.e7. [CrossRef]

304. Fang, D.; Shi, X.; Lu, T.; Ruan, H.; Gao, Y. The glycoprotein follistatin-like 1 promotes brown adipose thermogenesis. Metabolism 2019, 98, 16-26. [CrossRef] [PubMed]

305. Krott, L.M.; Piscitelli, F.; Heine, M.; Borrino, S.; Scheja, L.; Silvestri, C.; Heeren, J.; Di Marzo, V. Endocannabinoid regulation in white and brown adipose tissue following thermogenic activation. J. Lipid Res. 2016, 57, 464-473. [CrossRef]

306. Boon, M.R.; Kooijman, S.; Van Dam, A.D.; Pelgrom, L.R.; Berbée, J.F.P.; Visseren, C.A.R.; Van Aggele, R.C.; Van Den Hoek, A.M.; Sips, H.C.M.; Lombès, M.; et al. Peripheral cannabinoid 1 receptor blockade activates brown adipose tissue and diminishes dyslipidemia and obesity. FASEB J. 2014, 28, 5361-5375. [CrossRef]

307. Jung, K.M.; Lin, L.; Piomelli, D. The endocannabinoid system in the adipose organ. Rev. Endocr. Metab. Disord. 2021, 1-10. [CrossRef] 
308. Whittle, A.J.; Jiang, M.; Peirce, V.; Relat, J.; Virtue, S.; Ebinuma, H.; Fukamachi, I.; Yamaguchi, T.; Takahashi, M.; Murano, T.; et al. Soluble LR11/SorLA represses thermogenesis in adipose tissue and correlates with BMI in humans. Nat. Commun. 2015, 6, 1-12. [CrossRef]

309. Svensson, K.J.; Long, J.Z.; Jedrychowski, M.P.; Cohen, P.; Lo, J.C.; Serag, S.; Kir, S.; Shinoda, K.; Tartaglia, J.A.; Rao, R.R.; et al. A secreted slit2 fragment regulates adipose tissue thermogenesis and metabolic function. Cell Metab. 2016, 23, 454-466. [CrossRef] [PubMed]

310. Kang, Y.E.; Choung, S.; Lee, J.H.; Kim, H.J.; Ku, B.J. The role of circulating slit2, the one of the newly batokines, in human diabetes mellitus. Endocrinol. Metab. 2017, 32, 383-388. [CrossRef] [PubMed]

311. Villarroya, J.; Cereijo, R.; Gavaldà-Navarro, A.; Peyrou, M.; Giralt, M.; Villarroya, F. New insights into the secretory functions of brown adipose tissue. J. Endocrinol. 2019, 243, R19-R27. [CrossRef]

312. Pellegrinelli, V.; Peirce, V.J.; Howard, L.; Virtue, S.; Türei, D.; Senzacqua, M.; Frontini, A.; Dalley, J.W.; Horton, A.R.; Bidault, G.; et al. Adipocyte-secreted BMP8b mediates adrenergic-induced remodeling of the neuro-vascular network in adipose tissue. Nat. Commun. 2018, 9, 1-18. [CrossRef]

313. Rahman, S.; Lu, Y.; Czernik, P.J.; Rosen, C.J.; Enerback, S.; Lecka-Czernik, B. Inducible brown adipose tissue, or beige fat, is anabolic for the skeleton. Endocrinology 2013, 154, 2687-2701. [CrossRef]

314. Xi, G.; Wai, C.; DeMambro, V.; Rosen, C.J.; Clemmons, D.R. IGFBP-2 directly stimulates osteoblast differentiation. J. Bone Miner. Res. 2014, 29, 2427-2438. [CrossRef] [PubMed]

315. Lidell, M.E.; Enerbäck, S. Brown adipose tissue and bone. Int. J. Obes. Suppl. 2015, 5, S23-S27. [CrossRef] [PubMed]

316. Bredella, M.A.; Fazeli, P.K.; Lecka-Czernik, B.; Rosen, C.J.; Klibanski, A. IGFBP-2 is a negative predictor of cold-induced brown fat and bone mineral density in young non-obese women. Bone 2013, 53, 336-339. [CrossRef]

317. DeMambro, V.E.; Le, P.T.; Guntur, A.R.; Maridas, D.E.; Canalis, E.; Nagano, K.; Baron, R.; Clemmons, D.R.; Rosen, C.J. Igfbp2 deletion in ovariectomized mice enhances energy expenditure but accelerates bone loss. Endocrinology 2015, 156, 4129-4140. [CrossRef]

318. Whitehead, A.; Krause, F.N.; Moran, A.; MacCannell, A.D.V.; Scragg, J.L.; McNally, B.D.; Boateng, E.; Murfitt, S.A.; Virtue, S.; Wright, J.; et al. Brown and beige adipose tissue regulate systemic metabolism through a metabolite interorgan signaling axis. Nat. Commun. 2021, 12, 1905. [CrossRef]

319. Kristóf, E.; Klusóczki, Á.; Veress, R.; Shaw, A.; Combi, Z.S.; Varga, K.; Győry, F.; Balajthy, Z.; Bai, P.; Bacso, Z.; et al. Interleukin-6 released from differentiating human beige adipocytes improves browning. Exp. Cell Res. 2019, 377, 47-55. [CrossRef]

320. Egecioglu, E.; Anesten, F.; Schéle, E.; Palsdottir, V. Interleukin-6 is important for regulation of core body temperature during long-term cold exposure in mice. Biomed. Rep. 2018, 9, 206-212. [CrossRef]

321. Burýšek, L.; Houštěk, J. $\beta$-Adrenergic stimulation of interleukin- $1 \alpha$ and interleukin- 6 expression in mouse brown adipocytes. FEBS Lett. 1997, 411, 83-86. [CrossRef]

322. Reilly, S.M.; Ahmadian, M.; Zamarron, B.F.; Chang, L.; Uhm, M.; Poirier, B.; Peng, X.; Krause, D.M.; Korytnaya, E.; Neidert, A.; et al. A subcutaneous adipose tissue-liver signalling axis controls hepatic gluconeogenesis. Nat. Commun. 2015, 6, 1-12. [CrossRef] [PubMed]

323. Cereijo, R.; Gavaldà-Navarro, A.; Cairó, M.; Quesada-López, T.; Villarroya, J.; Morón-Ros, S.; Sánchez-Infantes, D.; Peyrou, M.; Iglesias, R.; Mampel, T.; et al. CXCL14, a Brown Adipokine that Mediates Brown-Fat-to-Macrophage Communication in Thermogenic Adaptation. Cell Metab. 2018, 28, 750-763.e6. [CrossRef] [PubMed]

324. Hui, X.; Gu, P.; Zhang, J.; Nie, T.; Pan, Y.; Wu, D.; Feng, T.; Zhong, C.; Wang, Y.; Lam, K.S.L.; et al. Adiponectin Enhances ColdInduced Browning of Subcutaneous Adipose Tissue via Promoting M2 Macrophage Proliferation. Cell Metab 2015, 22, 279-290. [CrossRef] [PubMed]

325. Rao, R.R.; Long, J.Z.; White, J.P.; Svensson, K.J.; Lou, J.; Lokurkar, I.; Jedrychowski, M.P.; Ruas, J.L.; Wrann, C.D.; Lo, J.C.; et al. Meteorin-like is a hormone that regulates immune-adipose interactions to increase beige fat thermogenesis. Cell 2014, 157, 1279-1291. [CrossRef]

326. Campderrós, L.; Moure, R.; Cairó, M.; Gavaldà-Navarro, A.; Quesada-López, T.; Cereijo, R.; Giralt, M.; Villarroya, J.; Villarroya, F. Brown Adipocytes Secrete GDF15 in Response to Thermogenic Activation. Obesity 2019, 27, 1606-1616. [CrossRef] [PubMed]

327. Oka, M.; Kobayashi, N.; Matsumura, K.; Nishio, M.; Nakano, K.; Okamura, T.; Okochi, H.; Minamisawa, T.; Shiba, K.; Saeki, K. New Role for Growth/Differentiation Factor 15 in the Survival of Transplanted Brown Adipose Tissues in Cooperation with Interleukin-6. Cells 2020, 9, 1365. [CrossRef] [PubMed]

328. Gunawardana, S.C.; Piston, D.W. Insulin-independent reversal of type 1 diabetes in nonobese diabetic mice with brown adipose tissue transplant. Am. J. Physiol. Endocrinol. Metab. 2015, 308, E1043-E1055. [CrossRef]

329. Duchamp, C.; Burton, K.A.; Géloën, A.; Dauncey, M.J. Transient upregulation of IGF-I gene expression in brown adipose tissue of cold-exposed rats. Am. J. Physiol. Endocrinol. Metab. 1997, 272, E453-E460. [CrossRef]

330. Chang, H.R.; Kim, H.J.; Xu, X.; Ferrante, A.W. Macrophage and adipocyte IGF1 maintain adipose tissue homeostasis during metabolic stresses. Obesity 2016, 24, 172-183. [CrossRef]

331. Lorenzo, M.; Valverde, A.M.; Teruel, T.; Benito, M. IGF-I is a mitogen involved in differentiation-related gene expression in fetal rat brown adipocytes. J. Cell Biol. 1993, 123, 1567-1575. [CrossRef] 
332. Hansen, I.R.; Jansson, K.M.; Cannon, B.; Nedergaard, J. Contrasting effects of cold acclimation versus obesogenic diets on chemerin gene expression in brown and brite adipose tissues. Biochim. Biophys. Acta Mol. Cell Biol. Lipids 2014, 1841, 1691-1699. [CrossRef]

333. Rourke, J.L.; Muruganandan, S.; Dranse, H.J.; McMullen, N.M.; Sinal, C.J. Gpr1 is an active chemerin receptor influencing glucose homeostasis in obese mice. J. Endocrinol. 2014, 222, 201-215. [CrossRef]

334. Thomou, T.; Mori, M.A.; Dreyfuss, J.M.; Konishi, M.; Sakaguchi, M.; Wolfrum, C.; Rao, T.N.; Winnay, J.N.; Garcia-Martin, R.; Grinspoon, S.K.; et al. Adipose-derived circulating miRNAs regulate gene expression in other tissues. Nature 2017, 542, 450-455. [CrossRef]

335. Chen, Y.; Buyel, J.J.; Hanssen, M.J.W.; Siegel, F.; Pan, R.; Naumann, J.; Schell, M.; Van Der Lans, A.; Schlein, C.; Froehlich, H.; et al Exosomal microRNA miR-92a concentration in serum reflects human brown fat activity. Nat. Commun. 2016, 7, 1-9. [CrossRef]

336. Nisoli, E.; Tonello, C.; Benarese, M.; Liberini, P.; Carruba, M.O. Expression of nerve growth factor in brown adipose tissue: Implications for thermogenesis and obesity. Endocrinology 1996, 137, 495-503. [CrossRef] [PubMed]

337. Plucińska, K.; Jespersen, N.Z.; Brown, E.L.; Petersen, P.S.; Rupar, K.; Nielsen, S.; Scheele, C.; Emanuelli, B. Calsyntenin $3 \beta$ Is Dynamically Regulated by Temperature in Murine Brown Adipose and Marks Human Multilocular Fat. Front. Endocrinol. 2020, 11, 767. [CrossRef]

338. Zeng, X.; Ye, M.; Resch, J.M.; Jedrychowski, M.P.; Hu, B.; Lowell, B.B.; Ginty, D.D.; Spiegelman, B.M. Innervation of thermogenic adipose tissue via a calsyntenin $3 \beta-S 100 b$ axis. Nature 2019, 569, 229-235. [CrossRef] [PubMed]

339. Villarroya, F.; Cereijo, R.; Villarroya, J.; Giralt, M. Brown adipose tissue as a secretory organ. Nat. Publ. Gr. 2017, 13, 26. [CrossRef] [PubMed]

340. Rosell, M.; Hondares, E.; Iwamoto, S.; Gonzalez, F.J.; Wabitsch, M.; Staels, B.; Olmos, Y.; Monsalve, M.; Giralt, M.; Iglesias, R.; et al. Peroxisome Proliferator-Activated Receptors- $\alpha$ and $-\gamma$, and cAMP-Mediated Pathways, Control Retinol-Binding Protein- 4 Gene Expression in Brown Adipose Tissue. Endocrinology 2012, 153, 1162-1173. [CrossRef] [PubMed]

341. Yang, Q.; Graham, T.E.; Mody, N.; Preitner, F.; Peroni, O.D.; Zabolotny, J.M.; Kotani, K.; Quadro, L.; Kahn, B.B. Serum retinol binding protein 4 contributes to insulin resistance in obesity and type 2 diabetes. Nature 2005, 436, 356-362. [CrossRef] [PubMed]

342. Dominguez, L.J.; Barbagallo, M. The biology of the metabolic syndrome and aging. Curr. Opin. Clin. Nutr. Metab. Care 2016, 19, 5-11. [CrossRef]

343. Cañadas-Lozano, D.; Marín-Aguilar, F.; Castejón-Vega, B.; Ryffel, B.; Navarro-Pando, J.M.; Ruiz-Cabello, J.; Alcocer-Gómez, E.; Bullón, P.; Cordero, M.D. Blockade of the NLRP3 inflammasome improves metabolic health and lifespan in obese mice. GeroScience 2020, 42, 715-725. [CrossRef]

344. Di Angelantonio, E.; Bhupathiraju, S.N.; Wormser, D.; Gao, P.; Kaptoge, S.; de Gonzalez, A.B.; Cairns, B.J.; Huxley, R.; Jackson, C.L.; Joshy, G.; et al. Body-mass index and all-cause mortality: Individual-participant-data meta-analysis of 239 prospective studies in four continents. Lancet 2016, 388, 776-786. [CrossRef]

345. Jura, M.; Kozak, L.P. Obesity and related consequences to ageing. Age 2016, 38, 23. [CrossRef] [PubMed]

346. Tam, B.T.; Morais, J.A.; Santosa, S. Obesity and ageing: Two sides of the same coin. Obes. Rev. 2020, 21, e12991. [CrossRef] [PubMed]

347. Reis, F.C.G.; Branquinho, J.L.O.; Brandão, B.B.; Guerra, B.A.; Silva, I.D.; Frontini, A.; Thomou, T.; Sartini, L.; Cinti, S.; Ronald Kahn, C.; et al. Fat-specific Dicer deficiency accelerates aging and mitigates several effects of dietary restriction in mice. Aging (Albany. N. Y.) 2016, 8, 1201. [CrossRef]

348. Caron-Debarle, M.; Lagathu, C.; Boccara, F.; Vigouroux, C.; Capeau, J. HIV-associated lipodystrophy: From fat injury to premature aging. Trends Mol. Med. 2010, 16, 218-229. [CrossRef]

349. Chang, E.; Varghese, M.; Singer, K. Gender and Sex Differences in Adipose Tissue. Curr. Diab. Rep. 2018, 18, 1-10. [CrossRef]

350. Palmer, B.F.; Clegg, D.J. The sexual dimorphism of obesity. Mol. Cell. Endocrinol. 2015, 402, 113-119. [CrossRef]

351. Jespersen, N.; Andersen, M.; Jensen, V.; Stærkær, T.; Severinsen, M.; Peijs, L.; Soares, R.; Forss, I.; Andersen, E.; Hahn, C.; et al. Thermogenic genes are blunted whereas brown adipose tissue identity is preserved in human obesity. BioRxiv 2020. [CrossRef]

352. Link, J.C.; Chen, X.; Arnold, A.P.; Reue, K. Metabolic impact of sex chromosomes. Adipocyte 2013, 2, 74-79. [CrossRef] [PubMed]

353. Lemaître, J.F.; Ronget, V.; Tidière, M.; Allainé, D.; Berger, V.; Cohas, A.; Colchero, F.; Conde, D.A.; Garratt, M.; Liker, A.; et al. Sex differences in adult lifespan and aging rates of mortality across wild mammals. Proc. Natl. Acad. Sci. USA 2020, 117, 8546-8553. [CrossRef]

354. White, U.A.; Tchoukalova, Y.D. Sex dimorphism and depot differences in adipose tissue function. Biochim. Biophys. Acta Mol. Basis Dis. 2014, 1842, 377-392. [CrossRef]

355. Bloor, I.D.; Symonds, M.E. Sexual dimorphism in white and brown adipose tissue with obesity and inflammation. Horm. Behav. 2014, 66, 95-103. [CrossRef]

356. Balasubramanian, P.; Hall, D.; Subramanian, M. Sympathetic nervous system as a target for aging and obesity-related cardiovascular diseases. GeroScience 2019, 41, 13-24. [CrossRef] [PubMed]

357. Gaidhu, M.P.; Anthony, N.M.; Patel, P.; Hawke, T.J.; Ceddia, R.B. Dysregulation of lipolysis and lipid metabolism in visceral and subcutaneous adipocytes by high-fat diet: Role of ATGL, HSL and AMPK. Am. J. Physiol. Cell Physiol. 2010, 298, C961-C971. [CrossRef]

358. Smith, M.M.; Minson, C.T. Obesity and adipokines: Effects on sympathetic overactivity. J. Physiol. 2012, 590, 1787-1801. [CrossRef] 
359. Guarino, D.; Nannipieri, M.; Iervasi, G.; Taddei, S.; Bruno, R.M. The role of the autonomic nervous system in the pathophysiology of obesity. Front. Physiol. 2017, 8, 665. [CrossRef] [PubMed]

360. Feldstein, C.; Julius, S. The complex interaction between overweight, hypertension, and sympathetic overactivity. J. Am. Soc. Hypertens. 2009, 3, 353-365. [CrossRef]

361. Van Baak, M.A. The peripheral sympathetic nervous system in human obesity. Obes. Rev. 2001, 2, 3-14. [CrossRef]

362. Kotzbeck, P.; Giordano, A.; Mondini, E.; Murano, I.; Severi, I.; Venema, W.; Cecchini, M.P.; Kershaw, E.E.; Barbatelli, G.; Haemmerle, G.; et al. Brown adipose tissue whitening leads to brown adipocyte death and adipose tissue inflammation. J. Lipid Res. 2018, 59, 784-794. [CrossRef]

363. Hotamisligil, G.S. Endoplasmic Reticulum Stress and the Inflammatory Basis of Metabolic Disease. Cell 2010, $140,900-917$. [CrossRef] [PubMed]

364. Özcan, U.; Cao, Q.; Yilmaz, E.; Lee, A.H.; Iwakoshi, N.N.; Özdelen, E.; Tuncman, G.; Görgün, C.; Glimcher, L.H.; Hotamisligil, G.S. Endoplasmic reticulum stress links obesity, insulin action, and type 2 diabetes. Science 2004, 306, 457-461. [CrossRef] [PubMed]

365. Park, S.; Aintablian, A.; Coupe, B.; Bouret, S.G. The endoplasmic reticulum stress-autophagy pathway controls hypothalamic development and energy balance regulation in leptin-deficient neonates. Nat. Commun. 2020, 11, 1-11. [CrossRef]

366. Cnop, M.; Foufelle, F.; Velloso, L.A. Endoplasmic reticulum stress, obesity and diabetes. Trends Mol. Med. 2012, 18, 59-68. [CrossRef]

367. Xu, L.; Spinas, G.A.; Niessen, M. ER stress in adipocytes inhibits insulin signaling, represses lipolysis, and alters the secretion of adipokines without inhibiting glucose transport. Horm. Metab. Res. 2010, 42, 643-651. [CrossRef] [PubMed]

368. Lee, J.H.; Park, A.; Oh, K.J.; Lee, S.C.; Kim, W.K.; Bae, K.H. The role of adipose tissue mitochondria: Regulation of mitochondrial function for the treatment of metabolic diseases. Int. J. Mol. Sci. 2019, 20, 4924. [CrossRef] [PubMed]

369. Altshuler-Keylin, S.; Kajimura, S. Mitochondrial homeostasis in adipose tissue remodeling. Sci. Signal. 2017, 10. [CrossRef]

370. Gao, A.W.; Houtkooper, R.H. Mitochondrial fission: Firing up mitochondria in brown adipose tissue. EMBO J. $2014,33,401-402$. [CrossRef]

371. Lu, X.; Altshuler-Keylin, S.; Wang, Q.; Chen, Y.; Sponton, C.H.; Ikeda, K.; Maretich, P.; Yoneshiro, T.; Kajimura, S. Mitophagy controls beige adipocyte maintenance through a Parkin-dependent and UCP1-independent mechanism. Sci. Signal. 2018, 11 [CrossRef]

372. Rabiee, A. Beige Fat Maintenance; Toward a Sustained Metabolic Health. Front. Endocrinol. 2020, 11, 634. [CrossRef] [PubMed]

373. Kusminski, C.M.; Scherer, P.E. Mitochondrial dysfunction in white adipose tissue. Trends Endocrinol. Metab. 2012, 23, 435-443. [CrossRef] [PubMed]

374. Woo, C.Y.; Jang, J.E.; Lee, S.E.; Koh, E.H.; Lee, K.U. Mitochondrial dysfunction in adipocytes as a primary cause of adipose tissue inflammation. Diabetes Metab. J. 2019, 43, 247. [CrossRef] [PubMed]

375. Ejarque, M.; Ceperuelo-Mallafré, V.; Serena, C.; Maymo-Masip, E.; Duran, X.; Díaz-Ramos, A.; Millan-Scheiding, M.; Núñez-Álvarez, Y.; Núñez-Roa, C.; Gama, P.; et al. Adipose tissue mitochondrial dysfunction in human obesity is linked to a specific DNA methylation signature in adipose-derived stem cells. Int. J. Obes. 2019, 43, 1256-1268. [CrossRef]

376. Perera, U.; Kennedy, B.A.; Hegele, R.A. Multiple Symmetric Lipomatosis (Madelung Disease) in a Large Canadian Family With the Mitochondrial MTTK c.8344A>G Variant. J. Investig. Med. High. Impact Case Rep. 2018, 6. [CrossRef]

377. Capel, E.; Vatier, C.; Cervera, P.; Stojkovic, T.; Disse, E.; Cottereau, A.S.; Auclair, M.; Verpont, M.C.; Mosbah, H.; Gourdy, P.; et al. MFN2-associated lipomatosis: Clinical spectrum and impact on adipose tissue. J. Clin. Lipidol. 2018, 12, 1420-1435. [CrossRef] [PubMed]

378. Reilly, S.M.; Saltiel, A.R. Adapting to obesity with adipose tissue inflammation. Nat. Rev. Endocrinol. 2017, 13, 633. [CrossRef] [PubMed]

379. Blüher, M. Adipose tissue inflammation: A cause or consequence of obesity-related insulin resistance? Clin. Sci. 2016, 130, 1603-1614. [CrossRef]

380. Hotamisligil, G.S.; Shargill, N.S.; Spiegelman, B.M. Adipose expression of tumor necrosis factor- $\alpha$ : Direct role in obesity-linked insulin resistance. Science 1993, 259, 87-91. [CrossRef]

381. Lumeng, C.N.; Delproposto, J.B.; Westcott, D.J.; Saltiel, A.R. Phenotypic switching of adipose tissue macrophages with obesity is generated by spatiotemporal differences in macrophage subtypes. Diabetes 2008, 57, 3239-3246. [CrossRef]

382. Nishimura, S.; Manabe, I.; Nagasaki, M.; Eto, K.; Yamashita, H.; Ohsugi, M.; Otsu, M.; Hara, K.; Ueki, K.; Sugiura, S.; et al. CD8+ effector T cells contribute to macrophage recruitment and adipose tissue inflammation in obesity. Nat. Med. 2009, 15, 914-920. [CrossRef] [PubMed]

383. Winer, D.A.; Winer, S.; Shen, L.; Wadia, P.P.; Yantha, J.; Paltser, G.; Tsui, H.; Wu, P.; Davidson, M.G.; Alonso, M.N.; et al. B cells promote insulin resistance through modulation of T cells and production of pathogenic IgG antibodies. Nat. Med. 2011, 17, 610-617. [CrossRef]

384. Wu, D.; Molofsky, A.B.; Liang, H.E.; Ricardo-Gonzalez, R.R.; Jouihan, H.A.; Bando, J.K.; Chawla, A.; Locksley, R.M. Eosinophils sustain adipose alternatively activated macrophages associated with glucose homeostasis. Science 2011, 332, 243-247. [CrossRef]

385. Lumeng, C.N.; Liu, J.; Geletka, L.; Delaney, C.; Delproposto, J.; Desai, A.; Oatmen, K.; Martinez-Santibanez, G.; Julius, A.; Garg, S.; et al. Aging Is Associated with an Increase in T Cells and Inflammatory Macrophages in Visceral Adipose Tissue. J. Immunol. 2011, 187, 6208-6216. [CrossRef] 
386. Kahn, C.R.; Wang, G.; Lee, K.Y. Altered adipose tissue and adipocyte function in the pathogenesis of metabolic syndrome. J. Clin. Investig. 2019, 129, 3990-4000. [CrossRef]

387. Glass, C.K.; Olefsky, J.M. Inflammation and lipid signaling in the etiology of insulin resistance. Cell Metab. 2012, 15, 635-645. [CrossRef] [PubMed]

388. Feinstein, R.; Kanety, H.; Papa, M.Z.; Lunenfeld, B.; Karasik, A. Tumor necrosis factor- $\alpha$ suppresses insulin-induced tyrosine phosphorylation of insulin receptor and its substrates. J. Biol. Chem. 1993, 268, 26055-26058. [CrossRef]

389. Müller, T.D.; Clemmensen, C.; Finan, B.; Dimarchi, R.D.; Tschöp, M.H. Anti-obesity therapy: From rainbow pills to polyagonists. Pharmacol. Rev. 2018, 70, 712-746. [CrossRef]

390. Coulter, A.A.; Rebello, C.J.; Greenway, F.L. Centrally Acting Agents for Obesity: Past, Present, and Future. Drugs 2018, 78, 1113-1132. [CrossRef] [PubMed]

391. Hanssen, M.J.W.; Hoeks, J.; Brans, B.; Van Der Lans, A.A.J.J.; Schaart, G.; Van Den Driessche, J.J.; Jörgensen, J.A.; Boekschoten, M.V.; Hesselink, M.K.C.; Havekes, B.; et al. Short-term cold acclimation improves insulin sensitivity in patients with type 2 diabetes mellitus. Nat. Med. 2015, 21, 863-865. [CrossRef]

392. Yoneshiro, T.; Aita, S.; Matsushita, M.; Kayahara, T.; Kameya, T.; Kawai, Y.; Iwanaga, T.; Saito, M. Recruited brown adipose tissue as an antiobesity agent in humans. J. Clin. Investig. 2013, 123, 3404-3408. [CrossRef] [PubMed]

393. Ameka, M.; Markan, K.R.; Morgan, D.A.; BonDurant, L.D.; Idiga, S.O.; Naber, M.C.; Zhu, Z.; Zingman, L.V.; Grobe, J.L.; Rahmouni, K.; et al. Liver Derived FGF21 Maintains Core Body Temperature During Acute Cold Exposure. Sci. Rep. 2019, 9, 630. [CrossRef] [PubMed]

394. Chartoumpekis, D.V.; Habeos, I.G.; Ziros, P.G.; Psyrogiannis, A.I.; Kyriazopoulou, V.E.; Papavassiliou, A.G. Brown adipose tissue responds to cold and adrenergic stimulation by induction of FGF21. Mol. Med. 2011, 17, 736-740. [CrossRef] [PubMed]

395. Huang, Z.; Zhong, L.; Lee, J.T.H.; Zhang, J.; Wu, D.; Geng, L.; Wang, Y.; Wong, C.M.; Xu, A. The FGF21-CCL11 Axis Mediates Beiging of White Adipose Tissues by Coupling Sympathetic Nervous System to Type 2 Immunity. Cell Metab. 2017, 26, 493-508. [CrossRef] [PubMed]

396. BonDurant, L.D.; Ameka, M.; Naber, M.C.; Markan, K.R.; Idiga, S.O.; Acevedo, M.R.; Walsh, S.A.; Ornitz, D.M.; Potthoff, M.J. FGF21 Regulates Metabolism Through Adipose-Dependent and -Independent Mechanisms. Cell Metab. 2017, 25, 935-944. [CrossRef] [PubMed]

397. Hanssen, M.J.W.; Broeders, E.; Samms, R.J.; Vosselman, M.J.; Van Der Lans, A.A.J.J.; Cheng, C.C.; Adams, A.C.; Van Marken Lichtenbelt, W.D.; Schrauwen, P. Serum FGF21 levels are associated with brown adipose tissue activity in humans. Sci. Rep. 2015, 5, 1-8. [CrossRef]

398. Bina, H.A.; Kharitonenkov, A.; Antonellis, P.J.; Flier, J.S.; Maratos-Flier, E.; Fisher, F.M.; Chui, P.C.; Lin, Z.; Tian, H.; Lam, K.S.S.L.L.; et al. FGF21 acts centrally to induce sympathetic nerve activity, energy expenditure, and weight loss. Cell Metab. 2008, 20, 670-677.

399. Shamsi, F.; Xue, R.; Huang, T.L.; Lundh, M.; Liu, Y.; Leiria, L.O.; Lynes, M.D.; Kempf, E.; Wang, C.H.; Sugimoto, S.; et al. FGF6 and FGF9 regulate UCP1 expression independent of brown adipogenesis. Nat. Commun. 2020, 11, 1-16. [CrossRef]

400. Bank, H.V.; Hurtado-Thiele, M.; Oshimura, N.; Simcox, J. Mitochondrial Lipid Signaling and Adaptive Thermogenesis. Metabolites 2021, 11, 124. [CrossRef]

401. Xu, L.; Zhao, W.; Wang, D.; Ma, X. Chinese medicine in the battle against obesity and metabolic diseases. Front. Physiol. 2018, 9, 850. [CrossRef]

402. Yin, J.; Xing, H.; Ye, J. Efficacy of berberine in patients with type 2 diabetes mellitus. Metabolism 2008, 57, 712-717. [CrossRef]

403. Xu, X.; Yi, H.; Wu, J.; Kuang, T.; Zhang, J.; Li, Q.; Du, H.; Xu, T.; Jiang, G.; Fan, G. Therapeutic effect of berberine on metabolic diseases: Both pharmacological data and clinical evidence. Biomed. Pharmacother. 2021, 133, 110984. [CrossRef]

404. Zhang, Z.; Zhang, H.; Li, B.; Meng, X.; Wang, J.; Zhang, Y.; Yao, S.; Ma, Q.; Jin, L.; Yang, J.; et al. Berberine activates thermogenesis in white and brown adipose tissue. Nat. Commun. 2014, 5, 1-15. [CrossRef]

405. Wu, L.; Xia, M.; Duan, Y.; Zhang, L.; Jiang, H.; Hu, X.; Yan, H.; Zhang, Y.; Gu, Y.; Shi, H.; et al. Berberine promotes the recruitment and activation of brown adipose tissue in mice and humans. Cell Death Dis. 2019, 10,1-18. [CrossRef]

406. El Hadi, H.; Di Vincenzo, A.; Vettor, R.; Rossato, M. Food ingredients involved in white-to-brown adipose tissue conversion and in calorie burning. Front. Physiol. 2019, 10, 1954. [CrossRef] [PubMed]

407. Ohyama, K.; Nogusa, Y.; Shinoda, K.; Suzuki, K.; Bannai, M.; Kajimura, S. A synergistic antiobesity effect by a combination of capsinoids and cold temperature through promoting beige adipocyte biogenesis. Diabetes 2016, 65, 1410-1423. [CrossRef] [PubMed]

408. Hewlings, S.; Kalman, D. Curcumin: A Review of Its Effects on Human Health. Foods 2017, 6, 92. [CrossRef] [PubMed]

409. Akbari, M.; Lankarani, K.B.; Tabrizi, R.; Ghayour-Mobarhan, M.; Peymani, P.; Ferns, G.; Ghaderi, A.; Asemi, Z. The effects of curcumin on weight loss among patients with metabolic syndrome and related disorders: A systematic review and meta-analysis of randomized controlled trials. Front. Pharmacol. 2019, 10, 649. [CrossRef]

410. Lone, J.; Choi, J.H.; Kim, S.W.; Yun, J.W. Curcumin induces brown fat-like phenotype in 3T3-L1 and primary white adipocytes. J. Nutr. Biochem. 2016, 27, 193-202. [CrossRef]

411. Wang, S.; Wang, X.; Ye, Z.; Xu, C.; Zhang, M.; Ruan, B.; Wei, M.; Jiang, Y.; Zhang, Y.; Wang, L.; et al. Curcumin promotes browning of white adipose tissue in a norepinephrine-dependent way. Biochem. Biophys. Res. Commun. 2015, 466, 247-253. [CrossRef] 
412. Ejaz, A.; Wu, D.; Kwan, P.; Meydani, M. Curcumin inhibits adipogenesis in 3T3-L1 adipocytes and angiogenesis and obesity in C57/BL mice. J. Nutr. 2009, 139, 919-925. [CrossRef] [PubMed]

413. Okla, M.; Kim, J.; Koehler, K.; Chungn, S. Dietary factors promoting brown and beige fat development and thermogenesis. Adv. Nutr. 2017, 8, 473-483. [CrossRef]

414. Kajimoto, O.; Kajimoto, Y.; Yabune, M.; Nakamura, T.; Kotani, K.; Suzuki, Y.; Nozawa, A.; Nagata, K.; Unno, T.; Yuko, M.S.; et al. Tea catechins with a galloyl moiety reduce body weight and fat. J. Heal. Sci. 2005, 51, 161-171. [CrossRef]

415. Wolfram, S.; Wang, Y.; Thielecke, F. Anti-obesity effects of green tea: From bedside to bench. Mol. Nutr. Food Res. 2006, 50, 176-187. [CrossRef]

416. Zhang, Y.; Yu, Y.; Li, X.; Meguro, S.; Hayashi, S.; Katashima, M.; Yasumasu, T.; Wang, J.; Li, K. Effects of catechin-enriched green tea beverage on visceral fat loss in adults with a high proportion of visceral fat: A double-blind, placebo-controlled, randomized trial. J. Funct. Foods 2012, 4, 315-322. [CrossRef]

417. Neyrinck, A.M.; Bindels, L.B.; Geurts, L.; Van Hul, M.; Cani, P.D.; Delzenne, N.M. A polyphenolic extract from green tea leaves activates fat browning in high-fat-diet-induced obese mice. J. Nutr. Biochem. 2017, 49, 15-21. [CrossRef]

418. Dulloo, A.G.; Duret, C.; Rohrer, D.; Girardier, L.; Mensi, N.; Fathi, M.; Chantre, P.; Vandermander, J. Efficacy of a green tea extract rich in catechin polyphenols and caffeine in increasing 24-h energy expenditure and fat oxidation in humans. Am. J. Clin. Nutr. 1999, 70, 1040-1045. [CrossRef] [PubMed]

419. Salehi, B.; Mishra, A.P.; Nigam, M.; Sener, B.; Kilic, M.; Sharifi-Rad, M.; Fokou, P.V.T.; Martins, N.; Sharifi-Rad, J. Resveratrol: A double-edged sword in health benefits. Biomedicines 2018, 6, 91. [CrossRef]

420. Lagouge, M.; Argmann, C.; Gerhart-Hines, Z.; Meziane, H.; Lerin, C.; Daussin, F.; Messadeq, N.; Milne, J.; Lambert, P.; Elliott, P.; et al. Resveratrol Improves Mitochondrial Function and Protects against Metabolic Disease by Activating SIRT1 and PGC-1 $\alpha$. Cell 2006, 127, 1109-1122. [CrossRef] [PubMed]

421. Fischer-Posovszky, P.; Kukulus, V.; Tews, D.; Unterkircher, T.; Debatin, K.M.; Fulda, S.; Wabitsch, M. Resveratrol regulates human adipocyte number and function in a Sirt1-dependent manner. Am. J. Clin. Nutr. 2010, 127, 1109-1122. [CrossRef]

422. Wang, S.; Liang, X.; Yang, Q.; Fu, X.; Rogers, C.J.; Zhu, M.; Rodgers, B.D.; Jiang, Q.; Dodson, M.V.; Du, M. Resveratrol induces brown-like adipocyte formation in white fat through activation of AMP-activated protein kinase (AMPK) $\alpha 1$. Int. J. Obes. 2015, 39, 967-976. [CrossRef] [PubMed]

423. Timmers, S.; Konings, E.; Bilet, L.; Houtkooper, R.H.; Van De Weijer, T.; Goossens, G.H.; Hoeks, J.; Van Der Krieken, S.; Ryu, D.; Kersten, S.; et al. Calorie restriction-like effects of 30 days of resveratrol supplementation on energy metabolism and metabolic profile in obese humans. Cell Metab. 2011, 14, 612-622. [CrossRef]

424. Yoshida, T.; Sakane, N.; Wakabayashi, Y.; Umekawa, T.; Kondo, M. Anti-obesity and anti-diabetic effects of CL 316, 243, a highly specific $\beta 3$-adrenoceptor agonist, in yellow KK mice. Life Sci. 1994, 54, 491-498. [CrossRef]

425. Xiao, C.; Goldgof, M.; Gavrilova, O.; Reitman, M.L. Anti-obesity and metabolic efficacy of the $\beta 3$-adrenergic agonist, CL316243, in mice at thermoneutrality compared to $22^{\circ} \mathrm{C}$. Obesity 2015, 23, 1450-1459. [CrossRef]

426. Inokuma, K.I.; Okamatsu-Ogura, Y.; Omachi, A.; Matsushita, Y.; Kimura, K.; Yamashita, H.; Saito, M. Indispensable role of mitochondrial UCP1 for antiobesity effect of $\beta 3$-adrenergic stimulation. Am. J. Physiol. Endocrinol. Metab. 2006, 290 , E1014-E1021. [CrossRef]

427. Arch, J.R.S. Challenges in $\beta 3$-adrenoceptor agonist drug development. Ther. Adv. Endocrinol. Metab. 2011. [CrossRef]

428. Clapham, J.C.; Arch, J.R.S. Thermogenic and metabolic antiobesity drugs: Rationale and opportunities. Diabetes Obes. Metab. 2007, 9, 259-275. [CrossRef] [PubMed]

429. Baskin, A.S.; Linderman, J.D.; Brychta, R.J.; McGehee, S.; Anflick-Chames, E.; Cero, C.; Johnson, J.W.; O’Mara, A.E.; Fletcher, L.A.; Leitner, B.P.; et al. Regulation of human adipose tissue activation, gallbladder size, and bile acid metabolism by A b3-adrenergic receptor agonist. Diabetes 2018, 67, 2113-2125. [CrossRef]

430. Finlin, B.S.; Memetimin, H.; Zhu, B.; Confides, A.L.; Vekaria, H.J.; El Khouli, R.H.; Johnson, Z.R.; Westgate, P.M.; Chen, J.; Morris, A.J.; et al. The $\beta 3$-adrenergic receptor agonist mirabegron improves glucose homeostasis in obese humans. J. Clin. Investig. 2020, 130. [CrossRef] [PubMed]

431. Blondin, D.P.; Nielsen, S.; Kuipers, E.N.; Severinsen, M.C.; Jensen, V.H.; Miard, S.; Jespersen, N.Z.; Kooijman, S.; Boon, M.R.; Fortin, M.; et al. Human Brown Adipocyte Thermogenesis Is Driven by ß2-AR Stimulation. Cell Metab. 2020, 32, 287-300. [CrossRef] [PubMed]

432. González-García, I.; Milbank, E.; Diéguez, C.; López, M.; Contreras, C. Glucagon, GLP-1 and thermogenesis. Int. J. Mol. Sci. 2019, 20, 3445. [CrossRef]

433. Lockie, S.H.; Heppner, K.M.; Chaudhary, N.; Chabenne, J.R.; Morgan, D.A.; Veyrat-Durebex, C.; Ananthakrishnan, G.; Rohner-Jeanrenaud, F.; Drucker, D.J.; DiMarchi, R.; et al. Direct control of brown adipose tissue thermogenesis by central nervous system glucagon-like peptide-1 receptor signaling. Diabetes 2012, 61, 2753-2762. [CrossRef] [PubMed]

434. López, M.; Diéguez, C.; Nogueiras, R. Hypothalamic GLP-1: The control of BAT thermogenesis and browning of white fat. Adipocyte 2015, 4, 141-145. [CrossRef]

435. Beiroa, D.; Imbernon, M.; Gallego, R.; Senra, A.; Herranz, D.; Villarroya, F.; Serrano, M.; Fernø, J.; Salvador, J.; Escalada, J.; et al. GLP-1 agonism stimulates brown adipose tissue thermogenesis and browning through hypothalamic AMPK. Diabetes 2014, 63, 3346-3358. [CrossRef] 
436. Goswami, R.; Subramanian, G.; Silayeva, L.; Newkirk, I.; Doctor, D.; Chawla, K.; Chattopadhyay, S.; Chandra, D.; Chilukuri, N.; Betapudi, V. Gene therapy leaves a vicious cycle. Front. Oncol. 2019, 9, 297. [CrossRef]

437. Samuelson, I.; Vidal-Puig, A. Studying Brown Adipose Tissue in a Human in vitro Context. Front. Endocrinol. 2020, 11, 629. [CrossRef] [PubMed]

438. Chen, Y.; Liu, Y.; Zhang, J.; Liu, H.; Wang, J.; Liu, Q.; Zhang, Y. Three-dimensional bioprinting adipose tissue and mammary Organoids feasible for artificial breast structure regeneration. Mater. Des. 2021. [CrossRef] 